University of Rhode Island

DigitalCommons@URI

Open Access Master's Theses

1991

\title{
COMMERCIAL REVITALIZATION GUIDELINES FOR BROAD STREET, PROVIDENCE, RHODE ISIAND
}

Kathleen A. Barton

University of Rhode Island

Pao Charles Kue

University of Rhode Island

Follow this and additional works at: https://digitalcommons.uri.edu/theses

\section{Recommended Citation}

Barton, Kathleen A. and Kue, Pao Charles, "COMMERCIAL REVITALIZATION GUIDELINES FOR BROAD STREET, PROVIDENCE, RHODE ISIAND" (1991). Open Access Master's Theses. Paper 561.

https://digitalcommons.uri.edu/theses/561

This Thesis is brought to you for free and open access by DigitalCommons@URI. It has been accepted for inclusion in Open Access Master's Theses by an authorized administrator of DigitalCommons@URI. For more information, please contact digitalcommons-group@uri.edu. 


\title{
COMMERCIAL REVITALIZATION \\ GUIDELINES FOR BROAD STREET, PROVIDENCE, RHODE ISLAND
}

BY

KATHLEEN A. BARTON

PAO CHARLES KUE

\author{
A RESEARCH PROJECT SUBMITTED IN \\ PARTIAL FULFILLMENT OF THE REQUIREMENTS \\ FOR THE DEGREE OF \\ MASTER OF COMMUNITY PLANNING
}

UNIVERSITY OF RHODE ISLAND

1991 


\section{ACKNOWLEDGEMENTS}

We would both like to thank Franco Beneduce, whose enthusiasm and concern for the Broad Street Commercial District played an important factor in the development of this project. We would also like to thank Dr. Farhad Atash, our faculty advisor, whose guidance was greatly appreciated.

K.A.B. - I would like to thank all of the members of my family, whose love and support have been a great source of comfort and strength to me as I attempted to complete my education. I would also like to thank my best friend and classmate, Huaqi Yuan, who has taught me about the importance of friendship, a lesson I will always remember. In addition, I would like to thank Charles for working with me on this project.

P.C.K. - I would like to thank my parents and the Kue Clan for their support, wisdom, and encouragement. I would also like thank my wife for her patience and emotional support over the past four semesters. Finally, I would like to thank Kathleen for her expertise and inspiration. Without her this project would not have been successful. 
ACKNOWLEDEGEMENTS $\ldots \ldots \ldots \ldots \ldots \ldots \ldots \ldots \ldots \ldots$ i

TABLE OF CONTENTS $\ldots \ldots \ldots \ldots \ldots \ldots \ldots \ldots \ldots \ldots \ldots \ldots$ ii

LIST OF FIGURES $\ldots \ldots \ldots \ldots \ldots \ldots \ldots \ldots \ldots \ldots \ldots$ iv

LIST OF TABLES $\ldots \ldots \ldots \ldots \ldots \ldots \ldots \ldots \ldots \ldots \ldots \ldots \ldots \ldots$

I. CHAPTER ONE - INTRODUCTION $\ldots \ldots \ldots \ldots \ldots \ldots \ldots \ldots \ldots 2$

PROBLEM STATEMENT $\ldots \ldots \ldots \ldots \ldots \ldots \ldots \ldots \ldots$

THE ROLE OF ELMWOOD NEIGHBORHOOD

HOUSING SERVICES . ................... 5

PROCEDURES AND METHODS OF ANALYSIS $\ldots \ldots \ldots \ldots \ldots 6$

OVERVIEW OF LITERATURE $\ldots \ldots \ldots \ldots \ldots \ldots \ldots \ldots$

II. CHAPTER TWO - HISTORICAL AND DEMOGRAPHIC ANALYSIS . . 12 LOCATION OF THE STUDY AREA $\ldots \ldots \ldots \ldots \ldots \ldots \ldots 12$

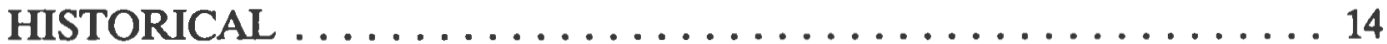

DEMOGRAPHIC ANALYSIS $\ldots \ldots \ldots \ldots \ldots \ldots \ldots \ldots \ldots$

SUMMARY OF FINDINGS $\ldots \ldots \ldots \ldots \ldots \ldots \ldots \ldots \ldots \ldots$

III. CHAPTER THREE - INVENTORY OF EXISTING CONDITIONS 32

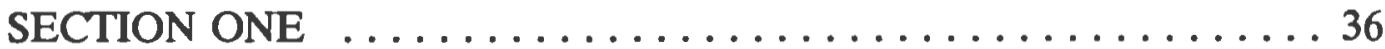

SECTION TWO ...................... 41

SECTION THREE ...................... 45

SECTION FOUR .....................49

SUMMARY OF FINDINGS $\ldots \ldots \ldots \ldots \ldots \ldots \ldots \ldots \ldots 2$

IV. CHAPTER FOUR - REVIEW OF PLANNING DOCUMENTS $\ldots \ldots 55$

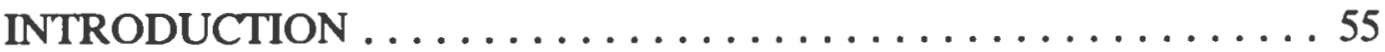

THE MOUNT PLEASANT BUSINESS DISTRICT

REVITALIZATION PLAN-1990 . . . . . . . . . . . . . . 56

DEPASQUALE AVENUE-FEDERAL STREET TARGET

AREA - $1989 \ldots \ldots \ldots \ldots \ldots \ldots \ldots \ldots \ldots \ldots \ldots \ldots \ldots \ldots \ldots \ldots$

UPPER SOUTH PROVIDENCE PROPOSED

REDEVELOPMENT PLAN $-1984 \ldots \ldots \ldots \ldots \ldots \ldots \ldots \ldots \ldots 65$

V. CHAPTER FIVE - REVITALIZATION GUIDELINES $\ldots \ldots \ldots \ldots 75$

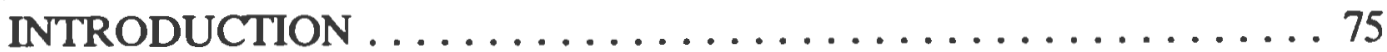

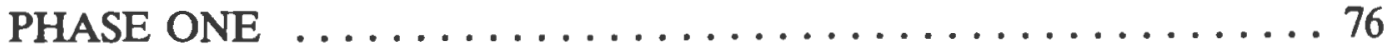

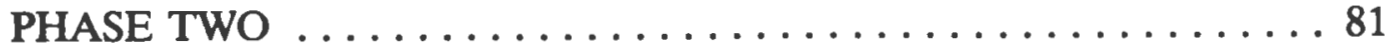

PHASE THREE ........................ 87

PHASE FOUR $\ldots \ldots \ldots \ldots \ldots \ldots \ldots \ldots \ldots \ldots \ldots \ldots$ 
VI. REFERENCES $\ldots \ldots \ldots \ldots \ldots \ldots \ldots \ldots \ldots \ldots \ldots \ldots \ldots$

VII. APPENDICES $\ldots \ldots \ldots \ldots \ldots \ldots \ldots \ldots \ldots \ldots \ldots \ldots \ldots \ldots \ldots$ 


\section{LIST OF FIGURES}

PAGE

1. Neighborhood map of Providence 13

2. Historical map of Providence 16

3. Historical maps of Providence during the 1800's 17

4. Census tracts of Providence 20

5. Neighborhood map 27

6. Zoning map $\quad 35$

7. Map of Section One 37

8. Map of Section Two 42

9. Map of Section Three 46

10. Map of Section Four 50 


\section{LIST OF TABLES}

$\underline{\text { PAGE }}$

1. Inventory of Broad Street Businesses 1991

2. 1980 Census 21

3. Adjusted 1989 Census 22

4. Projected 1994 Census 23

5. Inventory of Section One 38

6. Inventory of Section Two 43

7. Inventory of Section Three 47

8. Inventory of Section Four 49 
CHAPTER ONE

INTRODUCTION 
Throughout the 1980's several neighborhoods within the City of Providence, Rhode Island have been undergoing a rapid rate of economic and physical decline. The Elmwood, Upper and Lower South Providence neighborhoods, in particular, have been faced with several difficulties in this regard. Currently, this area is experiencing high crime rates and several businesses located along the commercial area of Broad Street have been vacated due to economic hardships caused by low customer volumes.

Elmwood Neighborhood Housing Services, Inc.(ENHS), a non-profit organization which is located within this area, has expressed a growing concern for improving the Broad Street section of its neighborhood. It is the hope of ENHS that by addressing the issue of the commercial revitalization of Broad Street that these efforts will result in the spread of economic revitalization and physical improvements throughout the neighborhoods which border it.

Currently, ENHS is considering two strategies in order to achieve this goal. The first strategy would be to develop an urban design guideline for Broad Street, a project to be undertaken by students at the Rhode Island School of Design. Second, is a set of commercial revitalization guidelines which will be the focus of this project.

This document has been developed by Kathleen Barton and Pao Charles Kue for ENHS and its Commercial Coordinator, Franco Beneduce. Its major goal is to assist in the development of Commercial Revitalization Guidelines for the Broad Street Commercial District which will meet the criteria of ENHS and its surrounding 
neighborhoods while following redevelopment procedures of the City of Providence's Department of Planning and Development.

The major objective of this project will be to develop a guideline for ENHS to use in an effort to develop a plan which will stimulate commercial development within the Broad Street area. Three objectives which will be used in the development of this guideline are:

1. To retain existing businesses;

2. To help existing businesses expand or improve their condition; and

3. To attract new commercial activity to the area

In the process of developing this guideline, it will also be necessary to examine Broad Street and its current role in the City from both economic and governmental aspects. By focusing on City and State guidelines for redevelopment the issue of how a commercial redevelopment plan can be achieved through the formal governmental process will be addressed.

\section{Problem Statement}

The area which borders Broad Street is considered one of the poorest in the city. Its image is that of a dangerous area where there is heavy drug traffic and high levels of illegal activity. Many properties have been abandoned or are owned by absentee landlords who have left these properties unattended, resulting in buildings 
being in need of major repairs.

At the same time Broad Street has a wide range of ethnic restaurants and small specialty food stores which are mainly used by local residents. In addition, many of the homes located in the area have been built in the Victorian style. These are unique within the City itself. Sections of Elmwood and Lower and Upper South Providence have also been designated as Historic Districts and some of these buildings are also on the National Register of Historic Buildings.

A revitalization plan for Broad Street is a project which should make a meaningful contribution to the community if successfully implemented. It is the hope of ENHS that the development of a commercial revitalization plan for Broad Street will encourage the City, and its residents, to develop a renewed interest and pride in their neighborhood. By capitalizing on the ethnic diversity of the area and publicizing it as a section which is undergoing revitalization, the expected outcome is that new businesses and customers will be attracted to Broad Street and the surrounding neighborhoods.

This document will describe the Broad Street Commercial District and its surrounding neighborhoods. It will also analyze revitalization reports which have been produced by the City of Providence and discuss the specific needs of a revitalization plan for the Broad Street Commercial District. Finally, it will present a series of guidelines for the development of a revitalization plan. 


\section{The Role of Elmwood Neighborhood Housing Services}

Elmwood Neighborhood Housing Services is a non-profit organization which is part of the National Neighborworks Network. They have been active in the Elmwood neighborhood of Providence since 1978. While their original focus was on assisting local neighborhood residents to renovate their housing, they have recently directed their efforts toward commercial revitalization within the Broad Street Commercial District.

In 1990 ENHS appointed a Commercial Coordinator who has been actively trying to encourage interest in commercial development for the Broad Street Area. Included in theses efforts are anti graffiti and clean up campaigns which have been highly successful.

ENHS has also enlisted technical assistance from three local colleges. The University of Rhode Island is providing planing assistance through the production of this document. Rhode Island School of Design is devising a set of Urban Design guidelines. Finally, the Community College of Rhode Island is providing small business development assistance and guidance.

The most recent success of ENHS has been the establishment of a commercial revolving loan fund for Broad Street business owners. This fund is co-sponsored by the Neighborhood Reinvestment Corporations and the City of Providence. Both provide matching funds for improvements and renovations of local businesses.

The involvement of ENHS within the community has provided a renewed interest in the local neighborhoods and the Broad Street business district. Hopefully 
this interest will continue to develop and result in the revitalization of local businesses.

\section{Procedures and Methods of Analysis}

In order to develop a set of revitalization guidelines for the Broad Street Commercial District, it was necessary to utilize a series of procedures and methods of analysis which will be included in the remainder of this document. The methods of analysis used were as follows:

- Review of relevant revitalization and commercial redevelopment literature.

There is a wide variety of literature available on the subject of commercial revitalization. A brief review of the literature used for this document will be included in Chapter One and referred to throughout the remainder of it. A bibliography is also included at the end of the document.

\section{- Analysis of existing conditions}

In order to provide an accurate description of Broad Street it was necessary to analyze the area and its surrounding neighborhoods. This analysis was performed by utilizing various sources of information which included the following:

- Historical information

- Census Data

- Physical Inventory of Broad Street

- Zoning Maps 


\section{- Photographs}

The purpose of Chapter Two will be to describe the study area and how it has developed over the years. Included will be a brief history of Broad Street and its surrounding neighborhoods. Also,this chapter will include a demographic analysis of the five census tracts which border the Broad Street Commercial District.

Chapter Three will consist of a description of the current condition of businesses which are in existence along Broad Street. This chapter will focus on the separation of Broad Street into four sections. Each section will be described in reference to its businesses and their location within the section, the current condition of their facades, availability of parking, and existing zoning.

\section{- Previously published revitalization reports}

A series of revitalization plans have been produced by the Providence Redevelopment Agency and the Providence Department of Planning and Development over the years. Some of these reports, and their contents, will be discussed in Chapter Four along with issues which should be addressed in the commercial revitalization guidelines for the Broad Street Commercial District. Also included will be enabling legislation pertaining to the development and adoption of revitalization plans for the City of Providence.

\section{- Interviews}

In order to provide data which may not have been included in documents 
pertaining to revitalization within the Broad Street Commercial District, a series of individuals were interviewed. Each of the interviews was used to help identify some of the issues and concerns to be addressed in the development of revitalization guidelines. Information from these interviews will be included at various points throughout the document.

\section{Overview of literature}

In order to develop an understanding of the commercial revitalization process, it was necessary to review a series of articles and texts which pertain to this subject (See Bibliography). Each expressed a concern for the economic downturn of inner city commercial districts which has been occurring at a rapid rate (Barringer and Roche, 1987a, 1987b; Launce, 1985; Schwartz, 1984).

A major force which has effected the commercial districts in many cities, especially in the Northeast Region of the United States, is a change in the economic structuring of this country from the manufacturing industry to service industry (Schwartz,1984:45). Many cities, including Providence, have been affected by this trend.

A second reason for the decline of the commercial business district is the movement of businesses outward to the suburbs. Barringer and Roche (1987a:3) surmise that the reason for this trend is that relocation to the suburbs is often more lucrative than remaining in the inner city. Since the customers who are willing and able to spend more of their income have relocated to the suburbs, businesses find it 
necessary to follow their customers in order to survive. The result of this decline has been high vacancy rates,

deterioration of buildings and a general development of an unsafe quality to the commercial area itself.

Recently, many communities have been attempting to revitalize their commercial business districts. Barringer and Roche (1987a) point out that over $70 \%$ of the communities which are involved with local NHS organizations are, or have already, formulated plans for increasing economic development within their commercial districts. The driving force behind these efforts is, of course, local neighborhood residents. Rohe and Gates (1985) point out that, from a planning perspective, there are several advantages to utilizing neighborhood groups. First, neighborhood residents are often more familiar with the issues that are important to their neighborhoods. They know what is needed in their communities, and their involvement in the planning process is often beneficial in establishing goals and objectives for projects.

According to Rohe and Gates (1985:57), residents who are involved in the development of plans also gain a better understanding of the planning process. Often they become more aware of the difficulties that their cities and towns are facing other than the issues that pertain only to them. This interest in planning often develops into a better relationship between the citizens and local government.

Given this information, it was felt that developing guidelines for a commercial 
revitalization plan for the Broad Street Commercial District would be the best approach. This strategy would encourage the neighborhoods to become more aware of the planning process, and by doing so, develop a plan which best suits their needs. The Providence Department of Planning and Development will also benefit by having the opportunity to work with the community to develop a more implementable plan when compared to previous plans. 
CHAPTER TWO

HISTORY AND DEMOGRAPHIC

ANALYSIS 


\section{Introduction}

The purpose of this chapter is to describe the location and formation of the Broad Street Commercial District. Also included, is a demographic analysis of the area's bordering neighborhoods as each is divided into census tracts. Information for this section will give a general demographic profile of the area.

This description, combined with Chapter Three, which involves land use and zoning analysis, will assist in the formation of goals and objectives for the commercial district itself. After these areas have been described, general findings will be given concerning the current status of the study area.

\section{Location of the Study Area}

Broad Street extends south from the central business district of the City of Providence, Rhode Island. Entering from the south, the commercial district begins at Detroit Avenue and the overpass for Route 95. It continues north to the intersection of Elmwood Avenue and Grace Church Cemetery. This street forms the western border of the Upper and Lower South Providence neighborhoods. The neighborhood known as Elmwood is located on the eastern border. It provides a direct route from Downtown Providence to Cranston and also is a way of accessing the east entrance to Roger Williams Park. Figure 1 shows a neighborhood map of the City of Providence with the Broad Street area highlighted.

The length of the Broad Street Commercial District covered by ENHS is 1.5 miles. It contains a mixture of commercial, residential and mixed use buildings, 


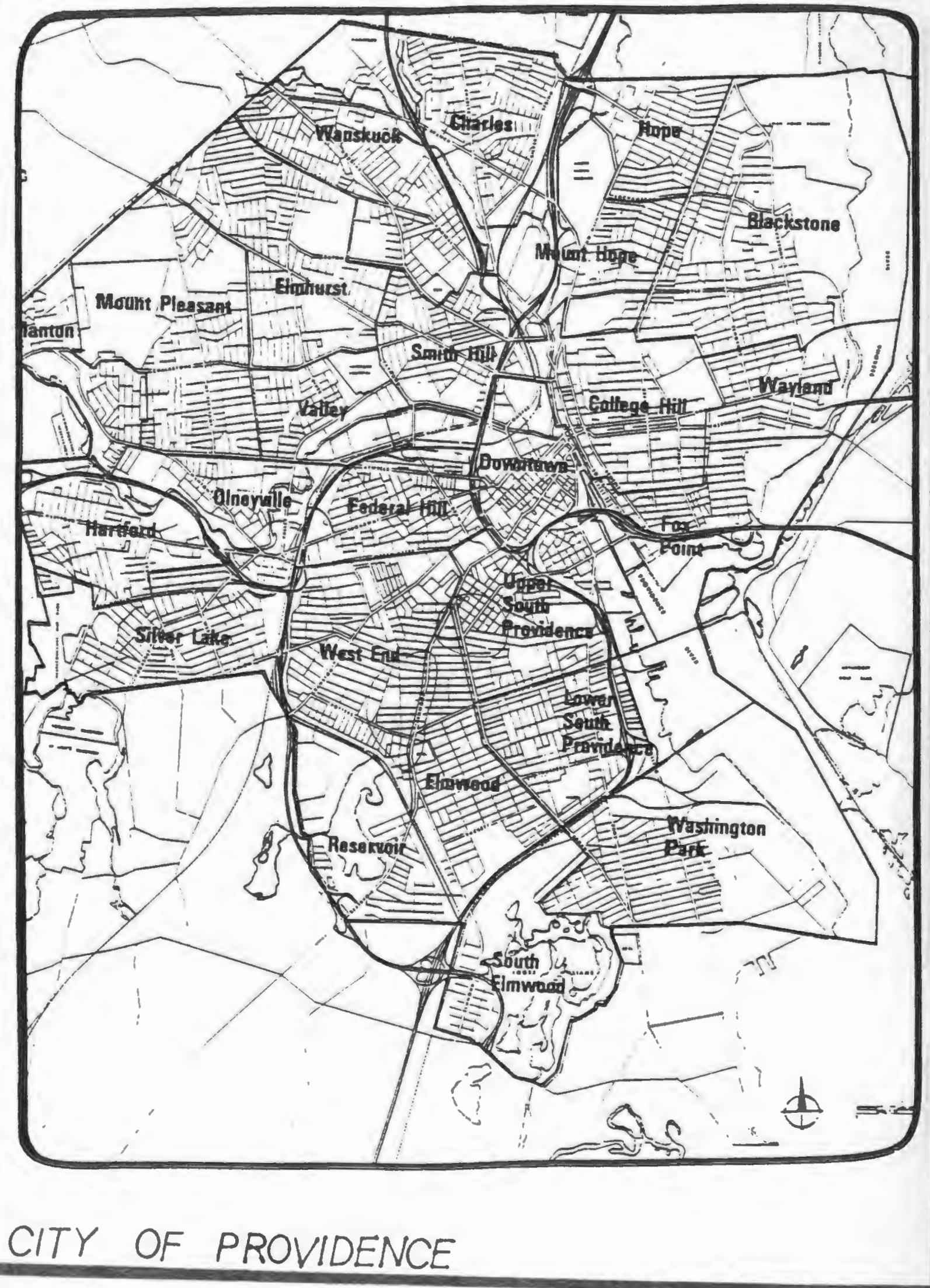


making the street an exceptionally challenging area for revitalization.

According to an inventory of commercial businesses performed by ENHS in January 1991, it contained at least 94 establishments. Table 1 contains a listing of business types which were counted in that inventory. A further breakdown of these businesses is covered in Chapter Three.

Table 1

Inventory of Broad Street Businesses

Type Total

Type

Total

Auto Sales

Auto Supply

Auto Repair

Bakery

Beauty Supply

Cleaners

Clothing

Financial

Fitness Center

Funeral Homes

Furniture

Hardware

4
7
7
1
2
5
7
1
1
4
2
1

Hair Salon

1

Health Care

6

Jewelry

Liquor

Markets

2

1

2

5

7

1

1

4

1

Paint Supply

Pharmacies

Real Estate

Religious

Restaurants

Tailor

Video Rental

\section{3}

17

1

2

3

1

14

1

1

Source: ENHS Jan. 1991

\section{Historical}

According to a history of the City of Providence written by the Rhode Island 
Historical Preservation Commission (1978), Broad Street was formed from an old Indian path and originally named Pawtuxet Road. Its pattern of development is typical of much of the early settlement of Providence. Figure 2 shows a map of Providence as it existed in the 1700's with its connection to the center of the City.

Like much of the City's original road system, Broad Street was developed from the center outward and made up one of the arms in a star shaped pattern of growth. Until the mid 1800's, it served as an access road to Cranston and was bordered on either side by early residences and farm land. This gradual development can be partially seen in Figure 3 which includes maps of the upper section of Broad Street during the 1800 's.

During the Industrialization Period of the 1850's businesses and homes began to develop along Broad Street. Some of the businesses which evolved in the surrounding area included a packing box factory, a rubber tubing plant, a paper collar factory and a textile manufacturer. In the same period, the neighborhoods bordering Broad Street began to form, and later became known as Elmwood and Upper and Lower South Providence.

At first, only those wealthy enough to build large homes lived there. Later, as factories developed, the area became home to immigrants from Ireland, England and Russia who provided the labor supply. During this period the neighborhoods began to fill in, and a variety of housing types were built. These ranged from large, single family residences to triple deckers which became home to several families.

In the 1920's and 1930's the neighborhoods bordering Broad Street continued 


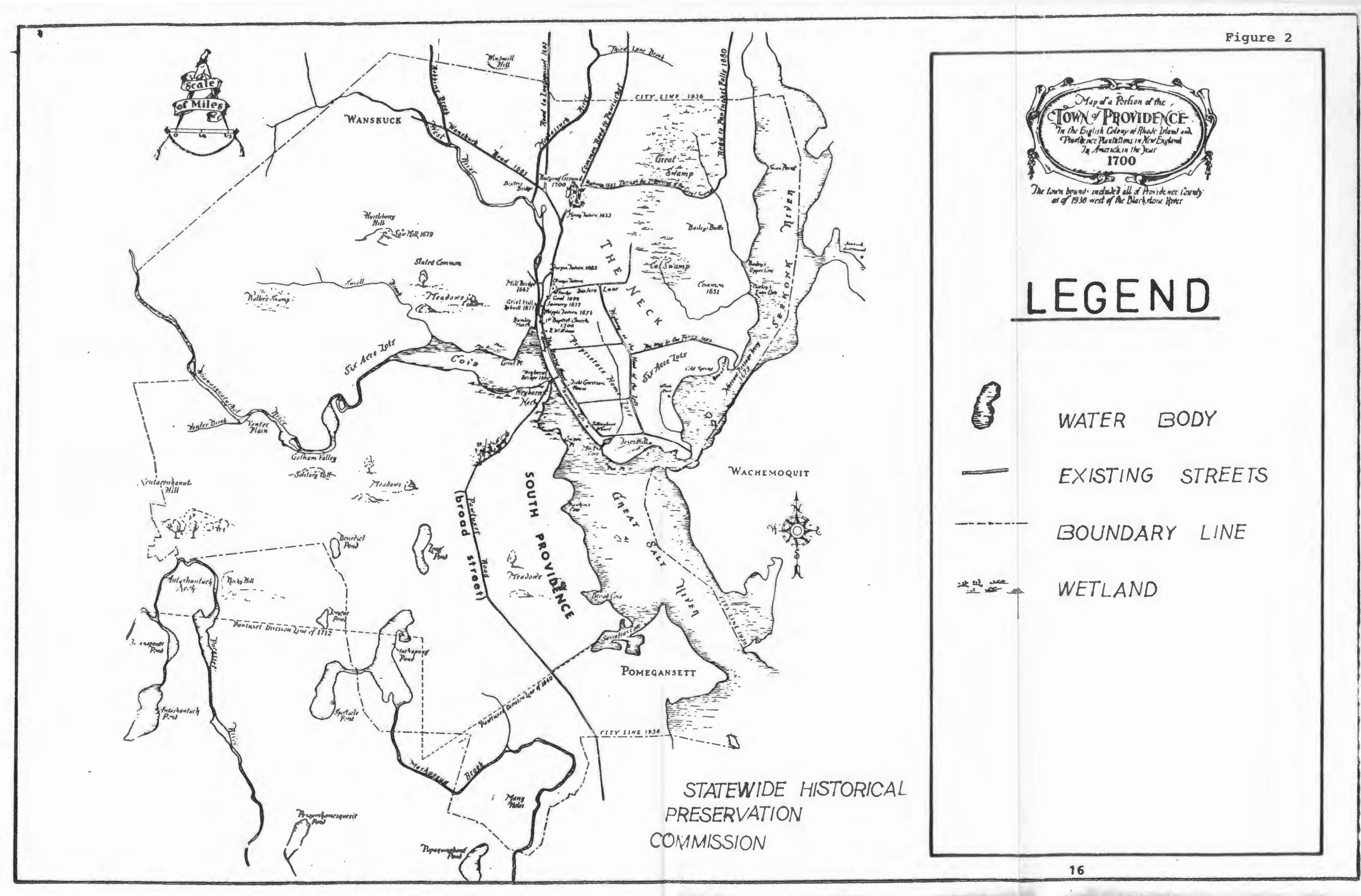



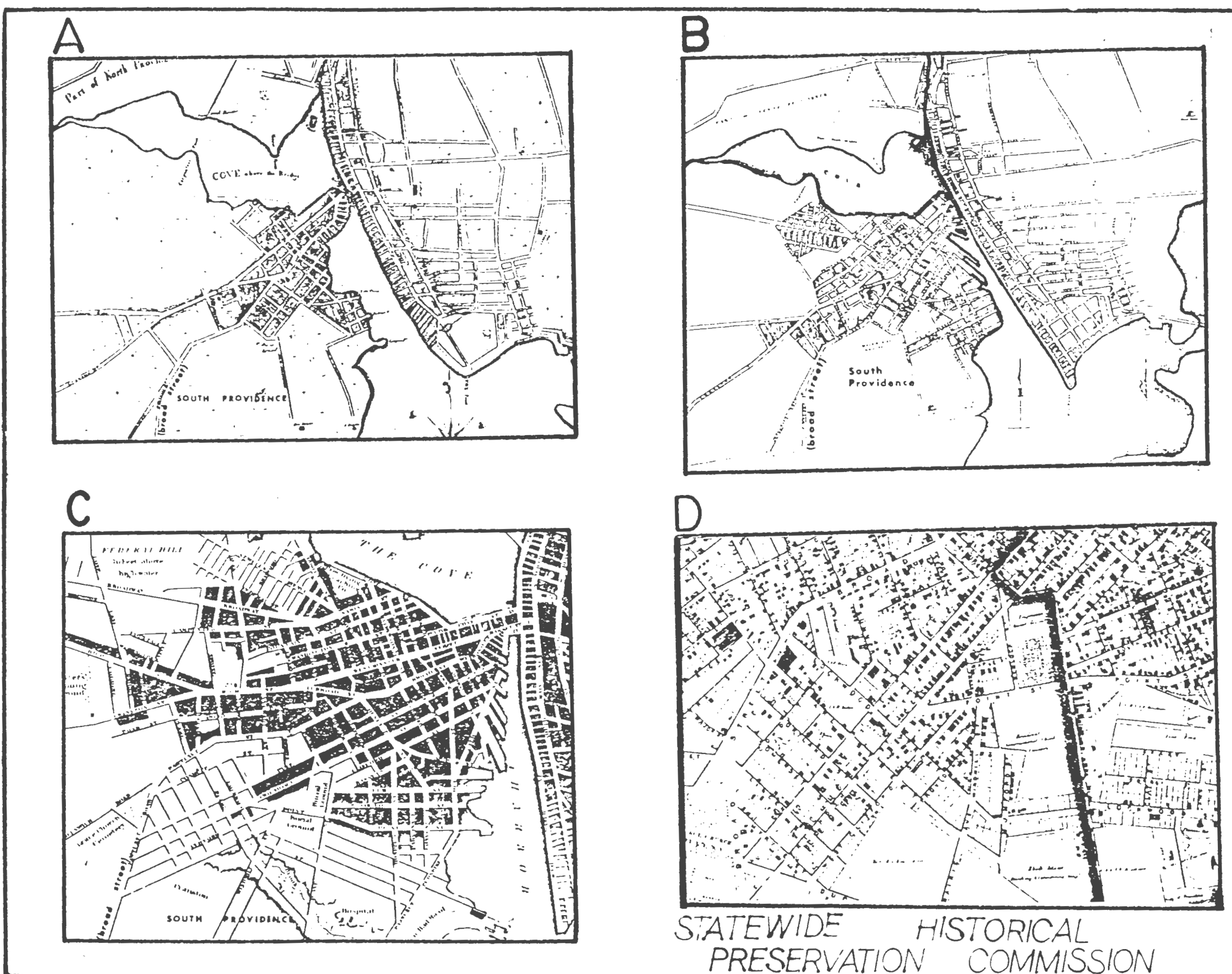

HISTORICAL MAPS

OF PROVIDENCE

$1803-7857$

A DANIEL ANTHONY MAP OF

PROVIDENCE, 7803

B DANIEL ANTHONY MAPS OF

PROVIDENCE, 1823

C MOORE PLAN OF THE CITY OF

PROVIDENCE, 1844

D H.F. WALLING MAP OP

PROVIDENCE, 1857

PRESERVATION COMMISSION 
to grow and became densely populated. As a result of this expansion, along with more flexible modes of transportation, such as trolleys and cars, the appearance of the area began to change. In order to provide more space for these types of transportation, it became necessary to widen streets and pave over small lots for parking, resulting in an increasingly barren look for this major boulevard.

As the area continued to become more densely populated, those residents who could afford to do so were able to move outward to the suburbs. This "flight" from the crowded inner city resulted in a changing demographic profile which continued into the 1980's and will be addressed in the following section. As the area around Broad Street grew, so did its commercial businesses. Easily accessed by foot,

residents were able to frequent them regularly. Establishments that developed included clothing stores, produce markets, and health related services such as doctors, dentists and pharmacies. Also added were a theater and several churches and synagogues. Some of the original structures are still standing today.

As the economic base of the City and residents in the bordering neighborhoods began to deteriorate, so did the structure of the commercial district of Broad Street. The businesses, which provided services to the immediate area, changed along with the needs of their customers and were eventually replaced by those currently in existence.

\section{Demographic analysis}

In order to develop an accurate representation of the clientele for Broad 
Street businesses it was necessary to analyze available census data. Due to the slow release of the 1990 U.S. census counts, material used for this report was obtained from CACI, a data service which specializes in forecasting census data. Information for this section was derived from forecasts done by CACI for the City of Providence and each of its 37 census tracts.

Figure 4 shows a map of Providence as it is divided into census tracts. Tracts $2,3,4,5$, and 6 were determined to be those which were located within the Broad Street area's neighborhoods of Elmwood and South Providence. Information for these tracts was compared to that of the rest of the City both in aggregated and disaggregated forms. Tables 2,3 , and 4 contain the census data for the entire City and each of the five census tracts which were determined to be located around the study area. Table 2 lists census figures according to the 1980 U.S. Census. Table 3 and 4 contain projected figures for 1989 and 1994.

According to CACI data, the five census tracts located within the Broad Street area have some distinct characteristics that are different from the rest of the City. This analysis will examine those differences in the census data and the changes which occurred from 1980 to 1989 within the five census tract as they related to the City of Providence. Also included in the discussion will be the projected figures for 1994.

It should be noted that, for purposes of this study, these five specific census tracts will be divided and discussed as those that most closely match the borders of the three neighborhoods. While these five tracts cover areas which are larger than the existing neighborhoods, residents in these tracts will most likely be the 

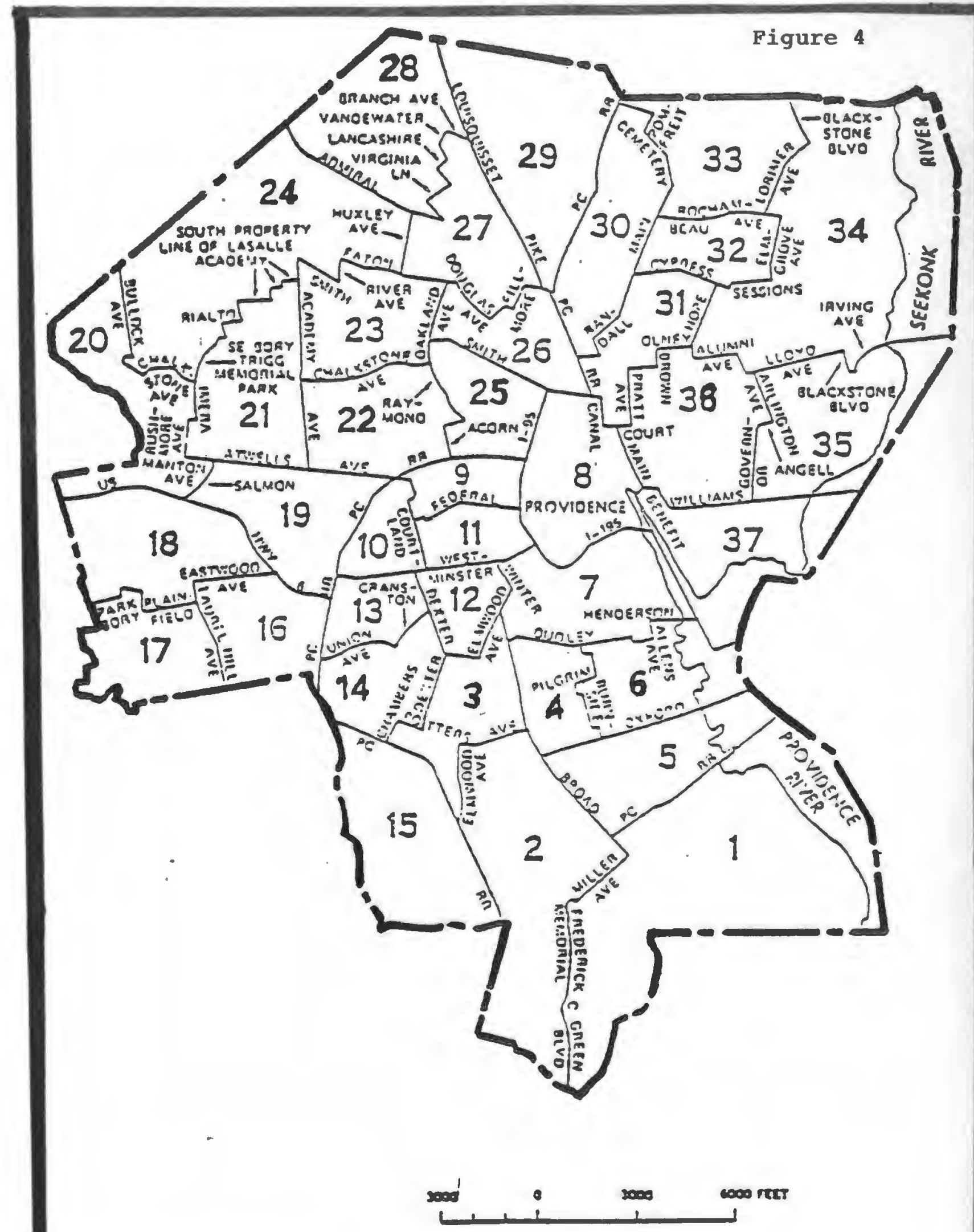

\section{CITY OF PROVIDENCE}


Table 2

1980

\begin{tabular}{|c|c|c|c|c|c|c|c|c|c|}
\hline & CITY & 2 & 3 & 4 & 5 & 6 & AVG. 2-6 & TOTAL & 2 \\
\hline POPULATION & 156804 & 8611 & 5608 & 3334 & 2882 & 1374 & & 21809 & 0.14 \\
\hline HOUSEHOLDS & 60157 & 2950 & 2193 & 1031 & 942 & 445 & & 7561 & 0.13 \\
\hline FAMILIES & 36726 & 1930 & 1114 & 710 & 661 & 308 & & 4723 & 0.13 \\
\hline HOUSEHDLD SIZE & 2 & 3 & 2 & 3 & 3 & 3 & 2.91 & & \\
\hline FAMILY SIIE & 3 & 4 & 4 & 4 & 4 & 4 & 3.82 & & \\
\hline INCOME (MILS) & 914 & 39 & 25 & 11 & 11 & 6 & & 90 & 0.10 \\
\hline PER CAPITA IKCOME & $58: !$ & 4532 & $435:$ & 3185 & 3654 & 3987 & & & \\
\hline AVERAGE FAM. INC. & 18485 & 14234 & 14283 & 10695 & 12562 & 14850 & 13324.80 & & 0.72 \\
\hline MEDIAN FAK. INC. & 14951 & 11476 & 11309 & 8385 & 9213 & 11402 & 10477 & & 0.70 \\
\hline AVEF,AGE HH. INC. & 15198 & 13245 & 11202 & 10298 & $\$ 1178$ & 17309 & 11646.40 & & 0.77 \\
\hline MEDIAK HH. INC. & 11452 & 9896 & 8563 & 7115 & 8143 & 8750 & 8493.40 & & 0.74 \\
\hline \multicolumn{10}{|l|}{ HOUSEHOLD INCOHE } \\
\hline $0-9,999$ & 26365 & 1488 & 1273 & 620 & 572 & 242 & & 4195 & 0.16 \\
\hline $310,000-14,999$ & 10287 & 472 & 382 & 159 & 145 & 75 & & 1.33 & 0.12 \\
\hline $515,000-24,999$ & $1310^{i}$ & 573 & 380 & 173 & 140 & 67 & & 1333 & 0.1 \\
\hline $625,000-34,998$ & 2036 & 308 & 105 & 49 & 68 & 47 & & 577 & 0.1 \\
\hline $435,000=43,999$ & $252 \%$ & 61 & 31 & 25 & 11 & 8 & & 136 & 0.05 \\
\hline $550,000-74,993$ & 1058 & 41 & 12 & 5 & 0 & 6 & & 64 & 0.06 \\
\hline$\$ 75,000$ - UP & 742 & 7 & 10 & $\hat{0}$ & 6 & 0 & & 23 & 0.03 \\
\hline \multicolumn{10}{|l|}{ AGE Z:3TRIBUTION } \\
\hline $0-4$ & 9887 & 848 & 509 & 346 & 337 & 121 & & 2169 & 0.22 \\
\hline $5-11$ & 13464 & 1133 & 566 & 518 & 438 & 205 & & $286 \varepsilon$ & 0.21 \\
\hline $1 \hat{\imath}-1 E$ & $\operatorname{doc} 30$ & $\varepsilon:$ & 423 & 337 & 374 & 146 & & 2107 & 0.20 \\
\hline $17-21$ & 20820 & 799 & 675 & 318 & 292 & 134 & & $2 x: 8$ & $\therefore ! !$ \\
\hline $22-29$ & 23796 & 1268 & 909 & 455 & 367 & 166 & & 3165 & 0.13 \\
\hline $30-44$ & 23680 & 1472 & 934 & 579 & $44 !$ & 243 & & 3669 & 0.15 \\
\hline $45-54$ & 13890 & 607 & 478 & $32 n$ & 211 & 136 & & 1752 & 0.13 \\
\hline $55-64$ & 16557 & 638 & 443 & 220 & 186 & 122 & & 1603 & 0.10 \\
\hline $65+$ & 24057 & 1019 & 665 & $24 !$ & 236 & 101 & & 2262 & 0.09 \\
\hline
\end{tabular}

$\begin{array}{lllllll}\text { AVERAGE AGE } & 36 & 32 & 33 & 29 & 28 & 30\end{array}$

30.32

MES:AN AGE

$\begin{array}{llllll}30 & 26 & 27 & 24 & 22 & 26\end{array}$

25.14

RACE C:STR!BUT!OH:

UHITE

BLACK

OTHER

$\begin{array}{rrrrrr}127320 & 4363 & 2805 & 985 & 704 & 371 \\ 18546 & 2325 & 1652 & 1403 & 1559 & 827 \\ 10938 & 1923 & 1151 & 946 & 619 & 176\end{array}$

9228

7766

4815
0.07

0.42

0.44

SOURCE: CACI 
Table 3

1989

CITY $23 \quad 4 \quad 5 \quad 6 \quad$ AVE. 2-6 TOTAL 2

\begin{tabular}{|c|c|c|c|c|c|c|c|c|c|}
\hline POPULATION & 162870 & 8344 & 5825 & 3463 & 2933 & 1427 & & 22652 & 0.14 \\
\hline HOUSEHOLDS & 68249 & 3340 & $248 E$ & 1167 & 1065 & 503 & & 8561 & 0.13 \\
\hline FAMILIES & 39213 & 2079 & 1183 & $70 ?$ & 715 & 333 & & 5077 & 0.13 \\
\hline HOUSEHOLD SIZE & 2 & 3 & 2 & 3 & 3 & 3 & 2.67 & & \\
\hline FAMULY SIZE & 3 & 3 & 3 & 4 & 4 & 4 & 3.58 & & \\
\hline INCOME (MILS) & 1688 & 74 & 46 & 21 & 20 & 10 & & 171 & 0.10 \\
\hline PER CAPITA & 10361 & 8265 & 7888 & 5913 & 6614 & 7186 & & & \\
\hline AVERAGE FAK. INC. & 29929 & 23880 & 23635 & 18064 & 20892 & 24880 & 22270.20 & & 0.74 \\
\hline MEDIAN FAK. INC. & 25392 & 19818 & 20217 & 14299 & 15677 & 20247 & 18051.60 & & 0.71 \\
\hline AVERAGE HH, INC. & 24725 & 22133 & 18484 & 17545 & 18587 & 20388 & 13927.40 & & 0.79 \\
\hline MEDIAN HH. INS. & 19623 & 16948 & 14302 & 12212 & 13964 & 14688 & 14422.80 & & 0.73 \\
\hline \multicolumn{10}{|l|}{ HOUSEHOLD IMCOME } \\
\hline $0-9999$ & 18740 & 1100 & 873 & 522 & 384 & 184 & & 3063 & 0.16 \\
\hline $110,000-14,999$ & 8950 & 443 & 430 & 139 & 201 & 72 & & 1285 & 0.14 \\
\hline$\$ 15,000-24,999$ & 13917 & 652 & 551 & 211 & 218 & 98 & & $173 \hat{0}$ & 0.12 \\
\hline$\$ 25,000-34,993$ & 10244 & 433 & 317 & 142 & 111 & 56 & & 1059 & 0.10 \\
\hline$\$ 35,000-49,999$ & 8940 & 439 & 238 & 101 & 97 & 57 & & 932 & 0.10 \\
\hline $150,000-74,999$ & 4588 & 208 & 34 & $4 E$ & 44 & 29 & & 361 & 0.08 \\
\hline $675,000-U P$ & 2863 & 65 & 43 & 6 & 10 & 7 & & $13 !$ & 0.05 \\
\hline \multicolumn{10}{|l|}{ AGE DISTRIBUTION } \\
\hline $0-4$ & $1088:$ & 933 & 550 & 381 & 423 & 140 & & 2427 & 0.22 \\
\hline $5-11$ & 14231 & 1137 & 696 & 456 & 457 & 166 & & 2912 & 0.20 \\
\hline $12-16$ & 9596 & 767 & 431 & 329 & 282 & 127 & & $\$ 936$ & 0.20 \\
\hline $17-21$ & 17018 & 786 & 516 & 321 & 262 & 138 & & 2023 & 0.12 \\
\hline $22-29$ & 20330 & 1208 & 722 & $47 \hat{z}$ & $45:$ & 198 & & 3052 & 0.15 \\
\hline $30-44$ & 37430 & 1930 & 1334 & 686 & 518 & 284 & & 4752 & 0.13 \\
\hline $45-54$ & 12922 & 725 & 490 & 304 & 211 & 122 & & 1852 & 0.14 \\
\hline $55-64$ & 13735 & $5: 3$ & $4: 0$ & $\therefore 4$ & 167 & 114 & & 1454 & 0.11 \\
\hline $65+$ & 26728 & 939 & 676 & 270 & 221 & 138 & & 2244 & 0.08 \\
\hline
\end{tabular}

$\begin{array}{llllllll}\text { AVERAGE AGE } & 37 & 32 & 33 & 30 & 28 & 32 & 30.96\end{array}$

$\begin{array}{llllllll}\text { MEDIAN AGE } & 34 & 28 & 30 & 26 & 23 & 28 & 26.96\end{array}$

RACE DISTRIBUTION

UHITE

$\begin{array}{llllll}130537 & 4300 & 2762 & 950 & 672 & 355\end{array}$

$9039 \quad 0.07$

BLACK

$\begin{array}{llllll}20458 & 2570 & 1824 & 1517 & 1674 & 888\end{array}$

8473

$0.4 i$

OTHER

$\begin{array}{llllll}1: 875 & 3074 & 1293 & 936 & 647 & 184\end{array}$

$514: 0.43$

SOURCE: CACI 
Table 4

1994

\begin{tabular}{|c|c|c|c|c|c|c|c|c|c|}
\hline & CITY & 2 & 3 & 4 & 5 & 6 & AVG. 2-6 & TOTAL & 2 \\
\hline POPULATION & 163374 & 8972 & 5843 & 3473 & 3002 & 1431 & & 22721 & 0.14 \\
\hline HOUSETHËDS & 71776 & 3513 & 2614 & 1227 & 1120 & 529 & & 9003 & 0.13 \\
\hline FAMILIES & 39874 & 2123 & 1196 & 784 & 733 & 341 & & 5177 & 0.13 \\
\hline HOUSEHOLD SIZE & 2.14 & 2.49 & 2.12 & 2.76 & 2.68 & 2.68 & 2.546 & & \\
\hline FAMILY SILE & 2.93 & 3.36 & 3.29 & 3.62 & 3.52 & 3.52 & 3.462 & & \\
\hline INCOHE (MILS) & 1851.3 & 81.3 & 50.6 & 22.5 & 21.9 & 11.2 & & 188 & $0.3 i$ \\
\hline PER CAPITA INCOME & 11332 & 9064 & 8667 & 6476 & 7298 & 7844 & 7869.8 & & 0.69 \\
\hline AVERAGE FAM. INC. & 31178 & 25041 & 24783 & 18954 & 21985 & 26158 & 23384.2 & & 0.75 \\
\hline MEOIAN FAK. INC. & 26609 & 20552 & 21143 & 14674 & 16512 & 21084 & 18793 & & 0.71 \\
\hline AUERRAGE HH. IKi. & 25793 & 23148 & 19374 & 18329 & 19563 & 21219 & 20326.6 & & 0.75 \\
\hline MEDIAN HH. INC. & 20402 & 17638 & 14783 & 12832 & $1417 !$ & 14910 & 14866.8 & & $0.7 i$ \\
\hline \multicolumn{10}{|l|}{ HDUSEHOLD INCOME } \\
\hline $0-9999$ & 18566 & 1097 & 866 & 524 & 379 & 183 & & 3049 & 0.16 \\
\hline $510,000-24,939$ & 9876 & 483 & $46 !$ & 158 & 217 & 83 & & 1402 & 0.14 \\
\hline$\$ 15,000-24,999$ & 14155 & $66 \%$ & $5 i 0$ & 213 & 231 & 98 & & 1781 & 0.13 \\
\hline$\$ 25,000-34,999$ & 10681 & 451 & 344 & 159 & 113 & 62 & & 1129 & 0.11 \\
\hline$\$ 35,000-49,999$ & 9793 & 475 & 267 & 107 & $11 !$ & 58 & & 1018 & 0.10 \\
\hline $550,000-74,999$ & 5405 & 248 & 57 & 55 & 54 & 35 & & 449 & 0.08 \\
\hline$\$ 75,000-U F$ & 3500 & 90 & 49 & 11 & 15 & 10 & & 175 & 0.05 \\
\hline \multicolumn{10}{|l|}{ AGE DISTRIBUTION } \\
\hline $0-4$ & 9347 & 869 & $45 E$ & 363 & 386 & 135 & & 2209 & 0.24 \\
\hline $5-11$ & 14767 & 1186 & 723 & 474 & 505 & 176 & & 3064 & 0.21 \\
\hline $12-16$ & 9815 & 755 & 472 & 304 & 295 & 115 & & 1941 & 0.20 \\
\hline $17-21$ & 16416 & 747 & 545 & 298 & 229 & 118 & & 1937 & 0.12 \\
\hline $22-29$ & 17813 & 1177 & 617 & 468 & 409 & 192 & & 2863 & 0.16 \\
\hline $30-44$ & 39971 & 1956 & 1381 & 713 & 580 & 300 & & 4930 & 0.12 \\
\hline $45-54$ & 16020 & 870 & $56 !$ & 312 & 227 & 144 & & 2114 & 0.13 \\
\hline $55-64$ & 11958 & 545 & 407 & 275 & 149 & 98 & & 1474 & 0.12 \\
\hline $65+$ & 27267 & 867 & 681 & 266 & 222 & 153 & & 2189 & 0.08 \\
\hline
\end{tabular}

AVERAGE AGE

$\begin{array}{llllll}38 & 31.8 & 33.8 & 30.7 & 27.9 & 32.8\end{array}$

31.42

$\begin{array}{lllllll}35.1 & 28.3 & 31.2 & 27.1 & 23.7 & 29.1 & \end{array}$

RACE DISTRIBUTION

WHITE

BLACK

$\begin{array}{llllll}129183 & 4083 & 2624 & 88 * & 618 & 327\end{array}$

8536

0.07

DTHER

$\begin{array}{llllll}21767 & 2736 & 1937 & 1579 & 1732 & 919\end{array}$

8903

0.41

$\begin{array}{llllll}12424 & 2153 & 1282 & 1010 & 652 & 185\end{array}$

5282

0.43

SOURCE: CACI 
beneficiaries of a commercial revitalization project.

Another area of concern in the census data presented here is that it does not clearly define the term Other as it pertains to Race. The persons who are counted as Other are comprised of all those individuals not classified as White or Black. This means that the large numbers of Asians and Hispanics who live there are not counted.

\section{The Five Census Tracts Compared to Providence}

Perhaps the most significant difference between the study area and the City is the concentration in these census tracts of a large portion of the non-white population of City. According to CACI data for $1980,7 \%$ of the total white population resided within these tracts while $42 \%$ of the City's Blacks and $44 \%$ of those groups classified as Other lived there. Also of note is the fact that the figures for the percentage of the white population remain constant into 1994 while those for Blacks and Other decreased slightly to $41 \%$ and $43 \%$ respectively.

By looking at the total population figures for this specific area, the data shows a forecasted change in its minority population. In 1980 the area was comprised of $81 \%$ whites, $11.8 \%$ Blacks, and $6.9 \%$ Other. Figures for 1989 and 1994 show the white population decreasing to $80 \%$ of the total while the Black population is projected to increase to $13 \%$ of the area's population and those groups classified as Other to increase to $7.6 \%$.

Comparing the total population of the area to the City, it contained $12 \%$ of 
the City's population in 1980 and increased to $14 \%$ in 1989. Projected figures for 1994 show that this percentage of the population will remain constant. While these figures stay at the same level others for this area do change.

For instance, of the total area population the household size for 1980 was 2.91 which was higher than the City's figure of 2 . This total shown to decrease to 2.67 by 1989 and 2.54 by 1994 . The household size for the City however, is shown to be increasing slowly to 2.14 during the same time period.

Family size for the area is also recorded as being higher (3.82) than the City (3) and predicted to decrease to 3.46 by 1994 while the family size for the City remains fairly constant (2.93).

The population of this area is also younger on average than the rest of the City. In 1980 the average age within the five census tracts evaluated was 30 compared to an average age of 36 for the City. Both these figures are projected to increase by 1994 with the average age of the area being 31 compared to the City's average of 38 .

Income levels for these tracts is shown to be consistently lower than the rest of the City. The average family income in 1980 was $72 \%(\$ 13,324.8)$ of Providence's average income of $\$ 18,845$. Average household income for 1980 was $77 \%(\$ 11,646.4)$ of the City's average which was $\$ 15,198$.

Also related to income are figures showing that in $198016 \%$ of households which earned less than $\$ 10,000$ per year lived in the Broad Street area while only $3 \%$ of households earning more than $\$ 75,000$ resided there. By $1994,16 \%$ of households earning $\$ 10,000$ will still reside in the area while the number of households earning 
more than $\$ 75,000$ will increase to $5 \%$ of the City's total households earning the same amount.

\section{Neighborhood Analysis}

As mentioned in the introduction of this report, there are three neighborhoods which border the Broad Street Commercial District. Figure 5 shows a neighborhood map of the City of Providence with the study area highlighted. Elmwood is located within census tracts 2 and 3, while Upper South Providence contains census tracts 4 and 6 and Lower South Providence covers census tract 5. The data for these areas was evaluated and the following is a description of the key issues highlighted.

\section{Elmwood}

The Elmwood section of Providence is located to the west of Broad Street and contained within census tracts 2 and 3 . It should be noted that the neighborhoods of the West End and Reservoir are also included in these tracts and were not able to be deleted from the data given.

Figures for 1980 show that the total population for these tracts was 14769 and composed of $49 \%$ (7168) Whites, $27 \%$ (3977) Blacks, and $24 \%$ (3434) Other. The racial distribution for this area is projected to continue changing into 1994 with the area being composed of $45 \%$ (6707) Whites, $31 \%$ (4673) Blacks, and 23\% (3435) Other.

The 1980 data for these census tracts showed average family income to be 


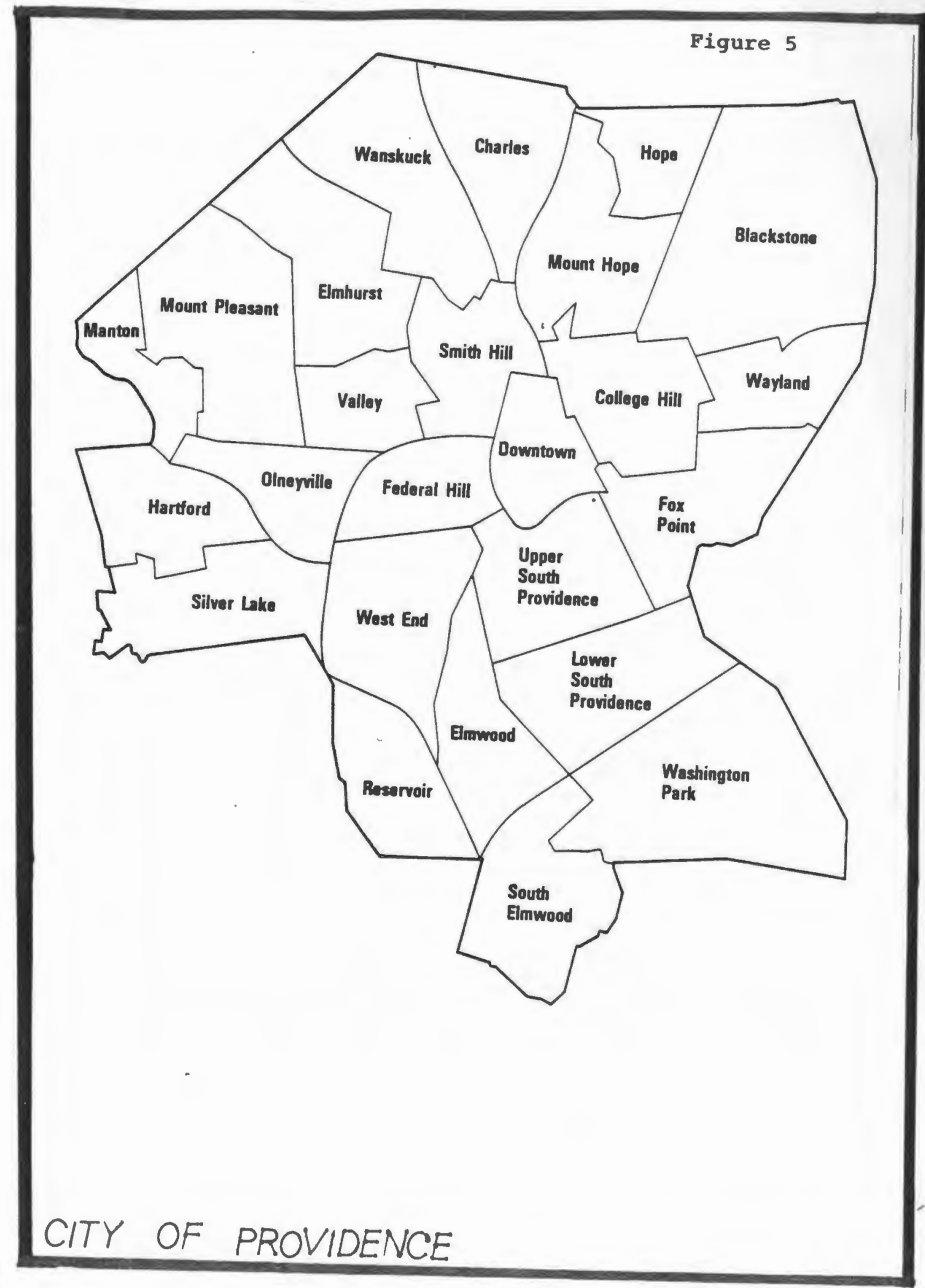


$\$ 14,258$, which was higher than the average family income for the entire area $(\$ 13,324)$. Average household income was $\$ 13,245$ compared to the rest of the census tracts ( $\$ 11646)$. These figures are projected to continue to increase by 1994 with the average family income for these two census tracts becoming $\$ 24,912$ while the rest of the area's average will be $\$ 23,384$.

Also related to income, the 1980 census figures show that $66 \%$ (2761) of those households who earned less than $\$ 10,000$ in the area lived within census tracts 2 and 3. This percentage is predicted to decrease to $64 \%$ (1963) by 1994 .

The most dramatic increase in total numbers however is the increase in the total number of households earning $\$ 75,000$ or more. 1980 figures show 17 households earning this amount. By 1989 this figure was projected to have increased to 108 households and by 1994 to 139 households. This drastic increase could be the reflection of a concerted effort on the part of area residents to revitalize their neighborhoods.

\section{Upper South Providence}

Census tracts 4 and 6 contain a major portion of the neighborhood of Upper South Providence. Figures given for racial distribution show that in 1980 this area was comprised of $29 \%$ (1356) Whites, $47 \%$ (2230) Blacks, and 23\% (1122) Other. By 1994 the percentage of Whites living there is projected to decrease to 25\% (1211) Whites while the percentage of Blacks increases to 50\% (2498) and Other increases to $24 \%$ (1195). The average family income for this neighborhood in 1980 was 
$\$ 12,772.5$ compared to $\$ 13,324.8$ for the entire area. In 1980 the average household income was also lower $(\$ 11,303.5)$ than that of the average household income for the area which was $\$ 11646.4$. By 1994 both the average family income $(\$ 22,556)$ and the average household income (\$13871) are projected to have increase but will still not be as high as the average family income $(\$ 23,3842)$ and the average household income $(\$ 14,866.8)$.

Of those households earning less than $\$ 10,000,20 \%$ lived in Upper South Providence while there were no households who earned $\$ 75,000$ or more. By 1994 , $23 \%$ of the households (707) earning less than $\$ 10,000$ are projected to live in the area, and the number of households earning $\$ 75,000$ or more is forecasted to increase to $12 \%$ (21) of the households in the Broad Street Commercial District.

\section{Lower South Providence}

Almost the entire neighborhood of Lower South Providence is located within census tract 5. It also has the distinction of consistently having the lowest income figures for the study area. This same neighborhood is also the location of most of the social service agencies which serve the area, such as homeless shelters, soup kitchen and other non-profit organizations.

In 1980 the income figures for this tract show that the average family income was $\$ 12,662$ compared to the area's average of $\$ 13,324$. By 1989 the average family income was estimated to be $70 \%(\$ 20,892)$ of that for the entire City. By 1994 the average family income is expected to increase to $\$ 21985$ while the area's average 
family income will remain at $\$ 23,354$.

In 1980 the racial mix of this neighborhood was reported to be $24 \%$ (704) White, 54\% (1559) Black, and 21\% Other. By 1989, of the 2,993 residents within this census tract, CACI estimated the racial distribution of the area to be $22 \%(672)$ White, 55\% (1674) Black, and 21\% (647) Other. Compared to the other neighborhoods, Lower South Providence population contained 7\% of the whites, $20 \%$ of the Blacks, and $13 \%$ of those identified as Other in 1989. According to figures projected for 1994, the total percentage of Whites in the area will decrease to $20 \%$ (618) while the percentage of Blacks will increase to $57 \%$ (1732) and the percentage of Other will remain constant at $21 \%(652)$.

\section{Summary of Findings}

When developing revitalization guidelines for a commercial district, it is important that the needs of the residents in the surrounding area be taken into consideration. Unless the requirements of this population is met, it is unlikely that success will occur.

Such information as income and ethnic composition are important in order to develop a plan which will cater to the needs of those individuals and families who are most likely to shop there. Knowledge of this information is also critical in the selection of a revitalization committee. According to Rohe and Gates (1985:75) awareness, or the lack of awareness, of different neighborhood groups and their needs can determine the acceptance of any planning efforts. 
Given the current status of businesses in the area and the income levels and purchasing capacity of residents which live around Broad Street, a program which involves a moderate to high level of involvement on the part of the businesses and citizens would appear most appropriate. By encouraging these two groups to get involved in the revitalization process a heightened sense of neighborhood pride should result.

The next chapter will focus on the physical aspects of the Broad Street Commercial District. Included will be a description of land use and existing conditions. Along with this chapter it will provide a basis for the development of commercial revitalization guidelines which will address the specific needs of the entire Broad Street area. 


\section{CHAPTER THREE}

INVENTORY OF EXISTING CONDITIONS 


\section{Introduction}

For the purpose of this study, it was decided that the Broad Street area should be divided into four sections. The chapter is divided into two parts. First, it will discuss why the study area is divided into sections. Next, a description of each section will be given including each building's location, facade condition and availability of parking. Also included in each section will be its zoning and circulation patterns. After each of the sections has been described, general conclusions pertaining to the entire commercial district will be presented along with implications for planning.

\section{Approach}

Initially, the suggestion for developing a sectional approach to revitalizing Broad Street was presented to ENHS by Neighborhood Reinvestment Corporation (NRC). The national NHS network is part of NRC and assists local NHS organizations which are trying to encourage commercial and economic development within their neighborhoods. NRC suggested that Broad Street be divided into at least four sections because of its length (1.5 miles). Each of the sections contains an easily identifiable type of activity and appearance to be described in this section.

The main reasons for using this approach are:

- To enable the revitalization to take place in several sections at the same time. This should result in an acceleration of the process rather than the strategy of working from one end of the area to the other.

- To encourage priority setting. This should make the project more 
manageable. By establishing priorities for each section, strategies for those businesses which are in need of more assistance than others can be addressed.

- To establish tasks for each section and throughout the entire length of the study area. By dividing the work for each section into a series of tasks, both business owners and concerned citizens can be encouraged to participate in the revitalization process.

- To make achievement of the overall goal of commercial revitalization more attainable. By having revitalization activity going on in each of the sections, this process should take less time than if it were approached in the traditional manner.

\section{The Inventory Process}

In order to identify issues and concerns for the development of revitalization guidelines for the Broad Street Commercial District, it was necessary to take an inventory of existing conditions. By doing so, the strengths and weaknesses of the area can be identified, thereby increasing the likelihood of a revitalization plan which will reflect the true needs of the businesses along Broad Street.

The inventory for this document was performed in two steps. The first step was to walk the entire study area and record the location of each business, residential unit and vacant lot. The second step was to examine a series of photographs of the study area taken during the walk.

An inventory of each of the four sections was then developed and is included 
in the remainder of this chapter. Each section will include a discussion of land use, parking, circulation, the number of residential units and general facade conditions of all structures within the section. Each of the four sections has a table which lists all of the structures located in it, its facade condition and available parking. Criteria for determining facade condition are contained in Appendix A. Basically, they are represented in the following manner:
A - Excellent
B - Satisfactory
C - In need of minor repairs
D - In need of major repairs

Available parking is signified by A) On street parking only,

B) Accessible off street parking.

\section{Zoning}

Figure 7 contains a section of the 1990 Providence Zoning map. This map shows that the entire length of Broad Street is zoned C-1 and C-2, which are defined by the City of Providence as follows:

\section{C-1 Limited Commercial Zone}

A C-1 limited commercial zone is one which includes small neighborhood retail establishments, normally patronized by residents of the immediately adjacent residential districts.

\section{C-2 General Commercial Zone}

A C-2 zone contains those enterprises serving a considerable segment of the city's population in the distribution of goods and services, but usually not attracting customers form the whole City. 


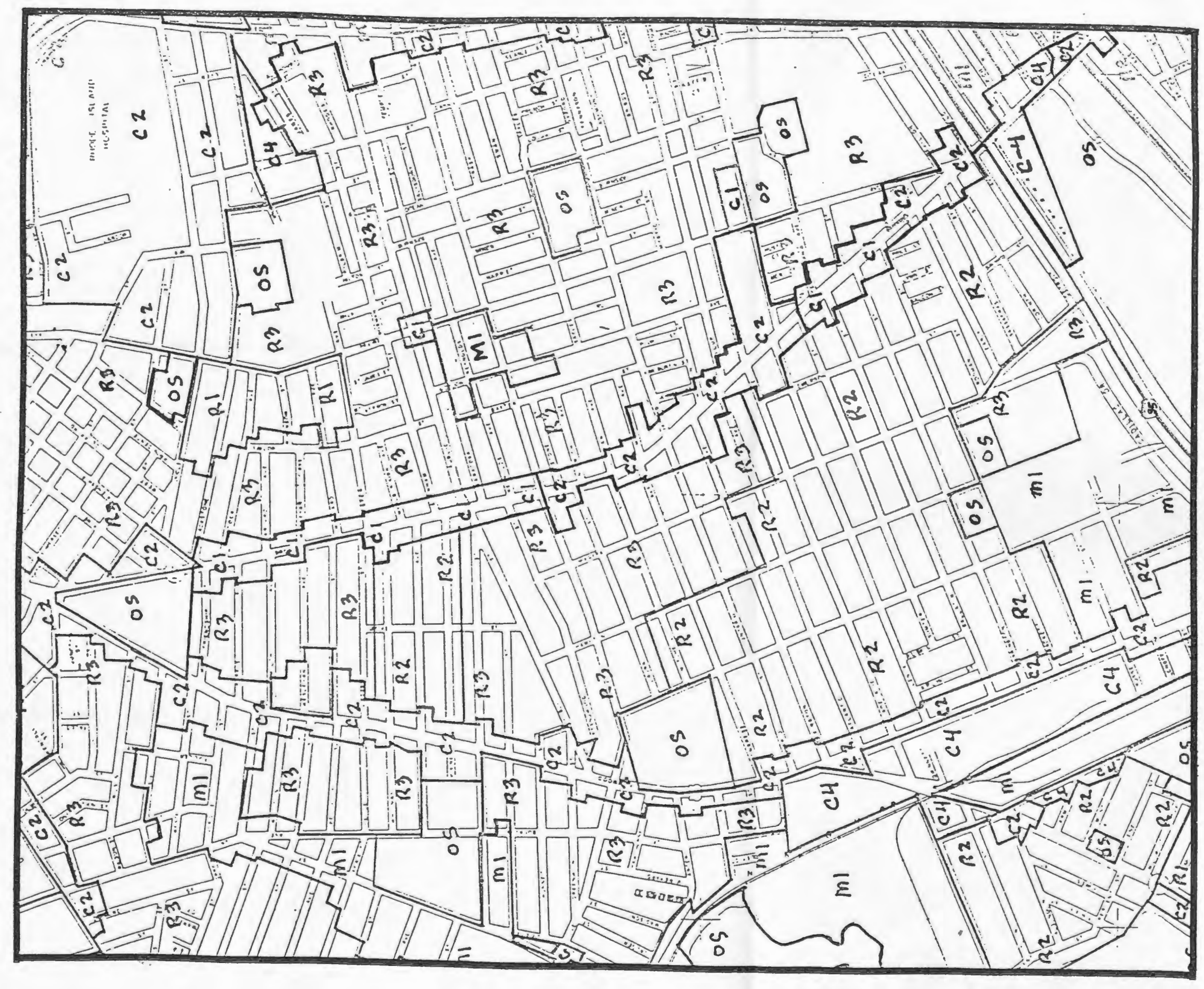

Figure 6

\section{$\underline{L E G E N D}$}

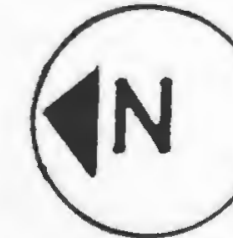

\section{STUDY AREA}

C1

LIMITED COMMER
COMMERCIAL
DISTRICT

C2 general

COMMERCIAL DISTRICT

CITY OF PROVIDENCE 


\section{Section One}

\section{Land Use}

Section One (Figure 7) starts at the intersection of Detroit Avenue and Byfield Street and continues north to Oxford Street and Ontario Street. The length of this section is approximately 3007 linear feet making it the longest of the four sections in the study area. This section provides the entry to Broad Street Commercial District from the south. Essentially, Interstate-95 separates the study area from Washington Park. Facing the west side of the study area is Roger Williams Park, a major focal point as well as a landmark for the City of Providence.

On the west side of Section One is recently opened Providence Auto Company Annex (1149 Broad Street). The office is a newly renovated building. Next to Providence Auto Company Annex is the newly opened Far-East Plaza (1137 Broad Street). The commercial uses at the pedestrian level are Pho Pasteur Restaurant and Saigon Super Market. Its facade is red brick, and in satisfactory condition.

Located on the east entrance of Section One is Parts Plus Auto Store (1146 Broad Street). The exterior of the building has white colored brick, with no significant architectural design.

Next, on either side of the street are car services and repair shops. Caribbean Service Station (1123 Broad Street) is on the west side, and Dynamic Garage Repair Shop (1112 Broad Street) on the east, in a triangular shaped lot. This lot also contains a memorial plaque stone block which might be considered as a possible site for the placing of a logo or banner signifying entry to Broad Street Commercial 

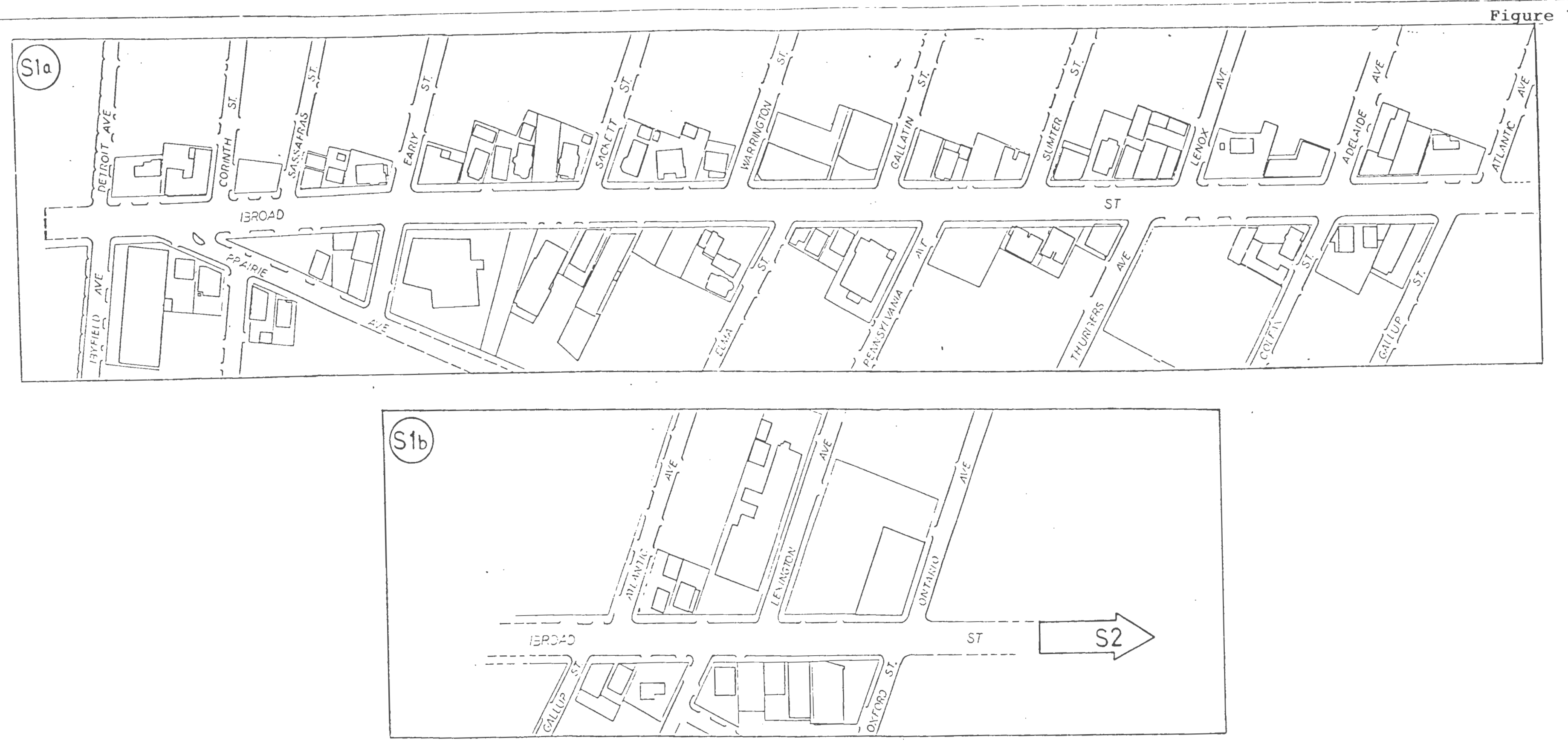

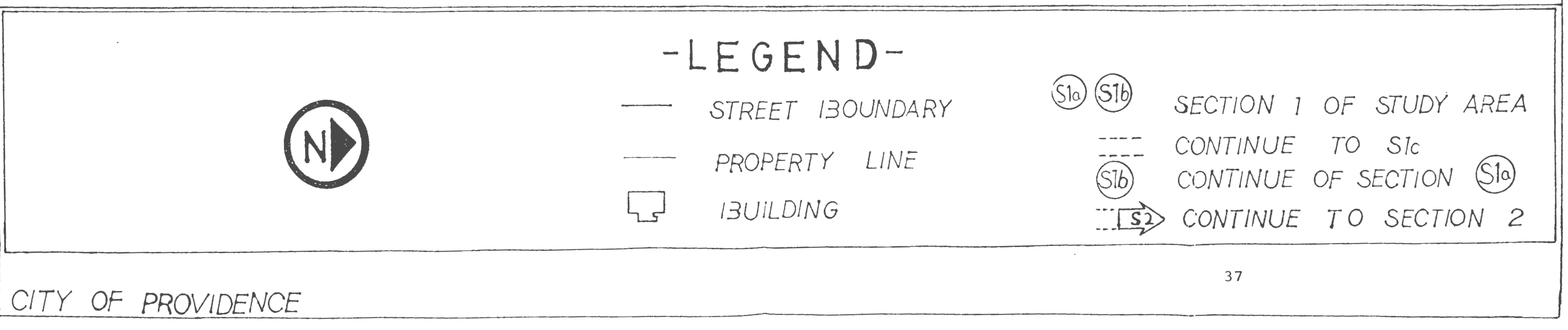


District.

An entire listing of the buildings is contained in Table 5.

Table 5

\begin{tabular}{|c|c|c|c|c|}
\hline & Land Use & Street Number Fa & ade & \\
\hline & 1-CrediAmerica Travel & 1106 Broad St. & B & A \\
\hline & 2-JFK Furniture Store & 1102 Broad St. & B & \\
\hline & 3-Perez Fashion & 1100 Broad St. & B & \\
\hline & 4-New England Telephone & 1094 Broad St. & B & \\
\hline & 5-El Inca Restaurant & 1070 Broad St. & B & \\
\hline & 6-El Inca Night Club & 1070 Broad St. & B & \\
\hline & 7-Norman's Cleaners & 1060 Broad St. & $\mathrm{C}$ & \\
\hline & 8-Mills Coffee Roast Co. & 1058 Broad St. & B & \\
\hline & 9-Funeraria $\mathrm{La} \mathrm{Fe}$ & 1040 Broad St. & B & B \\
\hline & 10-Hernandez Liq. Store & 1032 Broad St. & B & \\
\hline & $11-{ }^{*} \mathrm{R} 2$ & $1028-1030$ B. St. & B & \\
\hline & $12-{ }^{*} \mathrm{R} 2$ & 1020-1022 B, St. & B & \\
\hline & 13-Grace Church & 1014 Broad St. & B & \\
\hline & 14-Brother's Pizza & 950 Broad St. & $\mathrm{C}$ & 3 \\
\hline & $15-{ }^{*} \mathrm{R} 4$ & 966-988 B. St. & $\mathrm{C}$ & \\
\hline & 16-R.I. Meals on Wheels & 924 Broad St. & B & \\
\hline & 17-Bessie's Deli & 912 Broad St. & B & A \\
\hline & 18-San-Francisco Brakes & 910 Broad St. & $\mathrm{C}$ & \\
\hline & 19-Electronic Romana & 908 Broad St. & B & \\
\hline & 20-Ana \& Braulio & 906 Broad St. & B & \\
\hline & 21-Val-Lynn Decorators & 900 Broad St. & B & \\
\hline & 22-L.K. Goodwin Hand. Eq & q. $\quad 890$ Broad St. & B & B \\
\hline & 23-HUD & 882 Broad St. & B & \\
\hline & 24-Oriental S. \& Laundry & 880 Broad St. & $\mathrm{C}$ & \\
\hline & 25-NDS Pharmacy & 866 Broad St. & B & $B$ \\
\hline & & & & \\
\hline & 1-Las Antillas Market & 1115 Broad St. & B & A \\
\hline & 2- * R2 & 1111-1112 B. St. & $\mathbf{A}$ & \\
\hline & 3-Jimenez Real Estate & 1099 Broad St. & B & \\
\hline & 4-Guttin's Bakery & 1089 Broad St. & $\mathrm{C}$ & \\
\hline & 5- ${ }^{*} \mathrm{R} 2$ & 1085-1087 B. St. & $\mathrm{C}$ & B \\
\hline & 6- *R3 & 1079-1081 B. St. & B & \\
\hline & 7-Peria Market & 1061 Broad St. & $\mathrm{C}$ & \\
\hline & 8- *R3 & 1043-1047 B. St. & $\mathrm{C}$ & \\
\hline & 9-Alberto's Hairstylist & 1053 Broad St. & B & \\
\hline
\end{tabular}




\begin{tabular}{|c|c|c|c|}
\hline $10-{ }^{*} \mathrm{R} 2$ & 1041-1043 B. St. & B & E \\
\hline 11-La Famosa Market & 1035 Broad St. & B & A \\
\hline 12-Pito's Restaurant & 1137 Broad St. & B & $A$ \\
\hline 13-Justina Fashion & 1027 Broad St. & B & $A$ \\
\hline 14-Discomando Rec. Shop & 1025 Broad St. & & B \\
\hline 15-Teresa's Discount & 1023 Broad St. & B & $A$ \\
\hline 16-Jason's Furniture & 1015 Broad St. & $\mathrm{C}$ & A \\
\hline 17-Atlantic Auto Supply & 1005 Broad St. & $\mathrm{C}$ & $\mathbf{E}$ \\
\hline $18-{ }^{*} \mathrm{R} 3$ & 1003-1001 B. St. & C & $\mathbf{E}$ \\
\hline 19-Carniceria Market & 991 Broad St. & C & A \\
\hline 20-Amy's Sandwiches & 989 Broad St. & $\mathrm{C}$ & A \\
\hline 21-New England Market & 987 Broad St. & $\mathrm{C}$ & A \\
\hline 22-Apostolic Faith & 977 Broad St. & D & A \\
\hline 23-La Fragancia Club & 975 Broad St. & B & A \\
\hline 24-Lenox Market & 973 Broad St. & $\mathrm{C}$ & A \\
\hline 25-Al Krasner's Garage & 953 Broad St. & $\mathrm{C}$ & E \\
\hline 26-Elsie's Gold & 951 Broad St. & B & A \\
\hline 27-Nunez Liquors & 941 Broad St. & B & A \\
\hline 28-Lan Gran Parada & 937 Broad St. & C & A \\
\hline 29-Glency's Market & 935 Broad St. & $\mathrm{D}$ & $A$ \\
\hline 30-Quisqueya Market & 933 Broad St. & B & A \\
\hline 31-J \& B Laundromat & 1060 Broad St. & B & E \\
\hline 32-Stanley Auto Service & 910 Broad St. & D & $A$ \\
\hline 33-Talbot House Inc. & 903 Broad St. & C & E \\
\hline 34- *R2 & 897-899 B. St. & B & E \\
\hline 35-Tommy's Cozy Grill & 897 Broad St. & $\mathrm{C}$ & A \\
\hline 36-The Ganley Relig. Co. & 891 Broad St. & $\mathrm{C}$ & B \\
\hline 37-Mendez Market & 863 Broad St. & B & E \\
\hline
\end{tabular}

\section{Facade Condition}

Compared to the other commercial districts in Providence, Section One has the lowest number of building in the category of "excellent". Of the sixty-two (62) structures in Section One, a total of thirty-nine were categorized as "satisfactory". A total of twenty (20), were categorized as "minor repairs required". A large number of buildings have large area of deep wear, loose, broken and missing bricks, and 
peeling paint. At the present time, many of the buildings which require minor repairs are vacant.

Most importantly, the section has total of three structures that are listed D "major repairs required". These buildings have large holes, extensive area of loose structure surface, and wide breaks. These buildings should be considered for immediate facade improvement.

\section{Residential}

Like other commercial districts in the City of Providence, the survey revealed that the predominant use in Broad Street is commercial. Most of the commercial businesses in this section have a Hispanic base. However, the survey indicates that there are also eleven residential units( e.g. ${ }^{*} \mathrm{R} 2$ ) in Section One. Most of these residential units are in poor shape, and require major rehabilitation efforts. If careful planning is not taken into consideration, residential units could be replaced by commercial uses in the future.

\section{Circulation and Parking}

Within the section there are series of sub-collector roads(Thurbers Avenue and Sackett Street) which act as a short cut to Elmwood Avenue and Eddy Street. Thurbers Avenue is a major short cut route to Interstate 95.

From observing traffic patterns in the area, both NHD Pharmacy and Mendez Department Store appear to be the two businesses which attract a high number of 
shoppers to their area. Cars are constantly pulling in and out of their parking area. As such, the two parking lots have cracks, and are inadequate for the amount of shoppers they attract.

Considering the existence of sixty-two structures in the section, there are only 37 structures with on street and off-street parking. The number of cars attracted to it exceeds the number of parking spaces. This often results in parallel parking on the street.

\section{Section Two}

\section{Land Use}

Section Two encompasses the area from Oxford and Ontario Streets to Public Street (see Figure 8). The length of Section Two is approximately 1550 linear feet. On the west side of the it is a private rest home ( 859 Broad Street). The structure has unique architectural features of the Colonial Revival Style, and was built in 1897.

Next to the private rest home is the Providence Fire Station (857 Broad Street). On the east side of the street is Carolina Market (864 Broad Street). The second and third floors of Carolina Market are vacant residential units. Recently, the front of Carolina Market had just been renovated, however, nothing was done to the upper floors.

Similar to Section One, the inventory survey indicated the following findings concerning land use and building conditions. The listing in Table 6 contains the findings of that survey. 


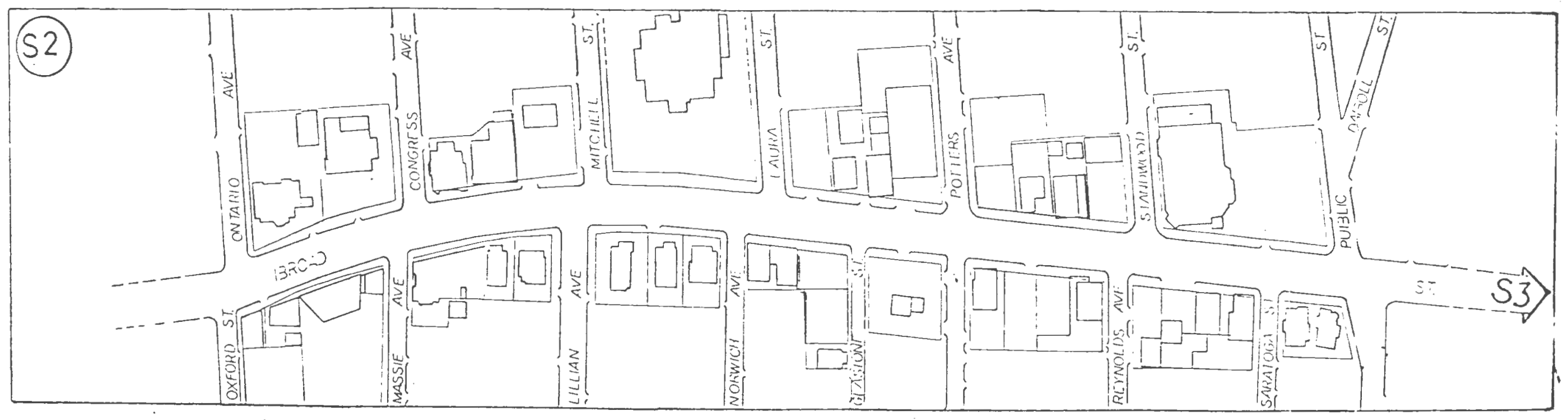

\section{$-L E G E N D-$}

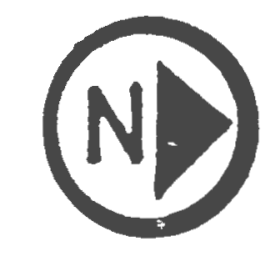

CITY OF PROVIDENCE
STREET IBOUNDARY

- PROPERTY LINE

$\square$ ISUILDING
(5) SECTION 2 OF STUDY AREA ...- CONTINUE FROM SECTION IC

…33) CONTINUE TO SECTION 3 
Table 6

Land Use

Street Number Facade Cond Parking

East

1-Carolina Market

2-J,Pirre Shoes(vacant)

3-Solymar Tours(vacant)

4-La Palma Restaurant

5-Juanda Tailor Shop

6-Un-name commercial

7-Del Septimo Dia Temple

8- *R2

9- *R2

10- *R2

11- *R2

12-Kandy's

13-Papo's Grocery \& Deli

14-Jaquez Party Store

15-Donnelly's

16-Getty's Gas Station

17-Juhlin-Pearson Funer.

18-Tony's Tropical Food

19-Liriano Tailor

20-El Chamo Restaurant

21- *R2

22- * R2

$\underline{\text { West }}$

1-La Gran Via

2-New Heart-Land Baptist

Church(vacant)

3-Un-named commercial

4-Un-named Auto Service

5-Steere House

6-Providence Auto Engin.

7-Tony's Meat Market

8-Armen's Hardware Co.

9-Sandra's Beauty Supply

10-Providence Market

11-Calvary Baptist Church

$\begin{array}{lll}864 \text { Broad St. } & \text { B } & \text { A } \\ \text { 860 Broad St. } & \text { B } & \text { A } \\ \text { 858 Broad St. } & \text { C } & \text { A } \\ \text { 856 Broad St. } & \text { D } & \text { A } \\ \text { 850 Broad St. } & \text { D } & \text { A } \\ \text { 848 Broad St. } & \text { D } & \text { A } \\ \text { 848 Broad St. } & \text { D } & \text { A } \\ \text { 828-830 B. St. } & \text { B } & \text { B } \\ \text { 824-826 B. St. } & \text { C } & \text { B } \\ \text { 808-810 B. St. } & \text { D } & \text { B } \\ \text { 804-806 B. St. } & \text { D } & \text { B } \\ \text { 798 Broad St. } & \text { B } & \text { A } \\ \text { 796 Broad St. } & \text { B } & \text { A } \\ \text { 794 Broad St. } & \text { B } & \text { A } \\ \text { 790 Broad St. } & \text { B } & \text { B } \\ \text { 788 Broad St. } & \text { D } & \text { B } \\ \text { 754 Broad St. } & \text { B } & \text { B } \\ \text { 740 Broad St. } & \text { C } & \text { B } \\ \text { 746 Broad St. } & \text { C } & \text { A } \\ \text { 736 Broad St. } & \text { C } & \text { A } \\ \text { 728-730 B. St. } & \text { B } & \text { B } \\ \text { 724-726 B. St. } & \text { B } & \text { B }\end{array}$

833 Broad St. $\quad$ C A

831 Broad St. D A

829 Broad St. D A

825 Broad St. C B

807 Broad St. B B

773 Broad St. B B

769 Broad St. B $\quad$ B

763 Broad St. B

761 Broad St. B A

757 Broad St. B B

755 Broad St. $\quad$ B $\quad$ B

As listed, the uses at the end of Section Two are Calvary Baptist Church on the 
east side and a two family unit (726 Broad Street) on the west side. Calvary Baptist Church provides an important buffer for the intersection. Essentially, it occupies the entire frontage lot. Importantly, it brings peace to the community. The two family house on the opposite right side also act as a buffer for the area. The house needs minor painting and some landscaping.

Section Two could be described as an area which contains a wider mix of uses and less Hispanic influence. The main characteristic of Section Two is that it has a more scattered and inconsistent pattern of development.

\section{Facade Condition}

Within Section Two, there are a total of 33 buildings. Out of these structures, there are a total of 16 categorized as "satisfactory". There has been repair work done on the street level floors but not on the second stories. There are a total of eight structures in need of minor repairs. This section has a higher number of buildings listed under "major repairs required" compared to Section One. The area has a total of nine buildings that need major repairs.

\section{Residential}

Within Section Two, there are seven residential housing units. Similarly, these residential units vary in their facade conditions. Out of the seven residential units, three are categorized as "satisfactory", one is in the category of "minor repairs required", and two require major repairs.

\section{Circulation and Parking}

Approaching Section Two from the south end is a signal light, which slows 
down traffic entering the area. The busiest intersection within Section Two lies within the intersection of Potters Avenue and Broad Street. There are a total of sixteen buildings that have both on and off street parking. Due to the low concentration of businesses within this section, parking does not seem to be a problem.

\section{Section Three}

\section{Land Use}

Section Three begins at Public Street and continues to Wesleyan Avenue (Figure 9). Its length is approximately 1230 linear feet. The activities within this area have almost no Hispanic influence compared to Sections One and Two.

On the west side entering Section Three is a newly built commercial building which opened in 1990. This building contains Rite Aid Pharmacy (713 Broad Street), Tip Top Laundromat (711 Broad Street), Gold Pot Chinese Food (709 Broad Street), and Jean Carlo's Deli (707 Broad Street).

These new commercial activities have brought many positive impacts to the neighborhood. However, their negative impacts were much greater. They changed the characteristic of Broad Street by making it similar to other typical commercial strips. The odd square shape and facade of the building does not fit the surrounding historical structures.

On the west side of Section Three is Brite-Nu Cleaners. The facade of the building is painted red. The signs are old and dilapidated. The building needs minor repairs. From the survey, the following uses were identified: 


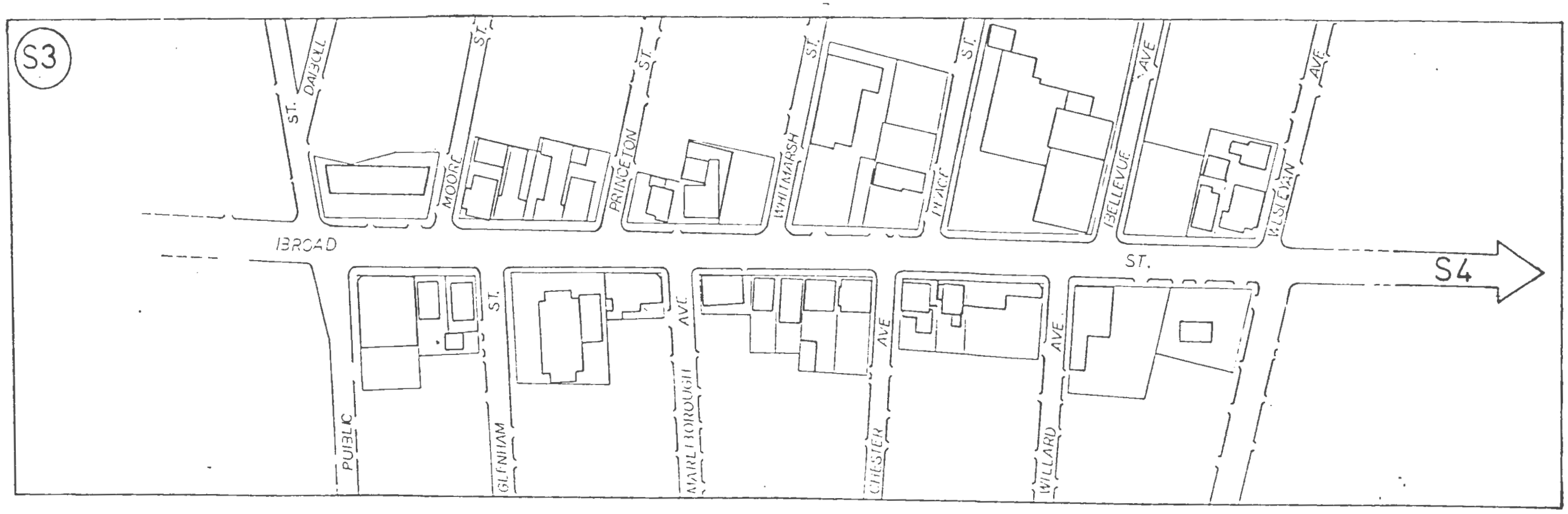

\section{- LEGEND -}

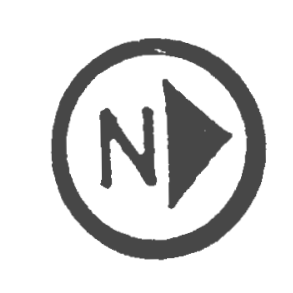

- STREET IBOUNDARY

(33) SECTION 3 OF STUDY AREA

PROPERTY LINE

… CONTINUE FROM SECTION 2

ऽ BUILDING

S4 CONTINUE TO SECTION 3 


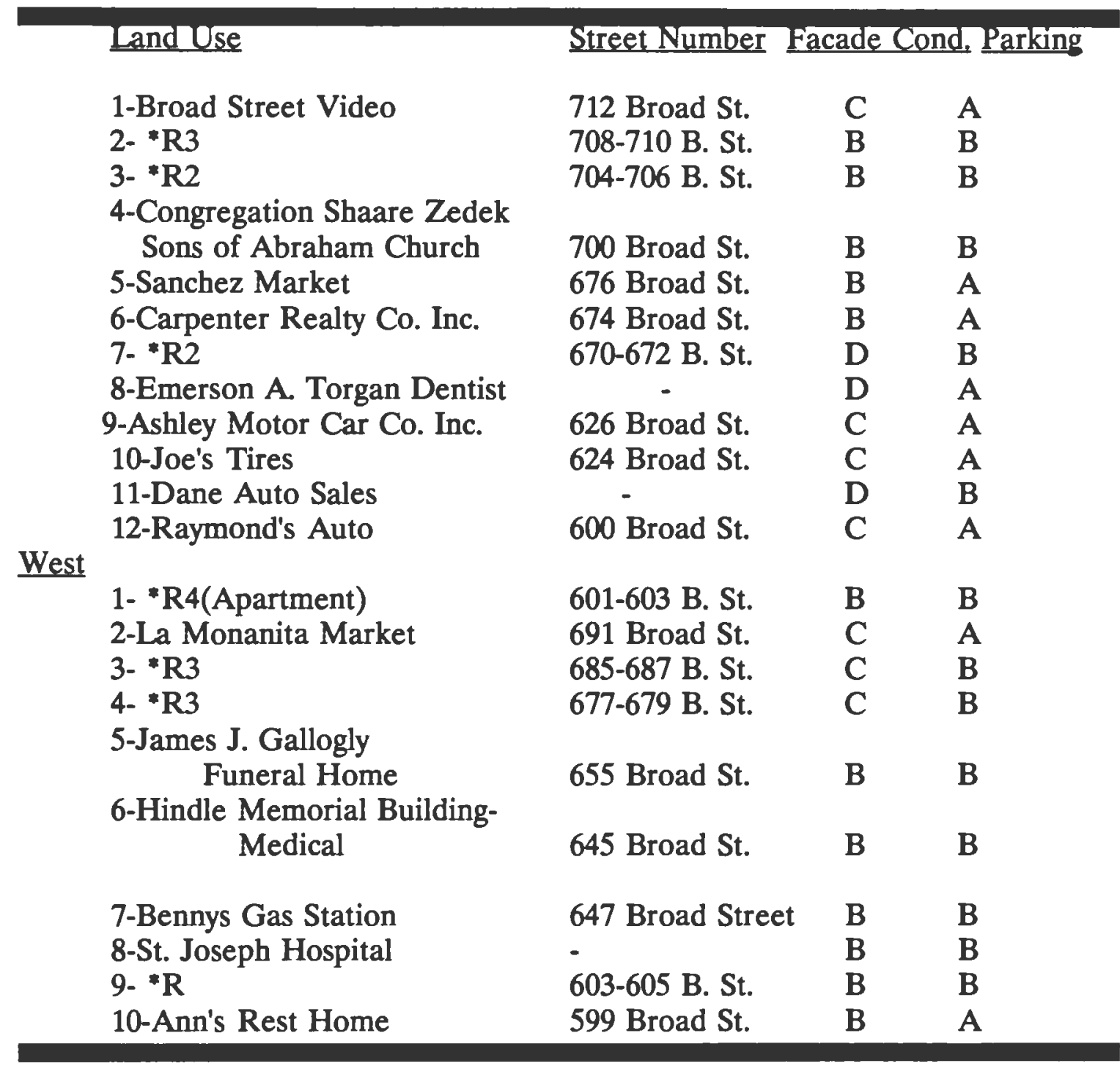

\section{Facade Conditions}

At the end of Section Three lies Ann's Rest Home on the west side and Raymond's Auto on the east. Ann's Rest Home is in satisfactory condition. The building needs minor exterior paint. However, Raymond's Auto is in poor condition. The facade is dilapidated and in need of major clean-up. Its fences are bent and 
rusted; asphalt cracked, and the roof is falling apart. There are also numerous dilapidated and vacant buildings within Section Three.

The survey revealed numerous important findings. There are a total of twenty-two buildings in the section. Of the twenty-two, there are a total of twelve buildings categorized as satisfactory; seven buildings as "in need of minor repairs"; and three structures as "major repairs required". Importantly, the west side of this section is much cleaner then the east side due to the fact that the buildings in need of major repairs are located on the west side.

The section has many historical homes. If renovated, these could attract new uses to the area. In addition, included in the section is Saint Joseph Hospital. It is a strong entity for the neighborhood and has been serving the surrounding neighborhoods since 1965.

\section{$\underline{\text { Residential }}$}

There are seven residential units within the section. A majority of them are in poor condition. Efforts should be made to preserve these residential units.

\section{Circulation and Parking}

Traffic within the area is not as congested as in Section One. Within the section there is a signal light at the intersection of Peace Street and Broad Street. Of the twenty-two buildings, there are only thirteen which have accessible on and off street parking. 


\section{Section Four}

\section{Land Use}

Section Four begins at Wesleyan Avenue and continues north to Hayword Street (see Figure 10). The length of the area is approximately 1750 linear feet. The section provides entry to Trinity Square. This section has a history that goes as far back as 1879 . Some of the early settlements in the City of Providence were along Section Four. The section has many historical homes. At the present time, there are still some Victorian homes in the area.

At the end of Section Four is Grace Church cemetery-on the west side. Within the same lot is Elmwood Preservation Commission on the front. This section provides entry to Broad Street from the north. Upon entering is Trinity Square, and in the middle of intersection is a triangle shaped block which should be considered as a possible site for the placing of a logo or banner signifying entry to Broad Street.

The survey also revealed the following exist uses in Section Four (Table 8):

Table 8

East

Land Use

1-Sabet's Pizza

2-Princess Boutique

3-Residential

4-Broad Street Auto

5-General Armature

Service Inc.

6-Vacant commercial

7-Reymon's Tailor

8-Perf. Sound Alarm

9-Botanica Pedro

10-Mi Casita
Street Number Facade Cond. Parking

570 Broad Street B B

568 Broad Street B B

B B

514 Broad Street B B

516 Broad Street B B

- C A

506 Broad Street B A

504 Broad Street B A

502 Broad Street B A

500 Broad Street B A 


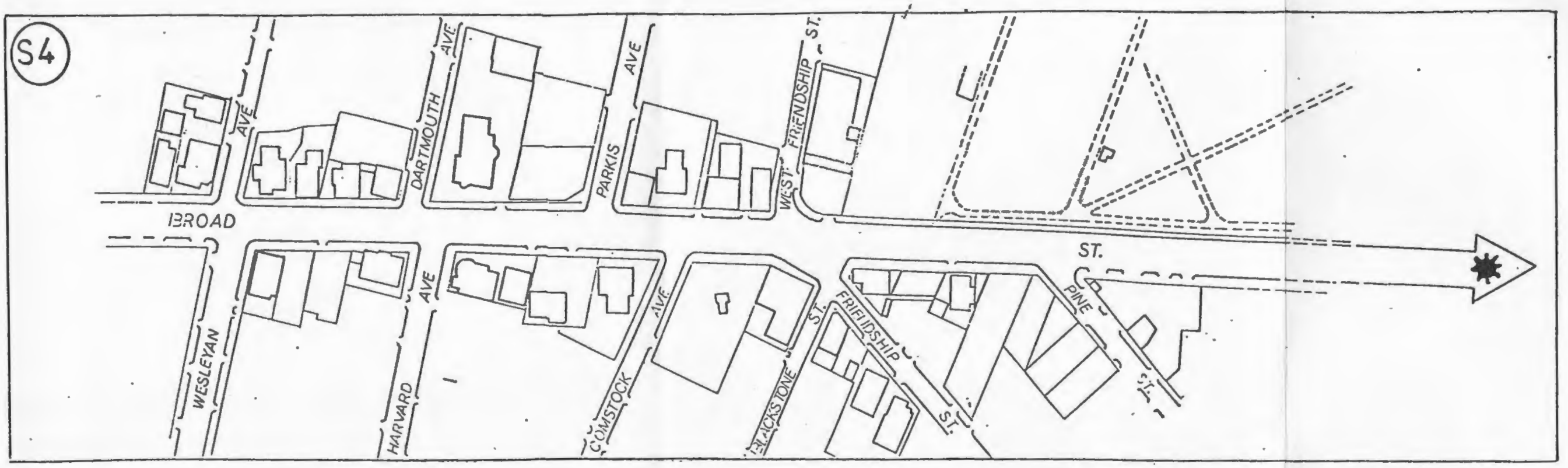

\section{- LEGEND-}

(14)

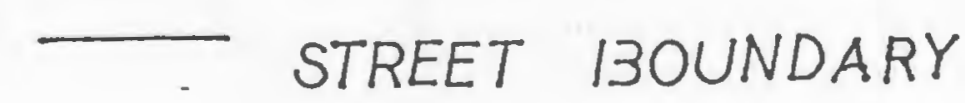

PROPERTY LINE...

$\because$ ISUILDING
(54) SECTION 4 OF STUDY AREA -...- CONTINUE FROM SECTION 3 ACCESS TO DOWNTOWN 


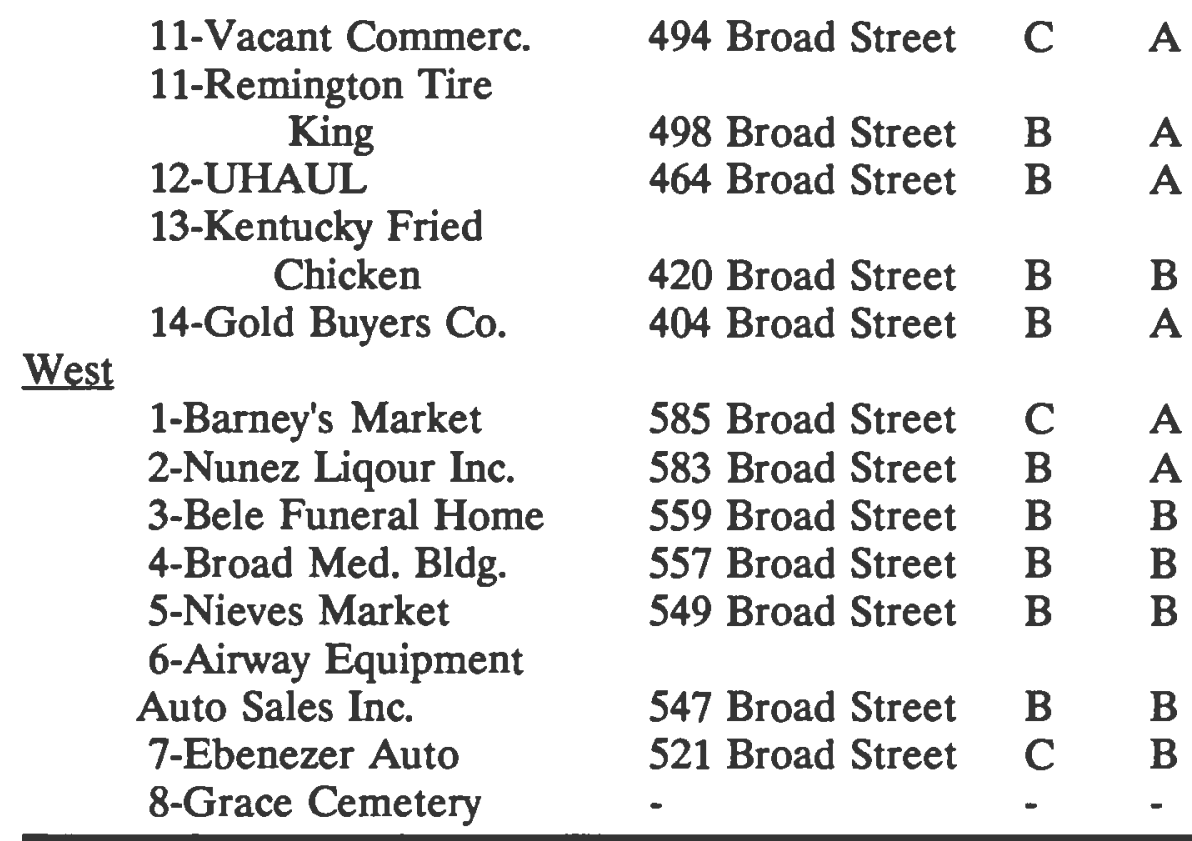

\section{Facade Condition}

On the west side entering Section four is a two family house, number 591-593. It is yellow painted and in need of minor repairs. Next door to the residential unit is Nilsa Fashion (587 Broad Street). Its facade is painted white. The building is too small for its activity. The area around it is in need of cleaning.

Within Section Four there are 22 buildings. Of the 22 buildings, 18 were categorized as "satisfactory". Four buildings were categorized as "minor repairs required".

\section{$\underline{\text { Residential }}$}

There are only four residential units within Section Four. All of which has historical characteristics. Each is in need of major renovations. 


\section{Circulation and Parking}

The two important sub-collector roads, Friendship and Pine Streets, both are one-way streets. Friendship Street provides a short cut to Interstate-195 and Pine Street provide access from downtown. Of the 22 buildings, only 11 which have off street parking. The remainder have only on street parking.

\section{Summary of Findings}

Broad Street, one of Providence's oldest streets, has undergone tremendous changes in the last several decades. In conducting the survey, the street has some of the largest collection of goods and services which come from all over the world. This

influence is a reflection of the fact that the area receives the largest in-migration of minorities in the City.

In recent years, Broad Street has undergone a downturn in its economy. Driving along Broad Street, one can see many buildings in poor condition. The general condition of the structures in Broad Street includes dilapidated structures, poor and deteriorating signs, peeling of exterior paint, cracked sidewalks, vacant and boarded up residential and commercial buildings, and vacant lots. The area is also experiencing many social problems such as drug activity, street gangs, and crime.

Recently, there has been an increase in traffic entering and leaving on Broad Street. The volume and flow of traffic on Broad Street has some effect on the market potential of various businesses. However, with the improvement of both the economy and social conditions, Broad Street businesses would be strengthened in the 
future.

Broad Street commercial businesses are owned predominantly by working class residents living in South Providence and Elmwood. Like many other inner city commercial corridors, Broad Street has its share of problems: dilapidated and boarded up residential buildings, abandoned commercial structures, low percentage of home ownership, crime and vandalism, and other signs of growing blight. Mixed and incompatible land uses have prevailed in the area causing a downward trend in the Broad Street Commercial activities.

Recently, small and family owned businesses in Broad Street had been reacting to neighborhood decline alone, without initiating progressive action to address their problems. There was little, or no, interaction from the higher level officials or government. The response has all to often been the result of each individual business owners feeling that their survival depends solely on their own ability and effort.

The experience of driving along Broad Street makes one realize the problems a unique main street within the City of Providence is experiencing. Although the street has some of the most negative experiences of any street, it has got a lot of potential. Until these potentials are discovered and put into good use the problem would get worse. 
CHAPTER FOUR

REVIEW OF PLANNING DOCUMENTS 


\section{INTRODUCTION}

The City of Providence has, over the years, enjoyed both prosperity and wealth. There are a total of twenty four neighborhoods within the City. Over the years, there have been numerous revitalization plans done by the Providence Redevelopment Agency and the Department of Planning and Development. The purpose of these plans was to offer measures and strategies to enhance the positive aspects and remove the negative effect on the commercial streets within the City.

This chapter will review neighborhood revitalization plans prepared by the Department of Planning and Development and the Providence Redevelopment Agency. The plans will be used as a basis for comparison of past redevelopment strategies. These plans will provide a background for developing revitalization strategies and guidelines for future development plan within the City of Providence.

The three revitalization plans which will be used as the base for discussion are: 1) The Mount Pleasant Business District Revitalization Plan-1990, 2) DePasquale Avenue-Federal Street Target Area-1989, and 3) Upper South Providence Proposed Redevelopment Plan-1984. The objective is to discover from each revitalization plan the following:

1) Who did the plan and for what purpose?

2) What were the goals of the plan?

3) What are the issues, elements, and criteria important for revitalization? 
The objective of this chapter is to review the three revitalization plans and seek the answers for the following questions:

1) Did all the plans included the same issues, funding, and implementation strategies, etc..?

2) Was there party(ies) or board(s) involved to carry the implementation of the plans?

3) Did the plan get implemented?

4) What did all the plans lack?

\section{The Mount Pleasant Business District Revitalization Plan}

The Mount Pleasant Business District Revitalization Plan was completed in 1990 by the Department of Planning and Development of the City of Providence. The purpose of this project was to develop a model for the revitalization of the Mount Pleasant Business District:"to assist local business districts in preservation, revitalization, and economic strengthening. In addressing these concerns, a comprehensive approach has been developed. The process offers measures to enhance the positive aspects and remove the negative, thereby developing a climate to bring the business district to its highest potential."(City of Providence,1990:1)

The goals for the City's Neighborhood Business District Program are:

1-To reenforce and rekindle the economic vitality and strengthen the 
economic potential.

2-To stabilize the residential neighborhood through strengthening the commercial area.

3-To enhance the quality of life for area businessmen and residents.

4-To enhance the visual quality of the area for shoppers.

5-To develop imaginative use of business and government resources.

6-To develop centralized management for the business district.

7-To promote the unique character of the business district.

8-To provide a mixture of retail and service enterprises.

9-To establish design criteria for appropriate development.

To make the Mount Pleasant Business District more successful, the study recommended the public-private cooperation. Included in the revitalization plan are four sections containing the various issues, strategies, and model for preparing the plan. The following is a list of important criteria for revitalization developed by the Department of Planning and Development.

\section{Inventory and Analysis}

The study area surveyed for existing land use, zoning, property ownership, 
building condition, historic character, and public rights-of-way. The existing land use was surveyed to project trends in the future. Zoning is a basic planning tool that regulates and control the expansion of non-conforming uses and density. The following categories were identified from studying of existing land use:
a) Commercial
b) Mixed-use
c) Residential
d) Institution
e) Open space

The existing zoning within the study area consisted of 1) R-2, residential two family zone, 2) R-3, residential three family zone, 3) C-1, limited commercial zone, 4) C-2, general commercial zone, and 5) C-4, heavy commercial. Parking and circulation was studied to plan for a safe and efficient flow of traffic as well as adequate and convenient parking. Also in this section were inventory describing existing conditions and historic character. As mentioned, the purpose of doing the inventory and analysis is to identify the strengths and weaknesses of the retail areawhich in turn reflect its vitality.

\section{The Plan}

"The approach of the Providence Neighborhood Business District Program is based not only upon revitalization through physical improvements but also on a 
revitalization "process" which includes centralized management. The plan reflects that theory in three components: 1) Organization of the Business District; 2) Streetscape Improvements; and 3) Policy Recommendations." (City of Providence,1990:25) Importantly, the program is based upon the Main Street approach to revitalization sponsored by the National Trust for Historic Preservation. The model was developed as a comprehensive strategy that would preserve the downtown and neighborhood commercial districts and revive their economy.

As indicated, the first component of the Providence Neighborhood Business District Program is organization. The approach emphasizes the importance of the private sector in the management of the business district and storefront renovation. For the private sector, specifically, the following process was recommended by the Department of Planning and Development:
a) Business Advisory Committee
b) Management Office
c) Promotion
d) Design
e) Economic Strengthening

The second component of the program is streetscape improvements. As such, the following improvements will be carried out by the City:

a) Sidewalk Repairs 
b) Power Line Consolidation

c) Street Tree

d) Landscapes Sitting Area

e) Bus Shelter Relocation

f) Street Surface Improvements

g) Public Sitting Areas

h) Gate Signs

i) Business District Logo

The third component of the program includes policy recommendation. These are policy improvement, zoning changes, building reuse, design, construction, and maintenance.

\section{Implementation}

The implementation section is divided into three different phases, specifically for infrastructure improvements and provision of technical assistance. The three phases make up schedule for improvements which are contingent upon the availability of adequate funding and the evidence shown by the private sector to contribute to the realization of project goals. The funding sources which the City of Providence will utilize for the implementation of the plan are: 1) Community Development Block Grant(CDBG) Funds, 2) City of Providence Low Interest Home 
Improvement Program, 3) City of Providence Rental Rehabilitation Program, 4) Providence Economic Development Corporation Revolving Loan Fund, and 5) Providence Street Tree Program.

DePasquale Avenue-Federal Street Target Area, Amended to the Federal Hill East Redevelopment Project.

The DePasquale Avenue-Federal Street Target Area project was completed in November 1989 by the Providence Department of Planning and Development. The purpose for the undertaking of this project was "an effort to clearly understand the issues and constraints so that the study group could develop an effective plan for revitalization."(City of Providence,1989:1) Presumably, there was growing concern for the neighborhood and its residents, signs of blight and deterioration had become more and more evident in the DePasquale Avenue-Federal Street Target Area.

One aspect of the plan was to improve the housing stock and encourage development of new housing in the DePasquale Avenue-Federal Street Target Area. Essentially, the goal was to stabilize the housing stock by promoting homeownership, acquisition of a number of properties, infrastructural improvements, and the development of additional owner-occupied two-family dwellings. The DePasquale Avenue-Federal Street Target Area contained numerous important issues which were studied for the redevelopment project. The following is a list of important criteria for the revitalization of the area developed by the Providence Department of 
Planning and Development.
a) Existing Land Use
b) Building Conditions
c) Present Zoning
d) Property ownership
e) Development Plans for the area
f) Historic character

The following is a list of important criteria for revitalization by the Department of Planning and Development.

\section{Inventory and Analysis}

The DePasquale Avenue-Federal Street Target Area is a densely developed block in the City of Providence. The Project area has a wide mixed of uses. The following uses were identified from the study:
a. Residential
127 structures
b. Mixed Use
9 structures
c. Commercial
7 structures
d. Institutional
4 structures
e. Vacant Undeveloped
20 lots
f. Paved Parking
5 lots 
At the time, the following building conditions were identified:

$\begin{array}{ll}\text { Excellent } & 7 \text { structures } \\ \text { Good } & 49 \text { structures } \\ \text { Deteriorated } & 73 \text { structures } \\ \text { Dilapidated } & 10 \text { structures }\end{array}$

The existing zoning within the target area consisted of $7 \%$ of commercial C-2 zone, while the remaining $93 \%$ is in a residential R-4 zone. Property ownership in the target area is relatively low, and the percentage of home ownership decrease each year. Of the 127 residential structures, only 46-or 36\%-are owner-occupied, leaving $64 \%$ of the structures owned by absentee landlords.

The overall condition of public rights of ways is classified as being in poor condition. Included in the target area are two parcels which belong to BroadwayArmory National Historic District. Both uses are classified as in deteriorated condition.

The Plan

Through the analysis of existing conditions within the DePasquale-Federal Street Target Area, a set of goals for revitalization was established:

-To çurb and reverse blighted conditions;

-To strengthen the economic potential of the area;

-To provide additional housing possibilities; and 
-To stabilize the neighborhood.

The data collection phase of the study revealed that the most negative influences in the DePasquale-Federal Street Target Area are the blighted vacant lots, dilapidated structures, and mixed uses. As such, the above goals can be realized by using of several redevelopment tools including acquisition, disposition, and rehabilitation. Included in the plan was the road improvements by the City of Providence. Zone changes were proposed with extension of C-2 zoning along DePasquale Avenue and Federal Street.

\section{Implementation}

Included in the revitalization plan is also a list of implementation strategies outlined by the Department of Planning and Development.

-Acquire property and eliminate substandard structures which are infeasible for rehabilitation and prepare land for construction of duplexes with sufficient parking;

-Establish residential design criteria consistent with existing architecture;

-Provide business loans through the City's PEDC Revolving Loan Fund;

-Providence site improvements to public rights of way through a coalition of the Department of Planning and Development, public Parks and Public Works Department; 
-Enforce housing code requirements with coordinated efforts of the City's Building Inspector and the Providence Housing Court; and -Assemble an Advisory Committee whose members would represent both the private and the public sectors.

Like any other plan, funding is always a major issue. The project will be funded through proceeds collected from Silver Spring Industrial Park land sales. The cost estimates would be $\$ 944,408$.

\section{Upper South Providence, Proposed Redevelopment Plan}

The Upper South Providence Proposed Redevelopment Plan was completed in 1984 by the Providence Redevelopment Agency. The plan was the product of several years of planning by the South Providence Community Board (SPCB) as the official project area planning committee. Over the years, Upper South Providence had suffered a major changes in its housing stock. The area did not show signs of accelerated residential and commercial development. Basically, the most negative influences in the area were the blighted vacant lots and dilapidated structures. For many residents within the City of Providence, Upper South Providence was considered as the least liveable part of the City. "The project goals evolved from a need to discontinue the demolition process of housing which results from disinvestment and deterioration of the existing housing stock. While new housing 
construction would be encouraged, the community's first obligation to its residents is to encourage re-investment in housing. The second obligation is to encouragement of new commercial enterprises."(City of Providence,1989:2)

Given the stated goals, the project objectives were stated as follows:

-To establish an interest subsidy housing rehabilitation program.

-To allow owner-occupied housing a one-year exclusive right to use housing rehabilitation funds.

-To acquire sites for commercial re-use.

-To acquire vacant properties around the Dudley Street Recreation Center.

-To provide for site improvements with both state and federal highway funds.

The three part strategy proposed included: 1) a revitalization effort that concentrated in an area bounded by Dudley Street, Prairie Avenue and Blackstone Street; 2) a revitalization strategy that introduce a comprehensive rehabilitation program to restore the many deteriorated and abandoned residential structures; 3 ) to relocate existing structures to other vacant sites wherever the plan calls for acquisition.

In reviewing the project, the following elements were included as important criteria for revitalization by the Providence Redevelopment Agency:

\section{Inventory and Analysis}

The uses within the Upper South Providence Redevelopment Project are 
predominantly residential in character. The residential structures are two and three story wood frame buildings. Within the Project area are also many vacant lots due to years of building deterioration. Other significant uses in the project area are institutions which include Flynn Elementary School, Rhode Island Hospital, and the Dudley Street Center. The project area is comprised of a total of 234 acres. The following uses were identified from studying of the existing land use:

USE

a) Residential

b) Commercial

c) Industrial

d) Institutional

e) Vacant (improved \& unimproved

f) Public

g) Street
ACREAGE

48.46

7.39

17.40

44.04

54.42

4.85

57.52

234.08

\section{PERCENTAGES}

$20.70 \%$

$3.16 \%$

$7.16 \%$

$18.82 \%$

$23.25 \%$

$2.07 \%$

$\underline{24.57 \%}$

$100 \%$

The recent survey by the Providence Redevelopment Agency revealed the following buildings condition within the Project area. 


\section{BUILDING CONDITION}

a) Excellent

b) Good

c) Satisfactory

d) Light Deterioration

e) Advanced Deterioration

f) Heavy Deterioration

g) Dilapidated
NUMBER

41

89

108

170

94

23

34

559

\section{PERCENTAGES}

$7.33 \%$

$15.92 \%$

$19.32 \%$

$30.41 \%$

$16.81 \%$

$4.11 \%$

$6.08 \%$

$100 \%$

The findings revealed that of the 559 structures, 469 structures or $84 \%$ are residential. As described, residential renovation is the main focus of the plan.

\section{The Plan}

The data collection phase of the study revealed a high percentage (27\%) of the structures having advanced deterioration, heavy deterioration, and dilapidation. There were a total of 321 structures or $57.4 \%$ that were categorized as deficiencies. Through the inventory and analysis of existing conditions within the Upper South Providence Project area, a set of objectives and proposed treatment was established: 
-To institute a comprehensive rehabilitation program in the area.

-To provide development opportunities on specific parcels that are currently under-utilized or certain structures that are substandard or whose uses are not compatible with adjacent uses or which do not meet the concept plan's overall objectives.

-To provide site improvements to include traffic improvement at designated sites but not excluding any future improvement.

-To acquire or rehabilitate certain land and buildings which are either in substandard or in deteriorating condition or that contain uses which are not compatible with adjacent properties.

-The acquired property will be offered for new development consistent with the objectives and controls of the Plan.

-The Site Improvement proposed for the Projects will first consider the intersections of Dudley Street and Prairie Avenue and Public Street and Prairie Avenue.

Other significant factors contained in the plan include proposed general land use. It is the intent of the redevelopment plan to reinforce those uses which have proved their suitability through longevity in a given area. The major land use for the Project shall remain basically unchanged. 


\section{Implementation Strategies}

At the time, the Project Area qualified for urban renewal within the meaning of Section 45-31-8 of the General Laws of the State of Rhode Island. The Urban Renewal technique that was used to achieve the plan objectives included acquisition and clearance, rehabilitation, and non-residential rehabilitation standards. The additional agency functions were a) acquisition of property, b) relocation of families and business, $c$ ) relocation of structures to agency owned vacant land, d) installation and construction of site improvements, e) disposition of agency properties, f) rehabilitation loan program, and g) acceptance from the City of donations of land, site improvements, supporting facilities, cash grants-in-aid, services and other cooperative activities necessary to the execution of this Plan, which the City, under the terms of the same statute, is empowered to contribute with or without consideration to the program undertaking.

Within the redevelopment plan, the proposals include 1) zoning modification, 2) proposed acquisition of lots, and 3) site improvements. Land disposition include standards and controls of C-2 General Commercial Zone, signs, off-street parking, screening, and landscaping and on-site improvements and maintenance for land development.

Other provisions necessary to meet local objectives include

1) Conformity to general plan;

2) Method of relocation; 
3) Other conditions, covenants, restrictions and provisions controlling the development and the use of acquired land and improvements;

4) Miscellaneous provisions;

5) Obligations to be imposed on developers;

6) Duration and effective date of regulations and controls;

7) Estimated cost of redevelopment and proposed method of financing. The estimated Project cost of $\$ 1,200,000$ will be provided from the proceeds from the sale of long-term general obligation bonds from the City for Redevelopment purposes.

\section{Summary of findings}

In reviewing the three revitalization plans done by the City of Providence, there were many important findings. As such, the success of future developmental plans depends on historical background and a review of plans previously undertaken. The findings hopefully will provide a background for developing effective revitalization strategies and guidelines for future developmental plans within the City of Providence. As indicated, the objectives of reviewing and studying of the above revitalization plans was to seek the answers for the following questions:

I. Did all the plans included the same issues, implementation strategies, funding, etc.?

A component for the success of the plans undertaken depended on the inventory and assessment of the study area. The three revitalization plans reviewed 
had covered an equal number of issues. However, in some cases, they lack the basic steps or discussion for implementation. The implementation strategies of Upper South Providence are not as clearly defined as the Mount Pleasant Business District Target Area.

II. Was there a party(ies) or board(s) involved to carry the implementation of the plan?

In the revitalization process, it is very important to have an agency or party responsible for implementation. In each case there was no party or board formed for this purpose. The funding source for the Upper South Providence Proposed Redevelopment Plan was terminated and, at the present time, there is no one who will consider to carry on the plan. There should be other alternative sources of funds if somehow, the funds intended for the project did not get through. At the present time, the Planning Department is in the process of negotiating funds for the implementation of both the Mount Pleasant Business District Revitalization Plan and DePasquale-Federal Street Target Area.

III. Did the plan get implemented?

A major portion of the implementation strategies Upper South Providence was not implemented due to the termination of Urban Renewal funds, and lack of City involvement. At the present time, the DePasquale Avenue-Federal Street 
Target Area Plan and the Mount Pleasant Business District Revitalization Plan are under the process of acquiring funds.

IV. What did all the plans lack?

Importantly, there is no one model that could be use for the revitalization of residential or commercial districts. The lack of a model is an important consideration. Due to the reasons that one section of the City is unlike the others, there should be specific guidelines that could be used for the revitalization of all neighborhoods. As mentioned, the three plans lack the basic steps for implementation. It is important to have one central agency who will be in charge of all plans. Also, there should be greater coordination among different departments in the City.

It can be concluded from the previous analysis that there need to be a more comprehensive approach to the development of future revitalization plans that address the different functional areas, particularly commercial and residential, within the City of Providence. Moreover, there need to be guidelines. Significantly, there needs to be one central agency which has the power to implement the plans. 
CHAPTER FIVE

REVITALIZATION GUIDELINES 


\section{Introduction}

The purpose of the final chapter of this document will be to present a set of revitalization guidelines to be considered for the Broad Street Commercial District. It is basically a seven step approach to revitalization which is divided into three phases.

These guidelines were developed from three resources. First, the issues and concerns which were formulated as a result of this research project. Second, a model for community revitalization and preservation developed by Harry Launce Garnham in his book Maintaining the Spirit of Place. Third, the revitalization criteria which has been established by the City of Providence and its Department of Planning and Development.

This approach was developed with several considerations in mind. First, was to produce guidelines which will assist both businesses and interested citizens in the revitalization process. Second, was to provide a step by step approach to revitalization which is task oriented to allow for easy identification of successes. Finally, this approach was developed so that other business districts within the City which have had revitalization plans prepared for them by the Department of Planning and Development could utilize this document in developing their own strategies for revitalization. 


\section{Phase One}

This initial phase of the revitalization process is divided into two steps, 1) the formation of a revitalization committee, and 2) having the Broad Street Commercial District designated as a redevelopment area.

The goal of Phase One is to create an awareness of the commitment which neighborhood residents and business owners have to the Broad Street Commercial District and its continued development. It will also serve as a way of encouraging a renewed responsibility on the part of the City of Providence to address the economic hardships that some of its neighborhoods have been experiencing.

To get this phase started it will be necessary for a group within the community who is interested in the commercial revitalization of the area to sponsor a workshop or kick-off meeting. The purpose of this workshop will be to invite individuals to participate in the planning process for the commercial revitalization of Broad Street. This meeting should be open to all members of the Broad Street community including business owners, residents, and public officials.

Step One - Formation of a Broad Street Commercial Revitalization Committee

The Broad Street Commercial Revitalization Committee (BSCRC) should be composed of about 15 to 20 persons. Individuals who should be encouraged, or asked to participate might include or represent: 
1. Business Owners

2. Community Interest Groups

3. Professionals

4. Community Leaders

5. City Officials

6. Department of Planning and Development

7. Historical Preservation Groups

8. Local Schools

9. Concerned Citizens

10. Local Ethnic Groups

When recruiting for this committee it is important to be careful to get a good mix of individuals. This will ensure that the needs of the entire community are being represented.

While these individuals do not necessarily always have to share the same view point on all issues, it will be important for them to be committed to the goal of commercial revitalization. Each must be willing to put forth time and effort into the project and they must realize that plan development and implementation is an important goal in this process.

The purpose of this committee will be to oversee the formulation and implementation of a commercial revitalization plan for Broad Street. This group should meet on a regular basis, monthly if possible. Members of the BSRC should also be willing to hold a series of workshops or distribute a newsletter which would serve as a way of communicating the group's progress and upcoming meetings.

The BSRC should also encourage citizens who are not officially members of the committee to provide input into the formulation of the plan. This will enable the 
committee to more clearly define the needs and values of area businesses and residents in the area.

Initially, this group should determine the exact goals of the commercial revitalization plan for Broad Street. They should then develop a general statement, which is supported by all members of the committee as to the basic goals and assumptions to be used in the commercial revitalization process.

The second step for this committee should be to hire or appoint a manager. Ideally, this person should be the Commercial Coordinator for ENHS. The responsibilities for this position would be to organize all meetings and activities planned by the committee.

The BSRC should also consider dividing into sub committees. While the main goal of the BSRC would be to develop a commercial revitalization plan, these sub-committees could provide valuable input into its formation. The purpose of this strategy would be two fold. First, it would allow group members to develop a specific area of interest related to plan formation. Second, it would encourage the development of several alternatives for the commercial revitalization of Broad Street.

Suggested subcommittees for the BSRC might include:

Business recruitment - This subcommittee would be involved in the investigation of strategies which would encourage new businesses to invest in the Broad Street Commercial District.

Neighborhood recruitment - The responsibilities of this group would be to develop 
involvement of neighborhood residents in the revitalization process.

Clean up coordination - Devising a number of clean up campaigns for the Broad Street Commercial would play an important part in renewing both business and citizen pride in the area. These efforts would provide visible proof of the BSRC's commitment to the development of a Commercial Revitalization Plan.

Marketing Strategies - Members of this subcommittee could research different marketing options which would encourage customers to shop at local businesses. This could include how the entire area is advertised as well as how individual businesses could improve their marketing by changing their window displays and store facades.

By the end of Step One the following should have been accomplished:

1. The formation of a revitalization committee

2. A general statement of the committee's goal

3. The appointment or hiring of a manager

4. Division into sub-committees

After the BSRC has been organized and a general goal statement for the commercial revitalization of Broad Street has been formulated it will be necessary to move on to Step Two. This step involves getting the Broad Street Commercial District designated as a Redevelopment Area. 
Step Two - The Designation of the Broad Street Commercial District as a Redevelopment Area.

At this point in the revitalization process it will be important for the BSRC to include or notify the City of Providence of its intent to develop a commercial revitalization plan for Broad Street. Having the Broad Street Commercial District designated as a redevelopment area will serve two purposes. First, it will enable the BSRC to obtain formal acknowledgement of its efforts to produce a commercial revitalization plan. Second, it will allow the Providence Department of Planning and Development to provide input and assistance for the development of the commercial revitalization plan.

There are a series of requirements which must be fulfilled in order to ensure the designation of the Broad Street Commercial District as a redevelopment area. These requirements are explained in Title 45 , Chapter 32 of the Rhode Island General Laws. (A copy of Chapter 32 is contained in Appendix B.)

This legislation requires that a formal public hearing be organized before the resolution is adopted. For that public hearing members of the BSRC may petition the City Council to designate the Broad Street Commercial District as a redevelopment area.

Included in the petition should be the goal statement of the BSRC which was developed in Step One. Within this petition should also be the request that the 
planning commission assist in the development of the revitalization plan. This will enable the City to provide technical assistance and guidance throughout the plan development process and will also ensure that plan will conform to City guidelines.

The amount of time required to complete Steps One and Two could be from six months to one year depending on the ability to organize the BSRC and having the area formally recognized by the City. After these have been completed it will be necessary to move into Phase Two of the revitalization process.

\section{Phase Two}

This phase is composed of the next two steps necessary in the development of a commercial revitalization plan for Broad Street. These steps are 3) Data Collection and 4) Analysis of Data.

The goal of this phase is to collect all necessary information about the Broad Street Commercial District and its surrounding neighborhoods and to analyze it. It will serve as the basis for the formulation of the revitalization plan itself.

\section{Step Three - Data Collection}

This step involves collecting all available information about Broad Street. It should be noted that some of the information necessary for the completion of this step is contained within this document. Data collected for this step should include: Census Data - As it becomes available the figures for the 1990 U.S. census should 
be obtained. Local ethnic organizations should also be consulted for figures regarding their specific populations within the Broad Street Commercial District area. Historic, Social, and Cultural Information - This information can be obtained from several organizations within the City of Providence.

Inventory of Existing Businesses - A listing of businesses which are currently in place within the Broad Street Commercial District should be collected. Included in this inventory should be the business type, how long the business has been there, whether the building is owned, leased or rented, its location on Broad Street, its facade condition, square footage, and, if possible, the dollar amount of retail business each establishment generates.

Planning Studies - Several revitalization plans and neighborhood studies have been written by the City of Providence. All available documents, including a recent Comprehensive Plan for the City should be obtained.

Funding Sources - This data should include all possible available sources of funding including non-profit and private. Also part of this information should be programs already in place such as the Broad Street Commercial Revolving Loan Program. Inventory of Vacant Lots and Buildings - This inventory should include the building location, total amount square footage, ownership of the building, its potential for use, and its condition including facade and general status.

Inventory of Non-Commercial Units - Included in this listing should be all structures or buildings which are not involved in commercial business but located on Broad 
Street. Information regarding the location of residential, health care, churches and other non-commercial activity should be compiled.

Circulation - This information should include traffic counts for the area which can be obtained from the Department of Transportation. Also included should be a general study of traffic flow into and out of the Broad Street Commercial District. Parking - This would entail obtaining an actual count of the number of available parking spaces within the immediate Broad Street area. This count should include both on and off street facilities.

Customer Survey - This information can be obtained by distributing a questionnaire which will provide a profile of customers who frequent Broad Street businesses, what they buy when they shop there, and whether they live in the local neighborhoods or have come there from another location to buy a specific good.

Merchant Survey - A profile of merchants should be compiled. This survey should include issues and concerns that businesses have which might affect their ability to operate there.

Zoning - A current zoning map and the most recent zoning ordinances can be acquired from the Department of Planning and Development.

Maps - A series of maps should be either obtained or drafted. These maps will help in the definition of Broad Street and the area bordering it. Included should be maps of census tracts, neighborhoods, traffic flow, and open space. 
By collecting all of this information the BSRC will have established an extensive data base from which to work. This step may take as long as three months depending on the ability of the BSRC to collect all of the data mentioned in this step. Having all of the reports, documents and maps available will save time and effort at later points in the process of the plan development.

\section{Step Four - Analyzing Data}

At this point in the process necessary data should have been compiled and reviewed. By evaluating the materials the BSRC will be able to determine issues and concerns which should be addressed in the implementation of the plan itself.

The evaluation can either be done by the entire group or divided into specific tasks. When analyzing the information which has been collected the following issues and trends should be examined:

Census Data - This data should be analyzed to determine trends in the racial and economic base of the neighborhoods surrounding the Broad Street Commercial District. Special attention should be directed toward determining the numbers of Hispanic and Asian populations within these neighborhoods.

Historic Information - When evaluating historic information about the area, a listing of historic landmarks or unique features should be made. This list will aid in the revitalization process by determining focus points for urban design strategies in the Broad Street area. 
Inventory of Existing Businesses - When the BSRC performs an analysis of the existing businesses along Broad Street they should determine what types of businesses are currently operating there as well as what type of businesses are needed. This step will also be helpful in determining future loan recipients for the revolving loan fund. Existing conditions of building facades should also be evaluated to determine specific businesses which might be potential targets for renovation.

Planning Studies - Past planning studies should be evaluated to determine what areas can be improved upon in the formulation of the plan for Broad Street.

Funding Sources - A directory of possible funding sources should be evaluated as to the criteria for obtaining them and who potential recipients would be in the Broad Street Commercial District. A determination should also be made concerning responsibility of obtaining these funds. Should the business owners have a list made available to them or should revitalization funds be coordinated through the BSRC or ENHS?

Inventory of Vacant Lots and Buildings - This inventory should be evaluated in terms of what space is available and its potential for being utilized. Vacant lots should be considered as possible sites for additional parking or small parks which could serve as common gathering areas. Buildings should be examined as future sites for incoming business for Broad Street.

Inventory of Non-Commercial Structures - All residential and other non-commercial structures should be examined. By evaluating the numbers of these structures and 
their location throughout the Broad Street Commercial District the BSRC should be able to determine whether or not this area of concern should be addressed in the plan itself. Because of the high amount of non-commercial uses in the area this part of the evaluation should not be overlooked as it will play an important part in the revitalization of Broad Street.

Circulation - Traffic patterns should be identified for the entire length of the Broad Street Commercial District. Areas of congestion should be analyzed as well as entrance and exit points for the area.

Merchant and Customer Surveys - These survey should be evaluated not only in terms of who shops within the Broad Street Commercial District but also in terms of where they go for other goods and services. By examining the surveys in this manner it will assist in the development of criteria for businesses which should be encouraged for the area. For example; there are no banking services available on the entire length of the Broad Street Commercial District, does this affect the amount and type of shopping done along Broad Street?

Zoning - Zoning for the entire Broad Street Commercial District should be examined to determine if there are any existing code violations or potential areas where the zoning should be changed.

Once these analyses area performed, the BSRC should then develop a statement of issues and concerns which have been determined for the entire Broad 
Street Commercial District. This will section will then be used in the revitalization plan itself.

\section{Phase Three}

Step Five - Development of the revitalization plan

At this stage in the BSRC should formulate its commercial revitalization plan. This document should be made up of the following elements: Goals Statement - This statement should be representative of the goal of the entire project. It should be similar to the original goal of the BSRC.

Description of the Broad Street Commercial District - This section should contain all information about the Broad Street Commercial District and its surrounding neighborhoods. It should include a history of the area, demographic analysis, current inventory of businesses and existing land use for the entire commercial district.

Description of the planning process - The purpose of this section should be to describe how the revitalization plan conforms to City's guidelines regarding redevelopment plans and also its conformance to the Master Plan of the City. Issues and concerns - Contained within this section should be a discussion of findings that resulted during the course of data analysis and meetings. This list of issues and concerns should be divided into subjects such as: existing building conditions, types of businesses which should be encouraged along Broad Street, customer needs, safety issues, and funding concerns. 
Strategies - This portion of the document should, first, focus on developing objectives for addressing issues and concerns for the commercial revitalization of Broad Street. Second, it should develop strategies for the revitalization of the area. This section may include the following:

Division of Broad Street into sections - If a sectional approach is to be considered for the revitalization process it should be presented in this section. A discussion of this approach should include maps showing how the area is to be divided and how the responsibility for these sections will be addressed.

Urban Design Strategies - This should contain a general description of the urban design strategies which have been developed for the entire Broad Street District. Included should be at least one or two of the examples which are going to be contained in the design catalog that is to be distributed to local business owners.

Economic Development Strategies - These strategies should include those which will attract new businesses and retain new businesses. Two of the strategies which should be considered should be:

Expansion of Broad Street Business Association - By encouraging all business owners to become active members of this group revitalization plans will be more likely to succeed. New business owners should be invited to become members as well as those who are already located 
on Broad Street. Membership in this group could also be considered as a requirement for funding.

Marketing Strategies - Suggestions such as the development of a business directory to be distributed by the Chamber of Commerce, the Broad Street Business Association, and other organizations like the BSRC to potential business owners who are looking for a place to locate in Providence. Other ideas which could be discussed might be advertizing strategies, market festival activities, and workshops or consulting services for business owners on how to improve or change their window displays.

Costs of Implementation - A breakdown of anticipated costs and sources of funding should be provided for analysis.

\section{Phase Four}

Step Six - Implementation

At this point the businesses and residents who have participated in the development should be ready to put their plan into action. Before this can happen though, the plan should be presented to the Providence Department of Planning and Development for its suggestions and approval.

Next, the BSRC should develop an action plan which includes a budget and a schedule of activities which are to be divided over a specific period of time. This 
action plan should emphasize the economic development and physical improvement strategies which are included in the plan itself. Steps which should be considered in the action plan are:

Publicize revitalization efforts - By publicizing revitalization activities through newsletters, and the local press, awareness of efforts to improve the business climate along Broad Street will encourage businesses to invest in the area and customers will be encouraged to come and shop.

Prioritize areas within each of the four sections - Originally, those businesses which have the best potential within each of the sections should be targeted for revitalization. By targeting those businesses first, and not the ones that would be the most difficult to revitalize, it should encourage others to join in.

Organize clean up campaigns - The most manageable way to do clean up efforts would be on a section by section basis. Both business owners and local residents should be encouraged to participate. This will also serve as a visible sign that revitalization efforts are being taken seriously.

Organize businesses - All business owners should be invited to become participating members of the Broad Street Business Association and committees within the BSRC. 
Step Seven - Monitoring and Updating of plan

Once the plan has been implemented it should be evaluated and updated on a regular basis. This should be done at first, one year after the plan has been adopted, then every two to five years afterward.

During this process each of the sections of the plan should be evaluated regarding its successful implementation. Strategies or methods which have not proved useful should either be discontinued or updated as necessary. 


\section{REFERENCES}

REFERENCES 


\section{References}

Barringer, Margaret A., and Roche, Peter J. "Neighborhood C o m m e r c i a 1 Revitalization", Economic Development Commentary, vol. 11, no. 1, Spring 1987.

- Strategies for Neighborhood Business Development, Neighborhood Reinvestment Corporation, 1987.

Coppock, J.T., and Sewell, W.R. (eds), Public Participation in Planning, John Wiley and Sons Ltd., 1977.

Garnham, Harry Launce, Maintaining The Spirit of Place - A Process for the Preservation of Town Character, PDA Publishers, 1985.

Gregson, Bob, Show and Sell - A quide to Advertising and Promotions for Small Businesses and Neighborhood Commercial Districts, Neighborhood Reinvestment Corporation, 1987.

Hess, Karl, and Morris, David, Neighborhood Power - The New Localism, Beacon Press, 1977.

Neighborhood Reinvestment Corporation, Commercial and EconomicDevelopment in the NeighborWorks Network 1989.

Providence, Department of Planning and Urban Development,Elmwood Neighborhood Analysis Part I, 1977. Profile, 1977.

- Elmwood Neighborhood Analysis Part II - A Socio-Economic

- Lower South Providence Neighborhood Analysis Part I, 1978.

- Upper South Providence - Proposed Redevelopment Plan, 1984.

- Proposed Zoning Ordinance, October 26, 1990.

- Broad Street Neighborhood Commercial District, June 1978.

. Smith Hill Architectural Workbook, April 1981.

- The Mount Pleasant Business District Revitalization Plan - 1990, September 1990.

. Comprehensive Plan 2000, Camp Dresser and McKee, Draft, 1990. R-1 
Rhode Island Historic Preservation Commission, Elmwood,Statewide Historical Preservation Report P-P-3, June 1979.

Rohe, William M., and Lauren Gates, Planning with Neighborhoods, The University of North Carolina Press, 1985. . South Providence, Statewide Historic Preservation Report P-P-2, September 1978 .

Schwartz, Gail Garfield, Where's Main Street USA?, ENO Foundation for Transportation, 1984.

State of Rhode Island, Rhode Island General Laws, Title 45 Chapter 32. 
APPENDICES

\section{APPENDICES}




\section{FACADE CONDITIONS}

Excellent: The criteria for classifying structures as excellent included; no visible defects on the foundation, exterior shell (paint and structural condition), porches and stairs.

Satisfactory: The criteria for classifying structures as satisfactory included:

1. Foundation: -Occasional missing brick

-Single narrow break or hairline cracks

2. Exterior Shell:

-Some painting required

a) Paint: -Some blistering of paint

-New paint required over architectural ornamentation, window frames, cornice, eaves

b) Structural condition:

-Building in process of painting

-Single or few shingles missing

-Single cracks, slight rot in siding

-Minor rotting of eaves

3. Porches and Stairs:

lattice under porch

-Slight rot in porches/ or damaged

-Needs some minimal repairs

-Stairs painting required

-Complete painting required

Minor Repairs Required: The criteria for classifying structures as "minor repairs required" included:

1. Foundation:

-Large area of deep wear

-Loose, broken and missing bricks

-Multiple narrow breaks

-Small area of general break

-Complete foundation pointing required

2. Exterior Shell:

a) Paint -Total repainting required

-Exterior walls need painting

b) Structural condition:

-Loose holes and breaks

-Small holes and breaks

-Shallow wear or slight rot of structural elements 
3. Porches and Stairs:

-Main rail loose, balusters worn or treads worn with small breaks

-Support of stairs or porches loose

Major Repairs Required: The criteria for classifying structures as "major repairs required" include:

1. Foundation:

-Any of the following defects on over $1 / 4$ of the total foundation:

Large holes

Exterior area of loose structure surface

Wide breaks

Extensive general breaks

2. Exterior Shell:

Bulging walls or wall out of plumb

a) Paint

-Total painting required

b) Structural condition:

-Deep wear or rot of structural elements

-Large holes and breaks in walls

-Bulging walls or walls out of plumb

3. Porches and stairs:

-Deep wear or rot

-Main rail missing

-Balusters broken

-Loose treads with holes

-Large breaks

-Missing or broken supports of stairs or porches

-Loose or sagging elements creating hazardous condition 
IIItary of Boctlon.

mubstituted "as it deems necessary" for "as he drectut neceranaly" in subsection (b); end made Recnuctmenta. The 19BH Hicknactment (P.L 1988, ch. 84, \& 1) oubstituted "the per. (a)

45.31.2.9. Administration. - In order to prevent unnecessary expense and duplication of functions, and to promote uniform and effective adinistration of relocation assistance programs for displaced persons agency may authorize any relocation agency to enter into contracts with any individual, firm, association, or corporation for services in connection with those programs, or may carry out its functions under this chapter through any federal or state agency or instrumentality having an established organization for conducting relocation assistance programs.

Hiptory of Section. punction.

45-31.2-10. Payments not to be considered as income or resources - No payment reccived by a displaced person under this chapter shall be considered as income or resources for the purpose of chapter shall be considered as income or resources for the purpose of determining the eligibility or extent of eligibility of any person for assistance under any state law or for the purposes of determining the eligibility or extent of eligibility of any person for assistance tax law, corporation tax lnw, or other tnx laws. These payments shall not be considered as income or resources of any recipient of public assistance and the payments shall not be deducted from the mecipient would otherwise be entitled.

ilistory of section. paymencs" for "Such paymencs" at the begin

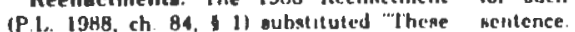

45-31.2-11. Appeal procedure. - Any person or business concern aggrieved by final adninistrative determination, concerning cligibility for relocation payments authorized by this chapter may appeal the determination to the superior court in the county in which the land taken for public use is located pursuant to the provisions of chapter 35 of title 12 .

\section{CHAPTER 32}

\section{REDEVELOPMENT PROJECTS}

\begin{tabular}{|c|c|c|c|}
\hline $\begin{array}{l}\text { SECTION. } \\
\text { 35.32-1. }\end{array}$ & $\begin{array}{l}\text { Compliance prerequisite to fur- } \\
\text { ther priscedings. }\end{array}$ & SEC.TION. & $\begin{array}{l}\text { Resulution of necessity for ac- } \\
\text { quisition. }\end{array}$ \\
\hline $\begin{array}{l}45-32-2 \\
45-32-3\end{array}$ & $\begin{array}{l}\text { Plannilig commission required. } \\
\text { Ciencral community plan - }\end{array}$ & 45.32.27. & $\begin{array}{l}\text { riling of resolution, plah, and } \\
\text { deciaration. }\end{array}$ \\
\hline 45-32-4. & $\begin{array}{l}\text { Minimum requirements. } \\
\text { Resulution or ordinance desi }\end{array}$ & 4i. $32-28$. & $\begin{array}{l}\text { 1)eposit of compensation of prop- } \\
\text { erty taken. }\end{array}$ \\
\hline & $\begin{array}{l}\text { nating redevelopment orea - } \\
\text { Public hearing. }\end{array}$ & $\begin{array}{l}45-32-29 . \\
45-32-30\end{array}$ & $\begin{array}{l}\text { Addition to or return of deposit. } \\
\text { Vesting of title to property }\end{array}$ \\
\hline 45-32. & rs of agencies. & & \\
\hline 45-32- & $\begin{array}{l}\text { Selection of project areas - For- } \\
\text { mulation of redevelopment } \\
\text { plans. }\end{array}$ & 45-32-31. & $\begin{array}{l}\text { on of resolution } \\
\text { tion. }\end{array}$ \\
\hline 45-32-7. & $\begin{array}{l}\text { Submission of redevelopment } \\
\text { plans - Conformity to master } \\
\text { plun. }\end{array}$ & $\begin{array}{l}45.32 .33 \\
45.32 .34 \\
45.12 .35\end{array}$ & $\begin{array}{l}\text { reed price. } \\
\text { on damageas. } \\
\text { of infants ar }\end{array}$ \\
\hline 45-32-8. & Conlents of redevelopment plan. & & \\
\hline 45-32 & ures of redevelop- & 45-32-36. & \\
\hline $\begin{array}{l}45-32.10 . \\
45-32-11 .\end{array}$ & $\begin{array}{l}\text { Petition for zaning changes. } \\
\text { Notice of hearing on plan. }\end{array}$ & & $\begin{array}{l}\text { sation - Expediting proce } \\
\text { ings. }\end{array}$ \\
\hline & Condu & & Ordera as to charges on lar \\
\hline & & & \\
\hline 45.32 & for expenditure of & 45-32 & $\begin{array}{l}\text { Tuxation of real property } \\
\text { quired. }\end{array}$ \\
\hline 45-32-15. & on of incent to change & & $\begin{array}{l}\text { Prorati } \\
\text { Cooper: }\end{array}$ \\
\hline 45-32-1 & iment for prop- & & $\begin{array}{l}\text { Frrmalities in letting of con } \\
\text { trncts. }\end{array}$ \\
\hline 32.1 & $\begin{array}{l}\text { Findin } \\
\text { Pring }\end{array}$ & 45-32 & Compl \\
\hline & 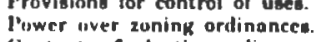 & 45.32.45. & \\
\hline & & & \\
\hline & $\begin{array}{l}\text { Responsibility for carrying out } \\
\text { plan. }\end{array}$ & 45.32-4 & $\begin{array}{l}\text { Consent to inclusion of area } \\
\text { project of contiguous city. }\end{array}$ \\
\hline 45.32.2 & $\begin{array}{l}\text { Further proceedings as to rede- } \\
\text { velopment-Actions to con- } \\
\text { lest validity. }\end{array}$ & & projecte \\
\hline $\begin{array}{l}45.32 \cdot 23 \\
45.32 .24 \\
45.32 \cdot 25\end{array}$ & $\begin{array}{l}\text { Modificalion of plan. } \\
\text { Power of eminent domain. } \\
\text { Property devated to other public } \\
\text { usc. }\end{array}$ & 45.32-49. & Gusrentee of community. \\
\hline
\end{tabular}

45-32-1. Compliance prerequisite to further proceedings. A community must comply with the requirements of $\$$ 45-32.2 to 45-32-4, inclusive, before proceeding further under chapters 31 to 33 , inclusive, of this title.

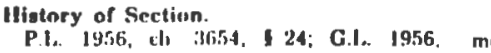
15.32-1 Comparalive Iegislation. Redevelop Croms

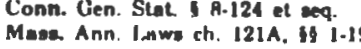


1. Ilemir Bulle Brower. Conkl., nimend $X X V I I I$. Is 4 (ace now R.I.

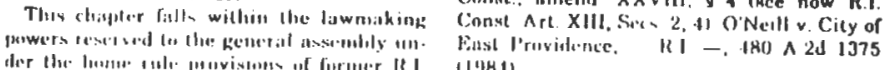

45-32-2. Planning commission required. - The community must have a planning commission.

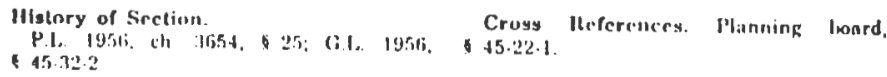

NETES MO BI:CISHONS

1. Tinking lbased on Priwate Firm's Eval. untion.

consulting firmis evaluation that this would finted to create in phanning cum. slitule a proper puldic use allluwing for con

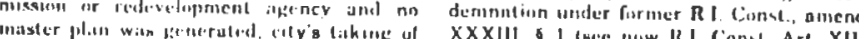

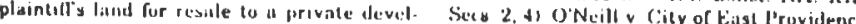

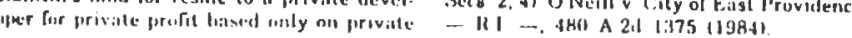

45-32-3. General community plan - Minimum requirements. - The comumunity must have a master or general community plan adupted by the phanning commission or hody, and in ewther cuse the plin must include at loast he followive

(a) A land use plan which dosichutes the at least the following:

(a) $A$ land bution and general location and extent of the uses of the land for housing, business, imlustry, recreation, education, public building and grounds, and other categories of public and private uses of land. (b) The general location and extent of existing and proposed major thoroughfares.

(c) A statement of the standards of population density and build. ing intensity recommended in and for the various districts and other territorial units, together with estimates of ruture population growth, in the lerritery covered hy the plan, all correlated with the land use plan.

(d) A description of the area or areas in which blighted and substandard conditions are found and recommendations as to the area of areas which should be designaled for redevelopment.

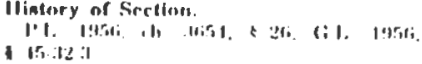

1. Tnking Ansed an P'rivate Firni' Evanl. consulting firm's evnluation that this would . Nlictuall revilatization of area did not con

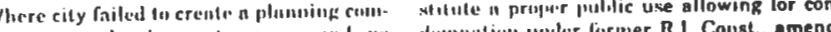

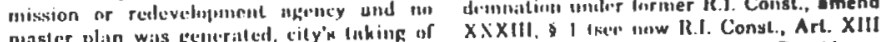

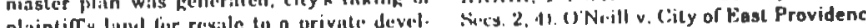

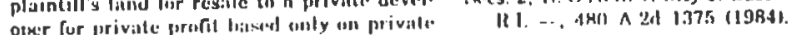

45-32-4. Resolution or ordinnnce designating redevelopment area - Pullic hearing. - The legislative body of the comment area - Pullic hearing. - The legislative body of the communily must have designiled hy resshlintion or mive bodyce one or more areas within the conmunity as a redevelopment area or areas. (Whenever the word "resolution" is hereinater used, il shall be deemed to incan "resolution or orilinance." liach such resolution shall include a descriplion of the boundarics of the area or areas designated as a redevelopment arca. Bcfore passing such a resolution, the legislative body or the cominittee thereof to which the proposed resolution has been referred shall give notice of the date, time, posed and purpose of a public hearing or hearings with reference place, and the planning commission there al in accill be developed in accorlance will the considered. The nolice shall be publis the hearing in a newspaper of for three (3) successive sueks priction general circulation published in the communily, or if now suewspaper is published in the community, then in an circulation in the community. Al the public henring all persons or agencies interested shall have an opportumily to be heard and to submit communications in writing. The putilic hearing required by this section may be held jointly with the hearing upon a redevelopment plan for a project area as provided in $\$ 45-32-11$ if the legislative body 80 directs. Any person, group, association, or corporation may in writing pelition the legislative body to designate one or more areas within the conmmunity as redevelopment areas, and may submil with their petition plans showing the proposed redevelopment of those areas or any part or parts thereur.

itlotury of Section.

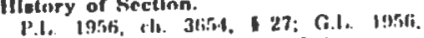

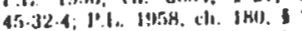

(1)

(P.). IIIHA, cli. H.S, I 11 made cevoral substi-

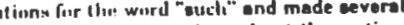

\section{natros To ingersions}

1. Notlce.

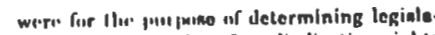

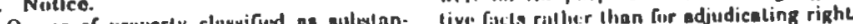

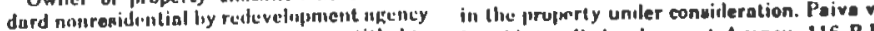

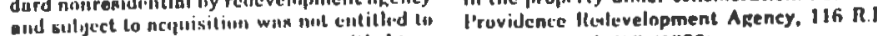

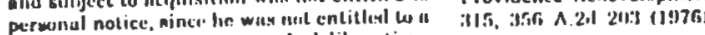


15.82-5. (imponate powers of aneneies. - Piach mevelop-

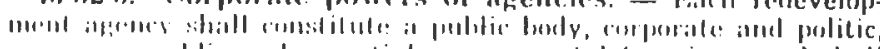

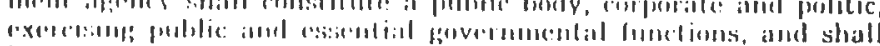
have all ilne puwers necessiny and conventent to carry out and effec-

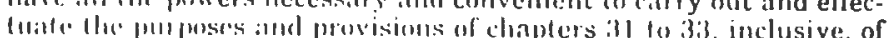

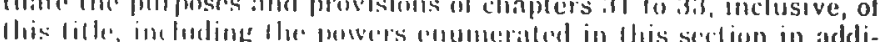

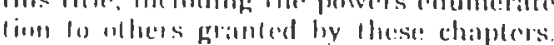

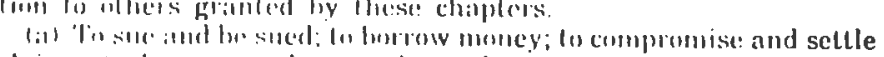
diains: to have a seal: lo mike and execute contracts and other

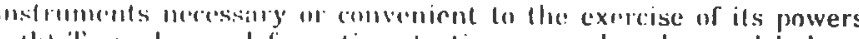

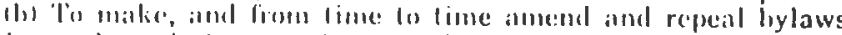
rules, and regulatims consistant with chapters :31 ta 333, inclusive, of this lille lo arry into elferd the powers and purposes hereof. (c) To sedect and appoint such oflicers, inenls, counsel, and em-

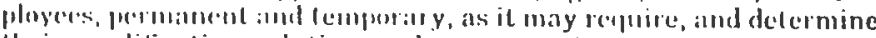

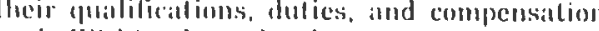

(d) Willun llue redevelopment areat or lorr purposes of' redevelop-

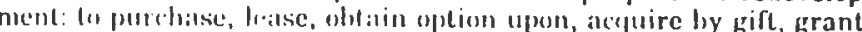
beylest, devise, of ofleterwise, any real or persombl properly, or any estite al inlerest therein, tonether with any improvements thereon to actuitre by lhe exercise of the powver of eminent domain any real property or any ustate on inlerest therein although temporarily not precuirud an achieve the purpuses of chapters 31 lo 33 inclusive,

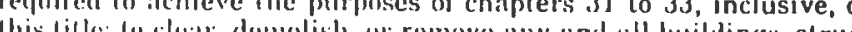

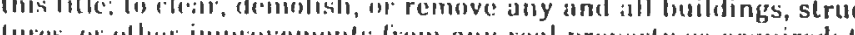
lor..., renthit

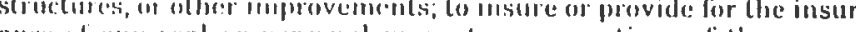

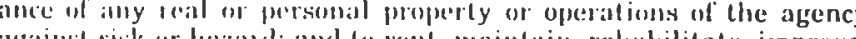

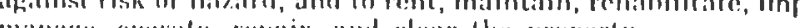

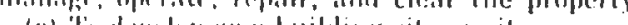

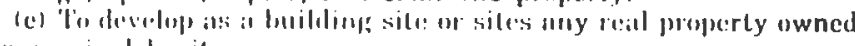
ar alcunisced by it

(1) 'lo callsis: strerls and highways to be laid out and graded, and pasements or blher road surliceing, sideswalks, and curbs, public utilitic's of every kimd, pioks, playsrounds, and oflucr recrealional areas,

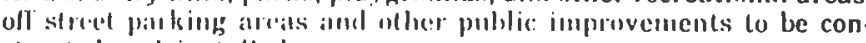
structed and installond

(16) To prepare or have prepared all plans necessary for the redevelopment of bighted and sulditandard alreas; wilh the consent and

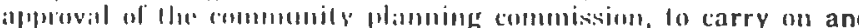

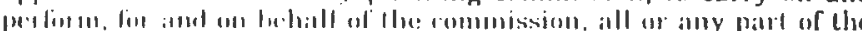

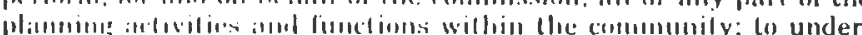

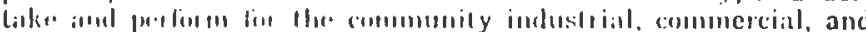

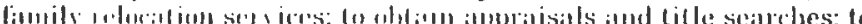

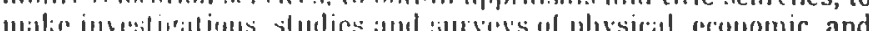

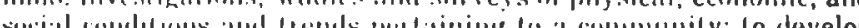

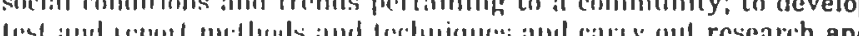

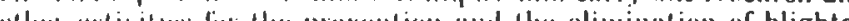

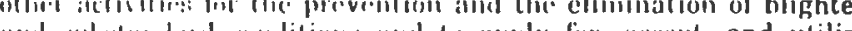

grants of fiunds from the federal foveriment and other sources for finose purposes; 10 enler upon any huilding or property in any redevelemment areat in order lo matke investigations. studies and surveys, and, in the event entry is denied or resisled, an ngency may petition the order for this purpose. Upon the liling of such a petition, due notice thereof shall he served on the persen denying ar resisting entry, and after hearing thercon, the court silall enler all order granting or denying the petition.

(h) To undertake lechnical assistance In property owners and other privale persons to encourage, implement., and facilitate voluntary improvement of real properly.

tha) 'foundertake and calry oul code enfircenent projects pursunut to the provisions of appropriate federal legislation.

(i) 'l'o invest any funds held in reserves or sinking funds or any funds nol required fior imnediate disbursement, in property or securilies in which savings banks may legally invest funds subject to their control; In purchase its honds at n price not more than the primeal aunount thereol and accrued interest, all bonds so purchased to be cancelled.

(j) 'To sell, lease, exchange, suldivide, transfer, assign, pledge, encumber (by morlgage, deed of Lrust, or otherwise), or otherwise dispose of any real or persunal properly or any estate or interest dispose of any real or persunal property or any estate or interest of lhis title, to the United States, lie stille gevernment, any state public body, or any privnte corporation. firm or individual at its fair value for uses in nccordance with the redevelopment plan, irrespecvalue for lises in necordance will the redevelwhent plan, imrespeclive of the cost of acquiring and prepnring the property for redevelopment. In determining the fair value if the property for uses in accordance with the redevelopment plin the agency shall take into account and give consideration lo the lises and parposes required by the plan, the restrictions upon, and the oligigations assumed by the purchiaser or lessec of hie property and the ohjectives of the redevelopnent plan for the prevention of the recurrence of blighted and substindard conditions. Any lease or sale of the property may be made without pubsic birdding provided, however, that no sale or lease shall be nitde until al least len (10) days nfter the legislative body of the comminnily hins received from the ngency a report concerning the proposed sale or Jease.

(k) 'lo alligile the purchanser or lessece of any real or personal property or any ablate or inlerest therein: 111 to use the property only lor the purpose and in the miuner stated in the redevelopment plan: (2) to begin nnd complete the construction or rehabilitation of plan. any : che fixces as reasonable and (i3) to comply will sucls other condilions us in the opinion of the ayency are lions as in the repine

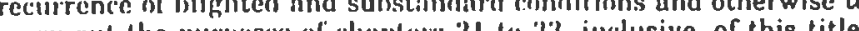

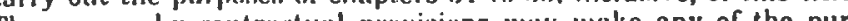


chassers' or lesseres' obligations, covenants, or condilions running with the land, and may provide that upon hreach thereof the fee shall revert to the antency.

(1) 'To exercise all or any part or combination of the powers herein granted.

Nothing herein conlained shall authorize an agency to construct nny new buildings for residential, commercial, industrial, or olher uses contemplated by llie redevelopment plan.

Nothing herein conlained shall authorize an agency to retain for a period in excess of five (5) years from the date of acquisition or within such other additional period of time as the legislative hody fixes ats reasonialile, the foe or any cstate or interest therein to any building, strueture, or wher improvement, not demolished or otherwise removed, which has been acquired by the agency in accordance with the redevelopment. plan.

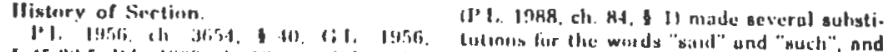

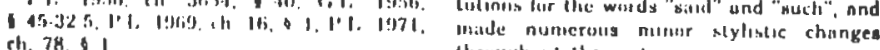
throuphente the sctum

NOTES TO DECISIONS

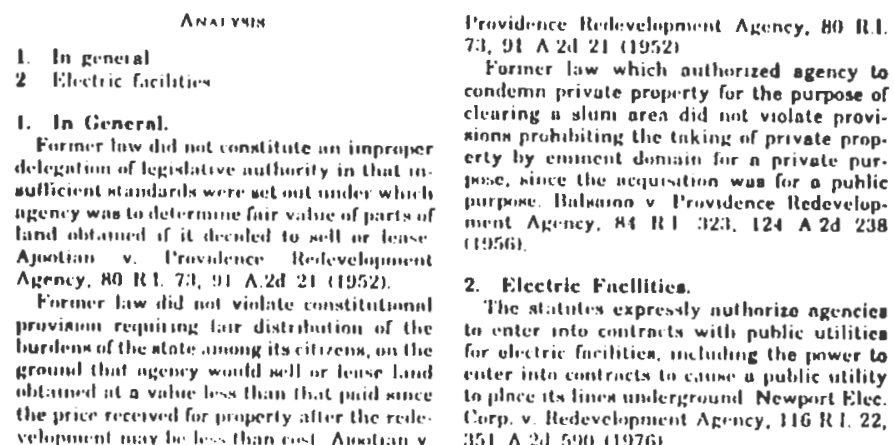

45-32-6. Selection of project nreas - Formulation of redevelopment plans. - l'he redevelopment agency may of its own motien, or shall at the direction of the legislative body, select one or Inore project atrias conprising all or a portion of a redevelopment urea, ansi formulate: a indevelopment plan for each project area. Redevelopinent plins inay le prepared ly the planning cornmission in the event the members of the ngency have not been appointed or at the request of the agency.

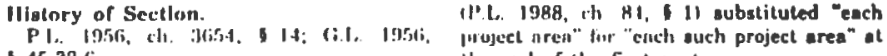
$14.5-32$ fi.

NoTHS gu BHCLSUNS

1. 'Tuking Isusted on I'rivute Firm's livisl. consulting firm's pvaluation that this would cillecluille revitalization of area did not con-

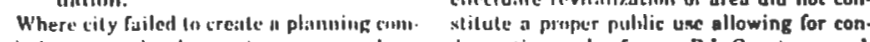

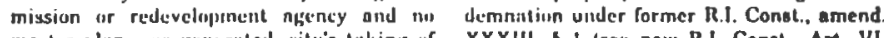

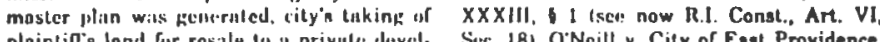

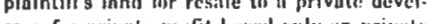

R1. -180 A 211375 (1984)

45-32-7. Submission of redevelopment plans - Conformity to master plan. - AIl redevelopment plans shall be submitted to the legislative body by the redevelopment agency. Every redevelopment plan shall conform to the master or general community plan insofar as the litler applies to the redevelnpment area. The agency shall consult with the planming commission of the community in formulating redevelopment plans liefore their submission to the legislative body. Whenever a redevelopment plan is submitted to the legislative body, copy thereof shall be submitted to the planning commission which shall report to the legislative body within thirty or general plan of the community.

Hlatory of Section. 145.32 .7

Notres To m:Casmos

Amatress

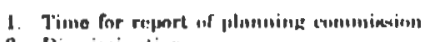

2. Discriminsblien

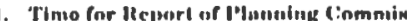

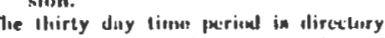

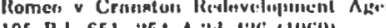

2. Discrimination.

45-32-8. Contents of relcvelopment plun. - The redevelopment plan shall include, without limilation, the following:

(a) A description of the houndaries nnd location of the project area:

(b) A description of the existing blighted nnd substandard conditions in the project area;

(c) A plan describing proposed land uses in the project area:

(d) Proposed standards of population densities, land coverage, and 
(e) $\wedge$ description of proposed at inges in strects and utilities: (f) A description of proposed chan gees in zoning or cxeceptions, variincess. or moliticaltions thereto

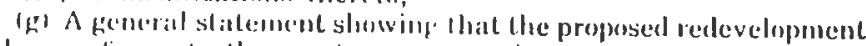
plan conlorms to the master or finneral community plan;

(h) $A$ stalement showing the litids in the project area to be acfuired and buildings or structure: to he demolished and removed;

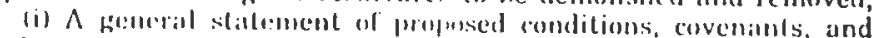

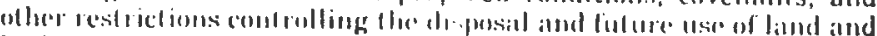
houldings in the projest area

(j) 1 general stalement of the extent of relocation resulting from the propeses redevelopment al llow ale:a and the proposed method for rohousing of displacerd persons:

(k) A stillement of llae estimilded cost of carrying out the redevel. opment plant, ind a descriplion of the metherl of linauciug the pro-

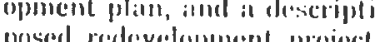

1/) $\wedge$ generill statemenl showing how the purposes of chaplers 31 [1 3:3, inclusive. of this tille would be allained by redevelopinent.

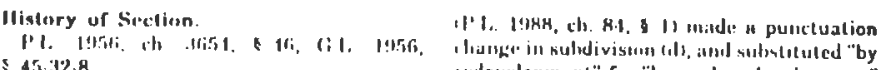
redevelopinent" for "liy surth iedevelopnicont"

15-32-9. Optional fentures of redovelopment plans. $-\Lambda$ redevelepment plan maty. willumit limitation, provide for the following:

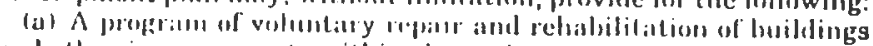
and ollser innerevements within lhe project atrea in accordance with the redevelopment plan; snd/or

(b) Acruisition of single or sciltered parcels of real property within the proiect areal and demolitim or removall of buildings or improvements therenn where necessaty to eliminate unhealthrul, insanitary, or unsafe conditions, lessen density, reduce traffic haz-

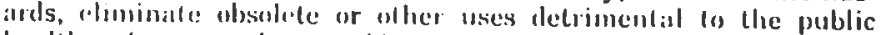

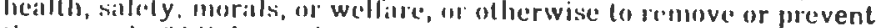

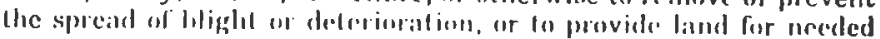
community lan dities.

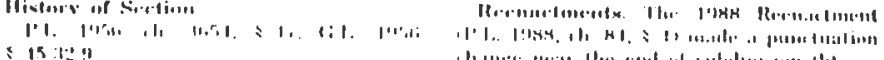

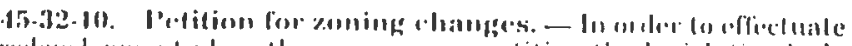

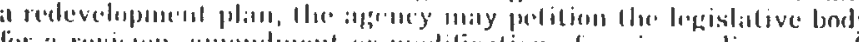

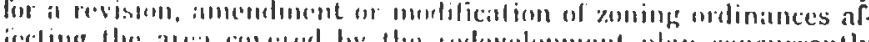

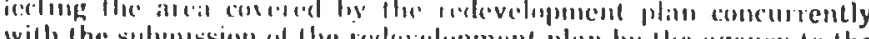
with the sime

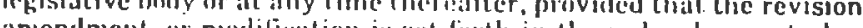
aniendatent noditiration is set forth in the redevelopment plan. tim with the hearing on the redevelupment plan required by 45-32-11; provided, however, that the provisions of $\$ \$ 45-24-4$ and 15-21-5 slonll he applicable to the pertition.

Ilistury of Sicction.

I. I. I9:. I9: (15.).32.10.

1il: (i.). Imsiti,

"such" throughout the

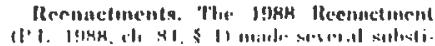

Cirusg Rerfurences. Zuning ordinnnes,

45-32-11. Nolice of hearing on plan. - Upen submission to the legislittive bodly of n redevelonment plan the lerislntive body or the comuitte thereof to which the plan has luen referred shall set cime lix a pace lio a or the plan. The time or hering shater receipt hy the legislative buty of the redevedepment plan from the agency. Notice of the heuring shall be given by publication in a newspaper in the same manner nud to the same extent as provided for pulsication of notice in $\$ 45-i 32-4$.

Histury of Sicetitun.

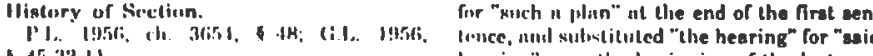

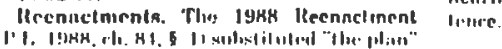

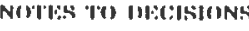

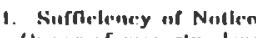

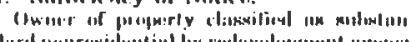

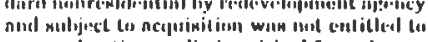

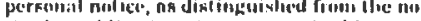

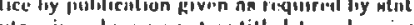

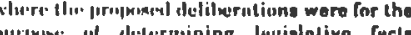

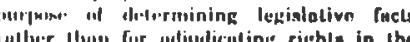

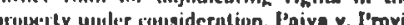

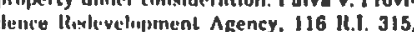
:

45-\$2-12. Conduct of henring. - N1. the hearing the legislative bosly ur the commillee therent to which the plian has been referred shall comsider the plan and repert., if uny, of the planning commis sion, and mny recommemelations the agency may make, and shal take such other evidence and lestininony ns mily be presented conrerning the mallers under considerntiun.

llistury of sientiten.

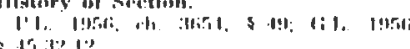

15-12-1:1. Adtoption of plan. - If the legislutive body deter-

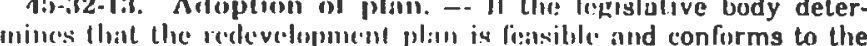

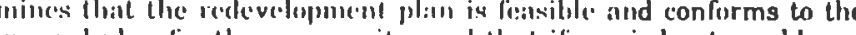

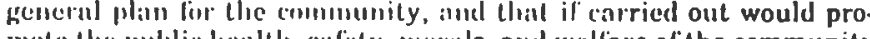
mole the public hinhth, siftely, manls, and wellare of the community and would effectunte the purposes of chapters 31 to 33 , inclusive, of

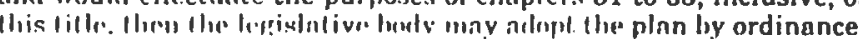


45-32-14. P'rovision for expenditure of money. - If the plan provides liu the expenditure of any money by the community, the egislative body shall provide for the expenditure at the time or in cunnection witl, the approval of the plan, provided, however, that nothing herein contained shall enlarge the power of a town council to make an appropriation which his not heen approved by a finan. cial town niceling.

llistery uf sinection

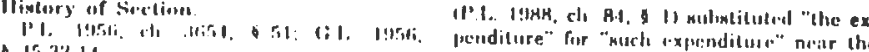

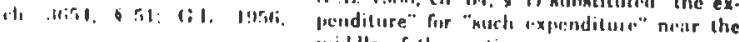

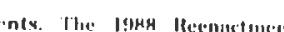

45.32-15. Declaration of intent to change strects. - If the plan provides for the opening, closing, widening, or changing the grade of existing streets or alleys or any other modification of the existing street layout in the project area, the legislative body shall declare its intention lo institute proceedings therefor at the time or in connection with the adoption of the plan.

Ilistory uf Serction

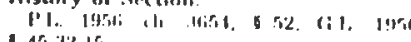

45-32-16. Provision for payment for property condemned. - Ir the plan grovidess for the contcmination of any real property the legislative body sholl not adopt the plan unless it contains adequate provisions for payment for property so acquired as provided by law.

llistory of Section.

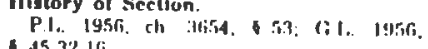

45-32-17. Iincling as to federal aid. - Ir the plan provides for financial aid froin the federal goverment, that provision of the plan shall not be approved by the legislative body unless it finds that the linancial and lom the federal gevermment provided for in the plan is necessary to entable the land in the project area to be redeveloped in accordance wills the redevelumment plan.

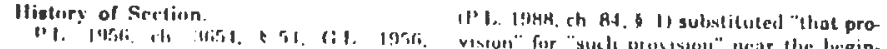

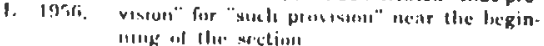

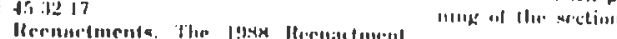

45-32-18. Provisions for control of uses. - No plan shall be approved unless it provides for the retention of controls and the establishment of any restrictions or covenants which may run with the real property sold, leased, or otherwise disposed of for private or public use for such periods of time and under such conditions as in the judgment of the legislative boly are necessary to effectuate the purposes of chapters 31 to 33 , inclusive, of this title.

History of Section. 1. P. 19.16 . 32.18 .

Itrenatet ments. The 1988 Reenactment (1)

45-32-19. Power over zoning ordinances. - Notwithstanding the provisions of any other statule to the contrary, the legislative body shall have power by ordinance to revise, amend, and modify zoning ordinances nflecting the area covered in a redevelopment plan in accordance with \& $\$ 5-32-10$.

Histary of Sectlion. 1. 45:12.19.

Her nuctmenints. The 1988 Reenactment

45-32-20. Contents of adoptive ordinance. - The adoption of a redevelopment plan by a legislative body shall be by ordinance. The ordinance shall:

(a) Desigmate the project by aren, nanne, and number.

(b) Include findings that the project area is blighted and substandard and requires clearance, replanning, reclevelopment, rehabilitainn, or improvernent or any combinntion lliereof.

(c) Set forth the purposes nud intent of Ihe legisintive body with respect to the project nrea.

(d) Refer specifically to the determinations required in $\$$ 15-32-13 to 45-32-18, inclusive.

(e) Incorporate by reference the redevelopment plan.

(I) Designate the approved plan ns the oflicial redevelopment plan for the project area.

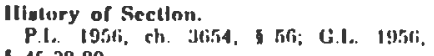

nance" fur "Such ordinn nce" at the heginning

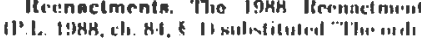

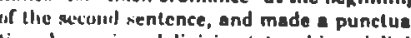
and in subdivi-

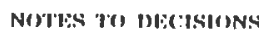

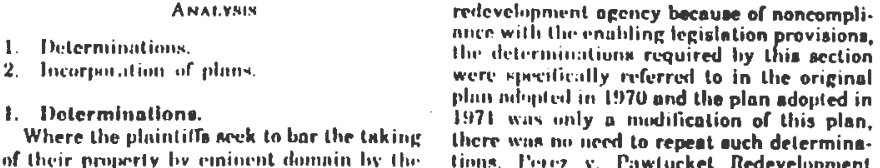




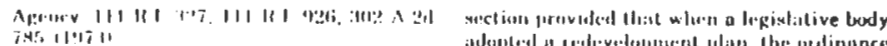

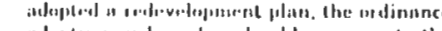

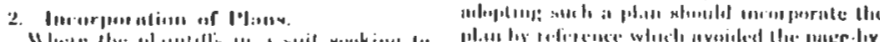

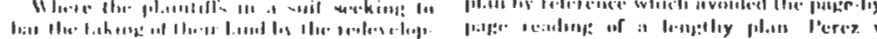

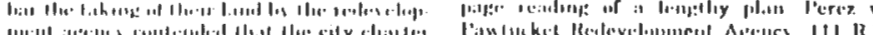

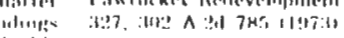

15-32.21. Mresponsilvility for carreing out plan - Alter enactenent of the ardinance described in $15.32-20$, the responsibility

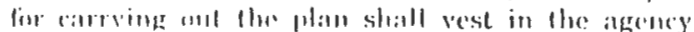

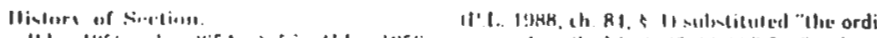

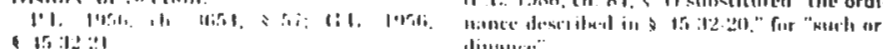

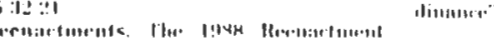

\section{NOTHS II MICISHNS}

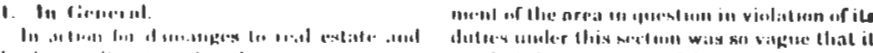

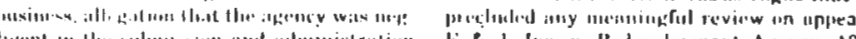

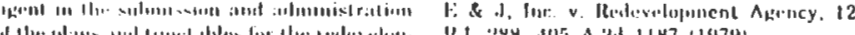

45-32.22. Virtluer procerelings an 10 redevelopment - Ac-

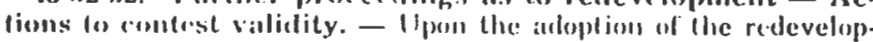

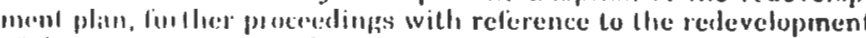
of lle project area may be commeneced immedialely hy the agency. Actions lo contest llac vallidily of the proceedings prescribed by $\$ \$ 45-32-11$ 10 $45-32-21$, inclusive, must be commenced within thirty $30)$ diass afler the actoption of llie redevelopment plan, and no action therealter commeneed shall raise any question concerning the valid. ity of the proceredings and the adoption of the redevelopinent plan provided for in the forregoing provisions of this chapter and chapter 31 nf this tille. After the expirat ion of that period of thirty (30) days. the validity of the proceedings and the adoption of the redevelopment plaus shatl be conclusively presumed Any potition to shy the

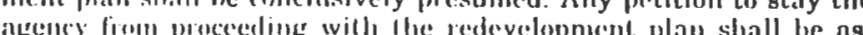

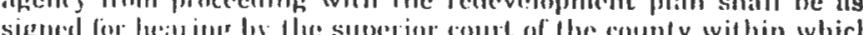

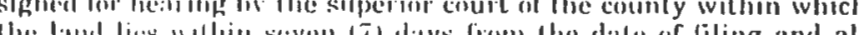

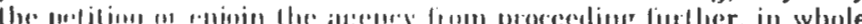

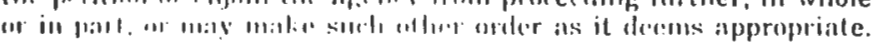

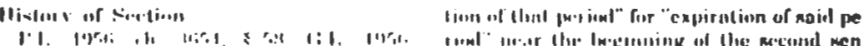

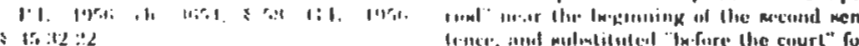

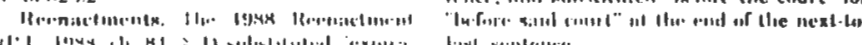

NOTIS TW MECISIINS

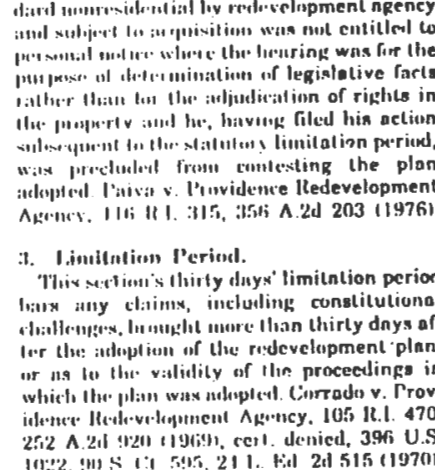
III.2.

45-32.21. Modification or plau - Upon lle recnmmendation of the agency, a redevelopment plan may he modilied at any time by the agency, n redevelopment planimative lmoly at its own discretion.

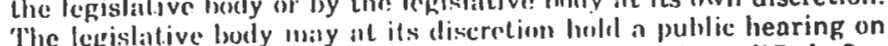

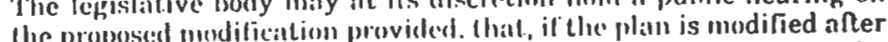

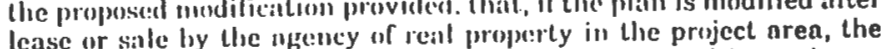
modification hy the ngemey of reat property in the project nrea, an the lessec or purchaser, or his or her successor or suecessors or assigns in interest, miny he enlitled to nsisert.

lllatury of Sacellun.

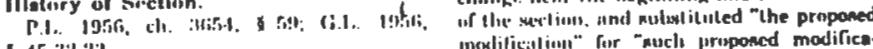

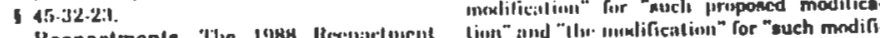
(IV)

45-32-21. Power of eminent domain. - Notwithstanding the

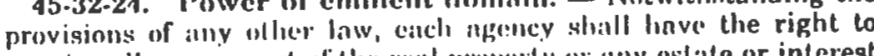

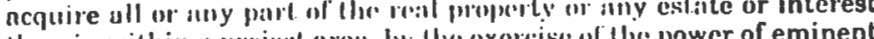

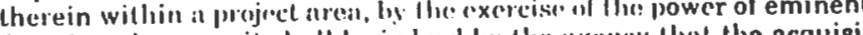

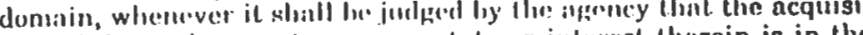

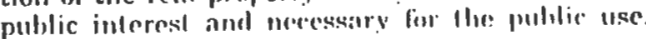

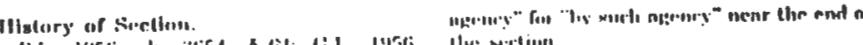

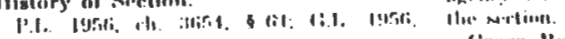

1 45.32.2.

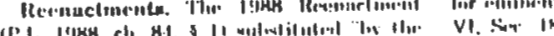


NOTES TO DECISIONS

1. In Lienerming

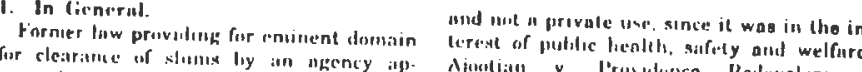

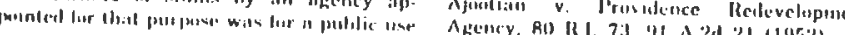

45-32-25. Property devoled to other public use. - If any of the real property, estite or interest therein, inclused - If any of project area is devoted to a public use it may nevertheless be the quired, and the taking shall be effective provided that no real be acerty or estate or interest thercin belonging to a cily or no real propstate governmon to the real property or estate or intuled without its consent, and that no real property or estale or interest therein belonging to a public utility may lee actuired without the approval of the division of public utilities or other officer or tribunal having regulatory power over the utility. Any real property or estiste, or interest therein already owned or acquired by the agency may nevertheless be included willin the aching for the purpose of actuaring any outstanding interest in the real property.

Hligenry of Sertion.

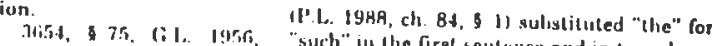
Iteenactm in the nectomit netrener

45-32-213. Resolution of necessity for ncquisition. - The necessity for such acquisition shill be conclusively presumed upon the adoption by the agency of a resolution which shall:

(a) Contain al description of the real property or any estate or interest therein suflicient in detail to permit an identification

(b) Declare that the acquisition of the real property or any estate or interest therein is in the public interest and nucesary for the public use.

(c) State that the real property or any estate or interest therein is included in a redevelopment project approved under this chapter.

llistory of Siction

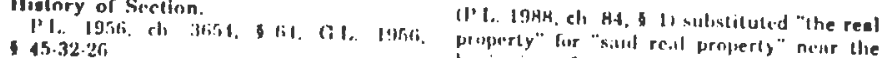
2.5.32-26i

45-32-27. Filing of resolution, plat, and declaration. Within six $(6)$ montles after the adoption of a resolution pursuant to $\$ 45-32-26$, the agency shall cause to be filed in the land evidence records of the city or luwn where the real property is located:

(a) A copy of the aforesaid resolution.

(b) A plat showing the real property taken or affected. the real property or estate, or interest therein, is taken r.ursuant to

the provisions of chapters 31 to 33 , inclusive, of this title and indicating the nature and extent of the estate or interest in the real property taken as aforesaid.

Ifistory of Section.

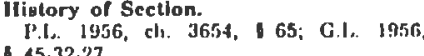
4. $45 \cdot 32 \cdot 27$.

15-32-26" fur "montha therea Rer" near the

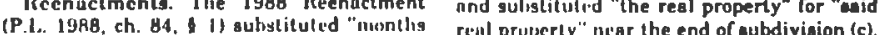
P.l. 19R8, ch.

45-32-28. Deposit of compensation of property taken. Upon the filing of the copy of the resolution, plat, and declaration, as described in $\$ 45-32-27$, the agency shall file in the superior court in described in $\$ 45-32-27$, the agency shall file in the superior court in
and for the county in which the real property lies a statement of the and for the county in which the real property lies a statement of the sum of money estimated by the agency to be just compensation for the property taken, and shall deposit in the superior court to the use of the persons entitled thereto the sum set forth in the statement or a greater or lesser sum in accordance with an order by the court deterclaims of all persons having an estate or interest in the real property.

IItistory of Srctinn. 1 15.32.28. Mocnactmente. Tho 1988 Roonnetment "the" for the worda "uaid" and "euch"

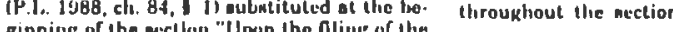

45-32-29. Addition to or return of deposits. - Whenever, from time to time, the agency has satisfied the court that the amount from time to time, the agency has satisfied the court that the amount deposited with the court is either greater than required or is insufficient to satisfy the claims of all persons interested in the real property, the court may order that the amount of the excess shall be repaid to the agency or may order additional sums deposited as the court deems necessary. Whenever the agency has satisfied the court that the claims of all persons interested in the real property taken have been satisfied, the unexpended balance shall be repaid forthwith to the agency.

lliwtory of Siction

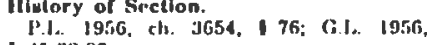
145.32 .29 . 1998 Reelinctment change near the Ireginning of the sectiun: ulistitutud "llue rent property" for "maid real properly" nnd "the excese" for "sny auch ex cens" wean lie middle of the rection; and sub- 
45-32-30. Vesting of title to property taken. - Upon the filing of the copy of the resolution, plat, and declaration in the land evidence records of the city or town and upon the inaking of deposit in accordince with the order of the superior court, title to the real property in lie simple absolute or the lesser estate or interes therein is is specified in the declaration, shall vest in the agent and the real property shall be deemed to be condemned and agency, the use of the argency, and the right to just compen vest in the porsens entitled thereto.

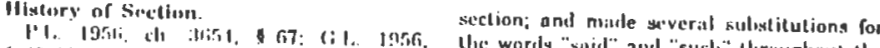

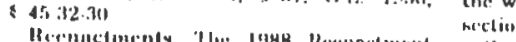

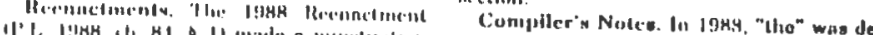

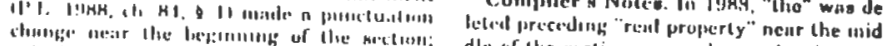

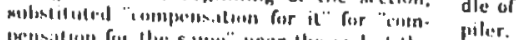

45-32-31. Publication of resolution and declaration. - Afer the filing of the resolution, plat, and declaration, pursuant \$5.32-27, the secretary of the agency shall cause a copy of the resolution and declaration lo be published in some newspaper published in the county where the real property lies, at lower pubweek for tliree inl succosive weal property lies, al least once a

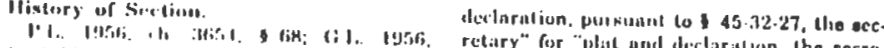

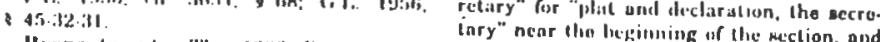

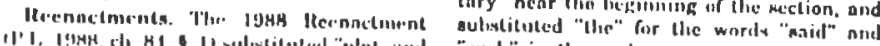

45-32-32. Service of notice of tnking. - No sum so paid into the court or any interest paid thereon shall be charect so paid into fees of any nature. After llie filing of the copy of the resolution clerk's and declatation, mitice of the taking shall te served upon the owners of or persens having any estate or interest in the real property by the sheriff or the sheriff's depulies of the county in which the person or persons reside, hy leaving in copy atlested by the secrelary of the angency of the resolution and declaration with each of the persons personally, "r at lloeir Iast and usual place of alode in this state with some lerson living there, alld ill case the person or persons shall not

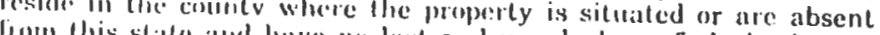

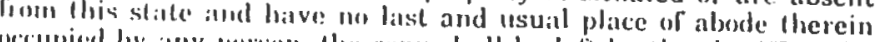

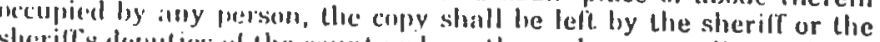
sherife depties al the county where the real property lies with the mrsum, if any. In charge of or having pussession of the real property if the sime is kllwwII lo the nificer. Whenever any owner or person "nllited to any estitte in an any interest in any part of the real

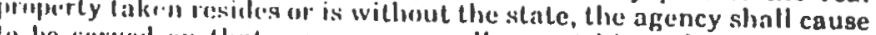

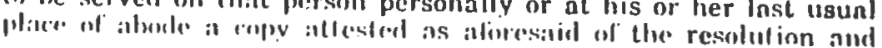

(1) which person shall make declaration by any disintere of and of the mole in which, the time affidavit of the service therl the service lisis been made; or service within, and the place at which, lhe sern such service by the person thereof may be male by the ndimission of on the back of a copy of the resolution her acknowledgment thercollefore an acknowledged.

chnnger neitr llwe leginning of the mecond sen-

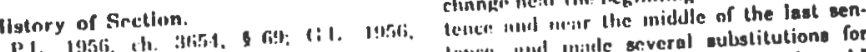
(45i-32-32.

(1) lence." num in:unle several mulstitutiona ror Mr.

. If any person ghall 45-32-33. Payment of ngreed price. - If any peraterty, or estate or agree wilh the stgency for the prien of nuntication of all parties in interest thercin so taken, the coml, an whou be paid forthwith from interest may order that the sum agreed upin to be awarded in the

the money deposited, as the just conmenist in $\$ 45-31-19$.

proceedings, except ns otherwise provile in spo-

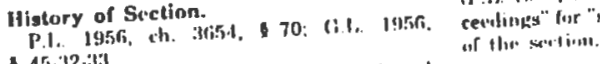
1. 45. $12 \cdot 33$. 33 . uf the suritint.

Ther of 45-32-34. Trial by court on dnmage. sons entilled to any entalce of the real erty, and who can or inlerest therein, sol liken, may, within three property, or estate or in the lisking. "Ir, if he or she has no notice, (3) months nfter notice from the first mulitication of the copy of the may within one year fion refierred to in this cliapter, apply by petiresolution nnd dis cour in and for county in which the real tion to the superior forth the Laking of his or her real property or property les, setting tor and praying for ill assessment of damages. estale or interest the the court shinll cause twenty (20) days Upon filing of the peting wo to be given to the agency by serving a notice of the pentency the with a certified copy thereof, and resident attorney of the me the thinl thereol. Petitions brought

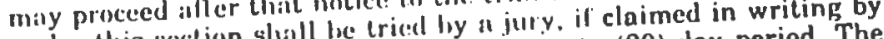
under this section the anderiod. The

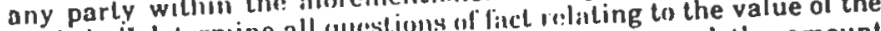
trial shall detornine all westere interest therein and the amount real properly and any ex judgment in the proceeding, execution thereof. Upon the entry in jidsoy so clepusiled in court and in deghall he issucd agminst the monch of the agency. In case two

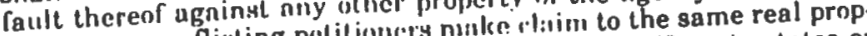
(2) or more conting

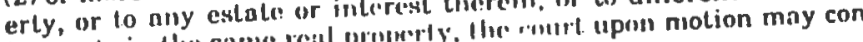


solidate their several petitions for trial at the same time and may frume all necesiary issiles for the trial therenf. All proceedings I ake pursuamt lo the provisions of this chitpter shall lake precedence ove all civit milfers penting brefore the court, or if the superior court in ant for the counly in which the real property lies be not in session in the comnly, then the same may be heird in the superior court for the

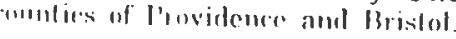

llivine uf sindion.

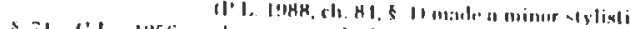

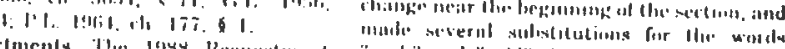

NITHES TO DERTISIONS

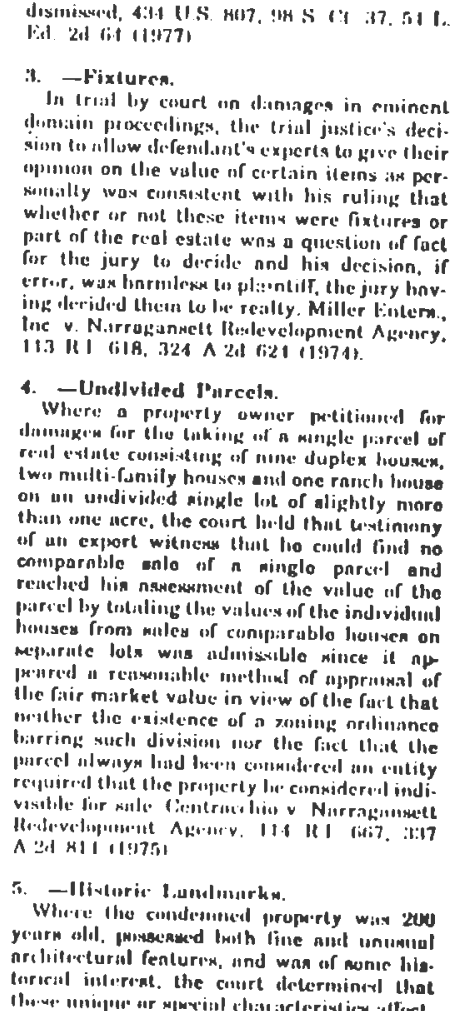
whichlly waver comsistent with his ruling that parte af the real estite way a guestion of for the jury to deride and his decision, ir

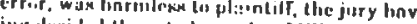
Ine $N$.

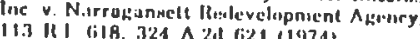
1. -Uncllvided Purcels.

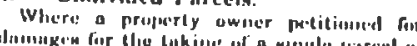

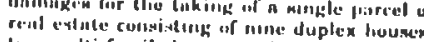

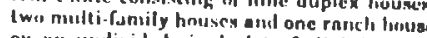
on unt utclivided ainule lot of alightly moro of un export witners that lio cuuld find no contuparatile snlo of a minglo parserel and

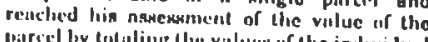

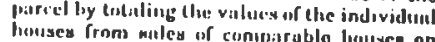
mepurrute lots wils andanissible since if

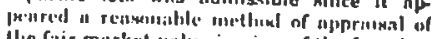
lie fair minke valo in vin"w of the fart that

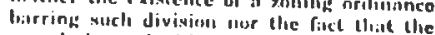

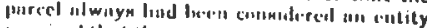

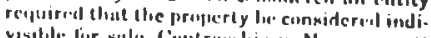

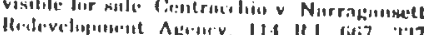
$A=1911$ 11:175

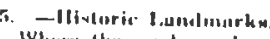

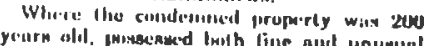

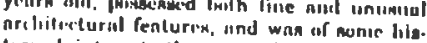

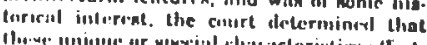

ing the value of pripperty entitlied the nwner 22ri, nppenal dismixed, 434 U.S. 807, $98 \mathrm{~S} . \mathrm{CL}$

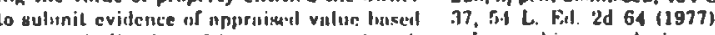

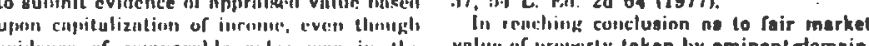

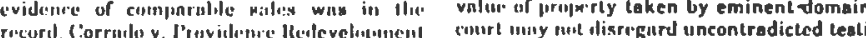

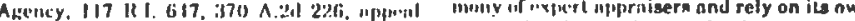

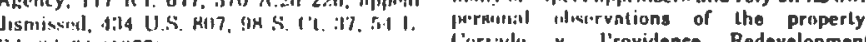

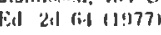

ח. Hincretion of tinurt. Carriallo, IV I'rnvidence Redevelopmen

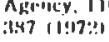

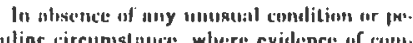
marnhlole soles uf yimitnr properties was avai

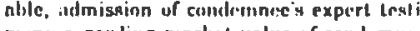
muny regarding market value of entidemined

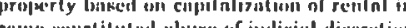

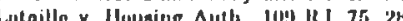
A.2d g r I 7. New Trinl.

Thist llin. court ruled a renl estate expert Clic rint calpitalizul and permitled him to use in vall turtions lur the conclemned of arriving al

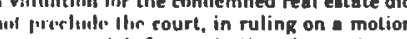

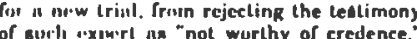

45-32-35. Representation of infants and incompetents. - If any real property, or any estille or interest therein, in which any infant or other person not cnpable in law 1 ) act in his or her own behalr is interesterl, is taken by the agency under the provisions of this chapler, the superior court, upon the filing therein of a petition by the agency or by or in helialf of the infant or person, may appoint n gunrdinn nd litem for the infant or other person. Guardians may, with the advice and consenl of the superior court and upon such terms as the supcrior courl inuy prescribe, relese to the agency all claims for dninages for the land of the infiut. or other person or for any such interest therein. Any lawfiully nipointed, qualified and acting gunrdinn or other fiduciary of the extitc of the infant or and person, with the npproval of a rourt of probate within this state having jurisdiction within thisdiction to nuthorize the snle of lands and properties of the petitiate of the infant or other persin, may before the fling suffered by the infee with the ngency upon the amount of damages real property or of his or her inlerest therein, and may, upon receiving that nmount, release to the ngency nll claims of damages of the infont or other person for the laking

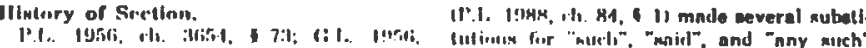
45. 12 - 125 .

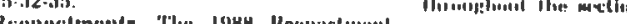

45-32-36. Unknown owners. - If nuy real property or any estate or interest therein is unclitined or beld by a person or persons whose whereabouts ane unk nuww, wher making inquiry salisfactory to the superior court for the counly in which the real property lies the agency after the expiralion w one year from the first publication

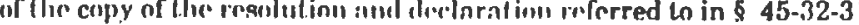


may petition the comm that the: value of the estate or interest of the unknown persem in presons be delermined. After notice by publica-

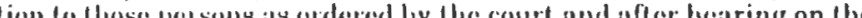

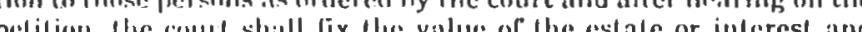

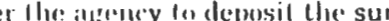

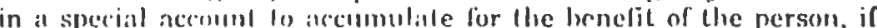

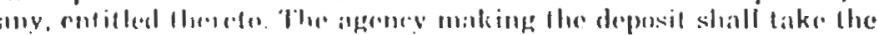

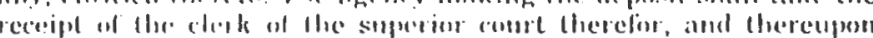
shall be discharged fiom all fiability. IVheon the person entitled to

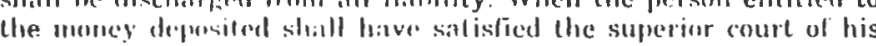
right to receive 11 . Hoe court shlall cause it to be paid over to that

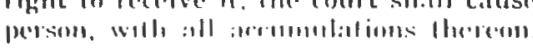

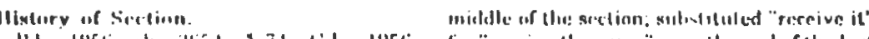

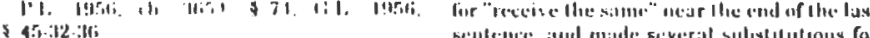

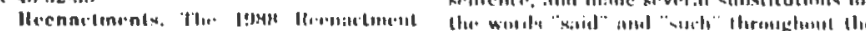

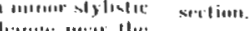

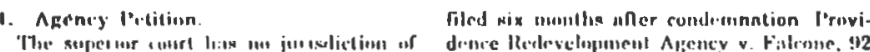

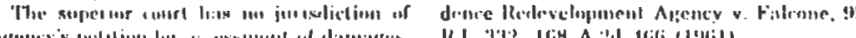

15-32-37. Immediat. paymout of compensation - Expediting procecolings. - In iny prosecrlings for the assessment of damages for real preperty sn taken by any agency the following provi-

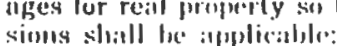

(a) Upon the: appliciltion of any party in interest and upon joinder of all other partie's in interest, the cuurt, on such cuntitions as it may of all other partie's ill imtrest, the court, on such cuntitions as it may deein proper, may orter that the noney deposited in the court, of any part thereet, be pait forthwith iwithout interest for or on accoun of the just compensation to be awarted in the proceeding. If the dainages limally al willded in respeet to the real property, or any part therent, shiall excesed llo: amsombt of the inoney so received by any

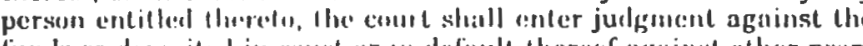
lunds so depesited in rourt or 11 defaule therees against other prop-

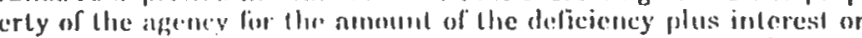
the dedicioncy and rest:: If the judgenent entered is less than the amount withdeatws, How and in that event judgment shall he en-

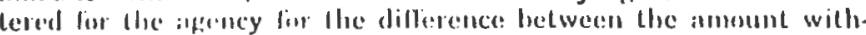

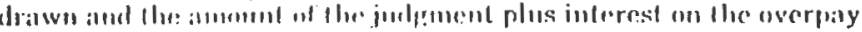
inenl and (1):

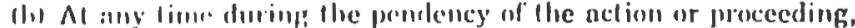

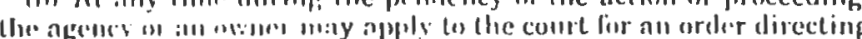

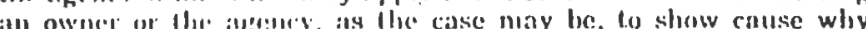

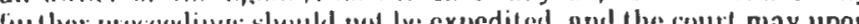
artich

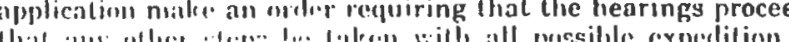

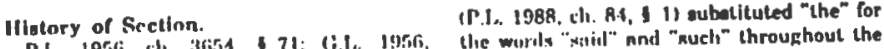

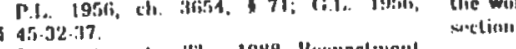

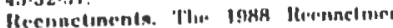

NoTES TO DFC.SISINS

1. Interest.

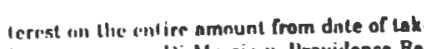

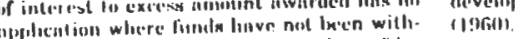

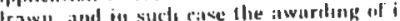

15.32-38. Orders ns to charges on lands. - The superior court shill have power to make such crilers with respect to encumbrances, liens, taxes, and other charges on the land, if any, as shall be just and equitable.

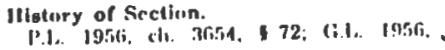

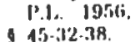

NOTES TO HECISIONS

1. In Fiennrnt. nction an which a redevelinpment agency can Althenght this mection empowern the nupe.

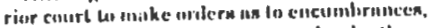

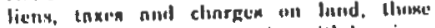
powers are hivell in conmertion with henringm

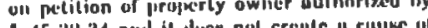

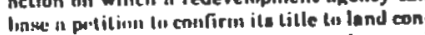

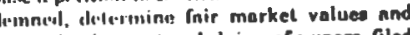
Anterinine intererel and cluims of owners, filod

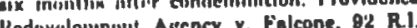

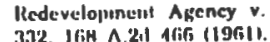

- "Owner" defined - "Owner" for the purposes of $\$ \$$ 45-32-21 to 45-32-38, inclusive, shall mean a person having an estale, interest, or easement in the real property or a lien, charge, or encumbrance thereon.

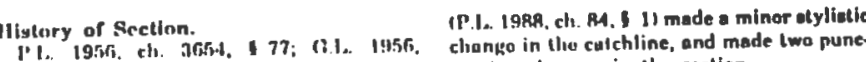

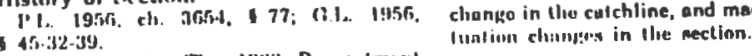

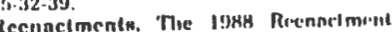

45-32-40. Traxation of real property nequired. - All real property anired by an agency fur redevelunment purposes shall be properiy miquired by an agency for redevelinment purposes shall be reil property in the community.

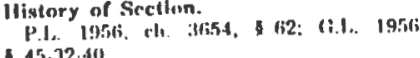


15-32-41. I'roration of property tax. - Notwithstanding the

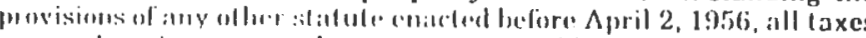

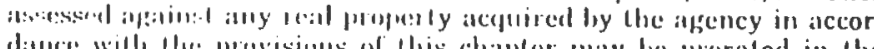

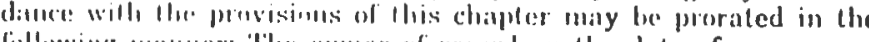

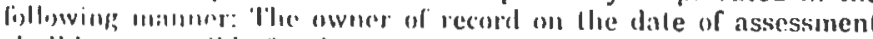
shall he: exponsilite fin the payment of those taxes from the date of

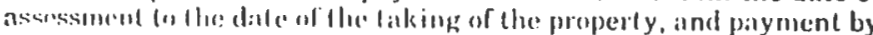

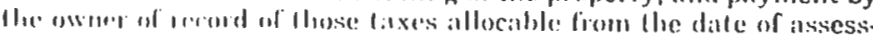
mont to the dite the angency achures the real property, plus the paryment of any other issisesment constiluting a lien on the property t:oken, shiall dischiorge and releatse the owner on the date of aserty

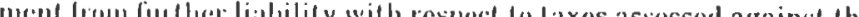

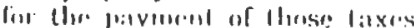

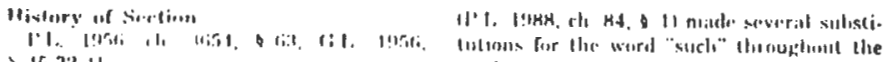
(1., 72.11

35-32-12. Conperation by pullic bodies. - (1) For the purpose of lurther aiding and comperating in any redevelopment project of an agency, any stite public hody may upon such lerms, with or without consideration, as it may determine:

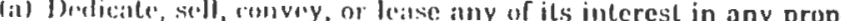

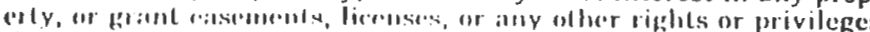

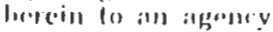

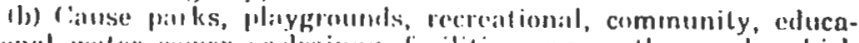

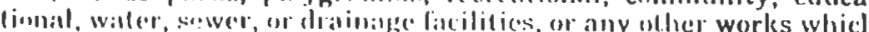

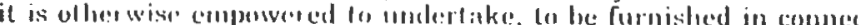
lim with a rendevelopment project:

(c) Firmish, dedicalce, cless", pave, install, grade, regrade, plan, or

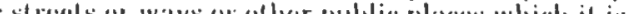
wise coupouverend to indertinke;

(d) llan or eoplan, Forly; make exceptions and variances

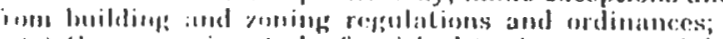

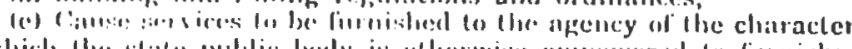

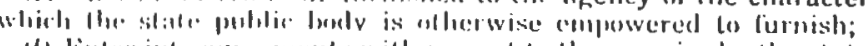

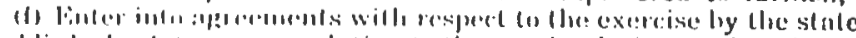

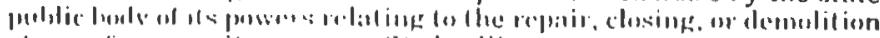

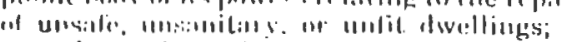

(1,) Inear the colioc .xpense of any public improvenents made by

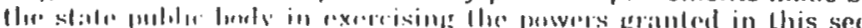

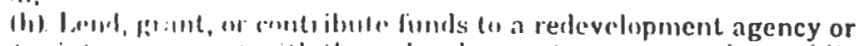

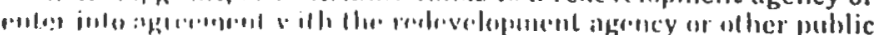

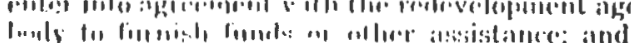

(i) Des any ared all llingen neecessiary or convenient to aid and co-

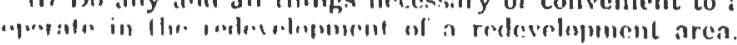

(2) Any snle, conveyance, lease, or agreement provided for in this section may be made by a state public body without appraisal, public notice, advertisement, or puhlic bidding.

Nlistery of Sirction.

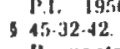

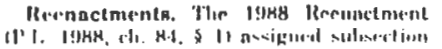

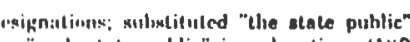

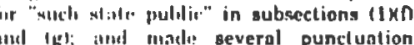

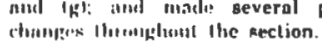

NoTIS MO MECISIONS

1. In Girnernl.

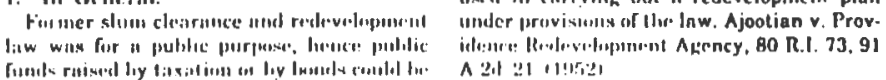

45-32-43. Formalities in letting of contracts. - All work of grading, clearing, demolition, improvement, repair, or construction of a value of more than one thousand dollars $(\$ 1,0010)$ undertaken by the agency shall be done hy contract, which shall be subject to the the agency shations and conditions of $8537-13-1$ to $37-1: 3-13$, inclusive, and additerms and conditions of $37-13-1$
tions and aniendmients therelo.

Iltetery of Soctho.

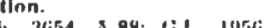

1. 4i. 32.43 .

which shall lire" for "iontract which said con.

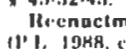

lisict sliall lice" neur the end of the meetion,

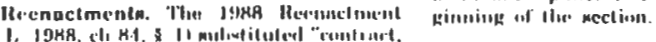

45-32-44. Compliance with federal wnge nnd hours policies. - Notwillsitanding the provisions of $\$ 45-32-43$ or any other law, the agency may agree (o) nny conditions atlached to financial assistance from the federnl goverment relnting to the determination of prevailing salaries or wages or complinnce with lahor standards, and include in any cont.ract let in connertion with a redevelopment project, stipulations jequiring that the contractor and any subcontractors comply with those conditions as (1) minimum salaries or wages and maximum liours of liabor.

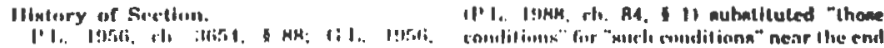
1. 4.: 12.44

15-32-45. Joint uction by different cilies and towns. - Two (2) or 2-45. Joint nction by firerent cilics and towns. - Two (2) or more com under chnplers 31 th 33 , inclusive, of this liffe und in that case the planning cornmissions, legislative bodies, and agencies may hold joint hearings and meetings, or the legislintive bodics of the communities acting separintely may each nesignite the agency of one of the communitics to act as the ngency of all thr. communities interested. 
ning commission of each community in formulating redevelopment plans. and whenever a redevelopment plan is submitled to the legis-

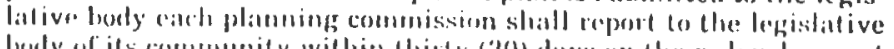

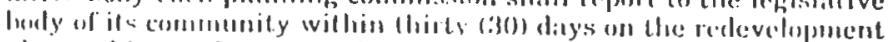

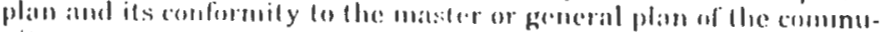
nily.

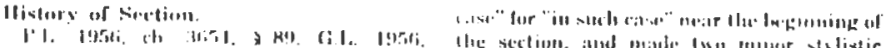

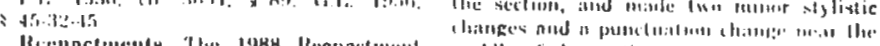

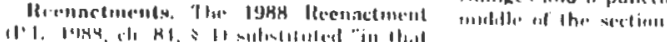
45-32-16. Consent to inclusion of arca in project of contigu.
ous city or town. - The Irgisial ive body of any community may by resolution comsent to the inclusion of a part of the areal under its

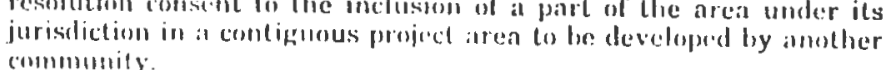

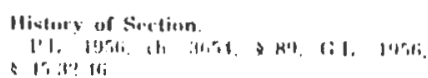

45-32-47. Continuation of prior projects. - Nolhing contained in chapters 31 (o) 33 , inclusive, of this tille, shall aflect the right of an agency to continue and carry out to completion any rede right of ton is a velopment project for which a rentevelopment phath has hecen ap-

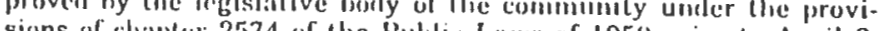
lor and to

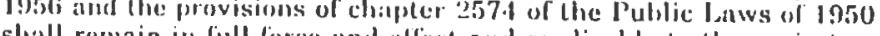
shatl remain in fill force und ellect and applicable to the pruject or projects. Nothing herein esntained shall anect the rights of any per-

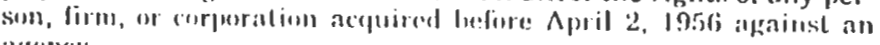
ilenency.

Ilistory of sirction

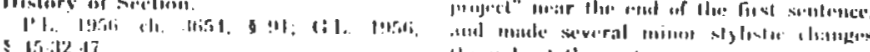

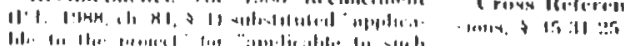

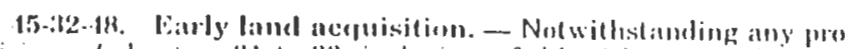

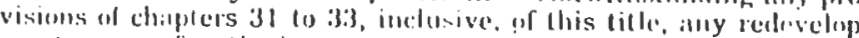

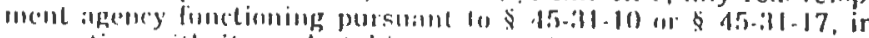

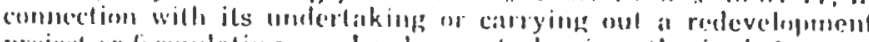

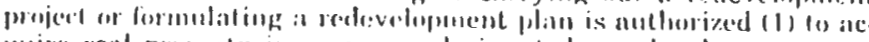

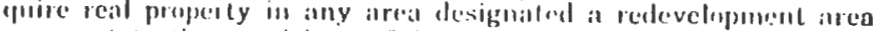
puistlant fo lles provisions of $\$ 45-32-1$, demolists of remove the structures ont the propicrly, provide for relicalion of occupants, including the paryment of such sumss for relnciltion nexpenses to the

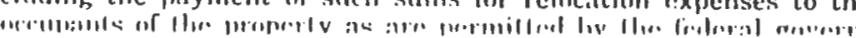

ment (notivithstunding the limitation in amount imposed by $\$ 45-31-27$, and to clear and improve the property, regardless of the stage of development of the redevelopinent project or plan or any stanclicicaliun of the uline for thit area or any portions or any wher it he befire or after the approval of the portan (i) guired under this section without regard to the provisions of chap lars 31 Lo 33, inclusive, "f this tille, for the disposition of property in a project. nrea. Any sile or lease of the property may be made with out public liddling, provided, lowever, that no sale or lease shall be male until at least cen (10) days after the legislative body of the community has received from the agency a report concerning the proposed sale or lease and hats approved llie same by resolution. Any such agency mily enter inlo a contract or contracts with private financial instilutiuns and/or will, the federal government for the purpose of obtaining financial or lechnical assistance in connection with the atioredescribed acyuisition, demolition, clearance, reloca tion, and improvement and may lorrow, at such interest rates and ou such other torms and condilions as it muy deem proper, from proper, from those privnla fintmelat instilution or the fedoral government, sums necessary thr lhe ncquisiticut expenses, the manngennent of the real properly. the relocation of the occupants of the real property, the demolition of the buildings or structures and the clearance of and implovement of the land and real property so acquired, and other related administrative costs and payments. Any ufency may, on such terms and conditions as it may deem proper, mortgage or olherwise encumber the property so acquired, or any other properly owned by it for the purpose or purposes of sccuring the repayment of sny inoney horrowed to carry out the aliormentimed undertaking.

Ilistory of Sientisn.

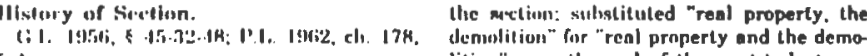
1.

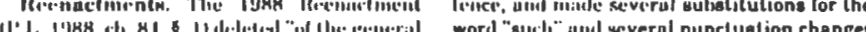

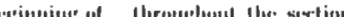
15.32-4!). Cilnrantec of community. - Any community, for the parpose of aiding inl he undertakillgs nuthorized by 45-32-48, not-
willistanding any other provisions of the general laws, shall have willstanding iny other provisions of the general laws, shall have lle power ind rifht lo assime the responsibility for and to guaranlec repiyment of muy loan made (o an agency by private financial inslif utions or the federal gaverminent on such ternos and conditions as il may deem moper nonl to bear any loss which may arise as the result of the acyuisition of the real property, sll administrative costs and other paymenty relating thereto, including the managemen thereor, the actunl sums disburserl to the occupants thereof for relo

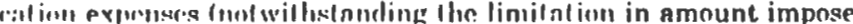


y $\$ 45-11-27)$, the demolition and removal of buildings or strucires on the real moperly, and the clearance and improvement of the and sor acquired, in the event the redevelopment plan for the project s unt apmoved or is amended to omit any or all such property, or is iloudoned for any reason. No such guarantee or responsibility shall wexccuted or ascimbed by any conmunity until the legislative hody if the comminily" shall have passecl an ordinance specilically authoiring the same. Beforr passing such an ordinance, the legishative mety of the community or the commillee thereof to which the promind ordinance has been referred shall hold a public hearing afer iving notice uf the date limue place and purpose thereor. The no-

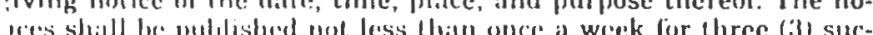
-

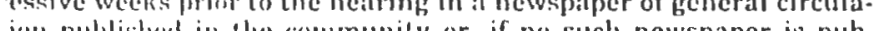
is her in a corculation in he enter inter-

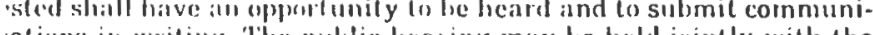
ne rearing required under $\$ 15-32-4$ ind $/$ or with the hearing required moler $\$ 15.32-11$ if the legislative body so directs.

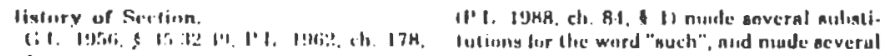

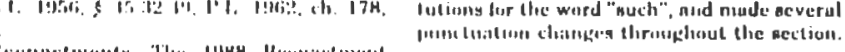

(:HAPIEIR 32.1

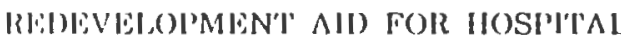
ANI) EUIICATIONAI, PURIOSBS

\section{a.ting

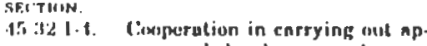

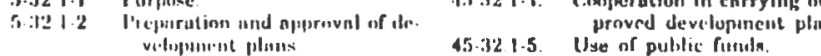

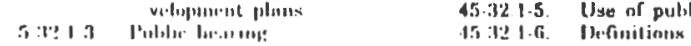

15-32.1-1. I'urposse. - T'he purnose of this chapler is to assist iny municipality in this state or any redevelopment afency created

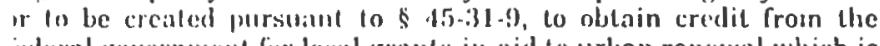
ideval government for lowal grants-in-aid to urban renewal which is

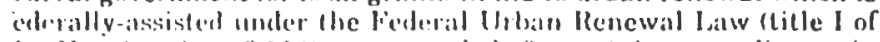

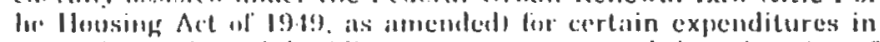
onneclions wilh linde, buildings, or structures fand the relocition of (copants) willin, adjiacrnt to, or in the immediate vicinity of, a

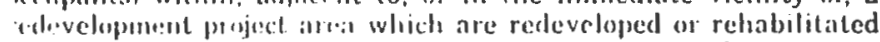
in erlucational on hespitial use in accordance with a redevelopment sall or a develupment plinn acceptable to the United States of Amer(it or department. agency, or inst rumentality thereof after consider-

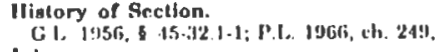

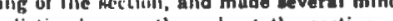
1.

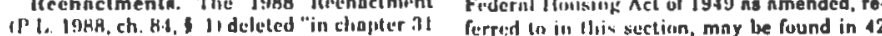
of this tille, entilled liedtevelupment aten.

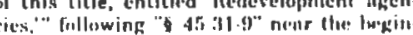

45-32.1-2. Preparation and approval of development plans. - The legislative body of any conmunily is authorized to approve after a public hearing a development plan proposed by an educational institution of higher learning, hospital, private redevelopment corporation, municipal or olher pulslic corporation, or authorityent corporation, municipal or other pulsic corporation, or authority established hy the state of hinde stand or the retevelopment and renewal of an area within, atdjucent (1), or in the immediate vicinity of the area of a redevelopnent pminect nsuisted by the federal government under tille $I$ of the Housing $A c l$ of 1949, as amended which is being undertaken by a redevelopment agency or by any city or town in this state. An educutional institution of higher learning, a hospital, private redevelopment coiporation, municipal or other public corporation, or any authority established hy the state is authorized to prepare a development plan. Any siale public body may authorize any erlucational institution of higher learning or hospital established and maintained by the stale pmlilic lody to prepare a development plan.

Ferderal Aets Heferenecm. Title 1 of the is.

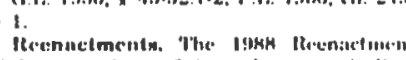

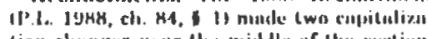

Finderul Iloniming Act ur 1944 at amended, ro furred in in this kertions, muay be found in 42

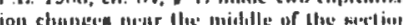

45-32.1-3. Public hearing. - (in) Prior (n approval of a development plan by the legislative body pursuant $L_{1} \$ 45-32.1-2$, the legislative body of the community or the comminttee thereof to which the plan has been referred shall hold a public hearing on the developinent plan. "l'he public hearing shall be hefh not more than sixty $(60)$ days after receipt hy the legisiative body of the dovelopment plan.

(b) Nolice of the time, place, and purpose of the hearing shall be given by publication not less thim once a werk forr three (3) successive weeks prior to the henring in at newspanper of general circulation publisted in the community, or if no such nesvipaper is published in

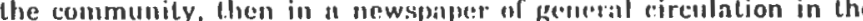
community. 1 .

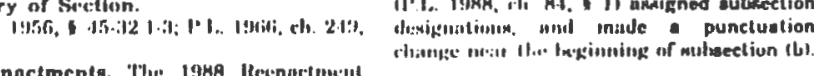

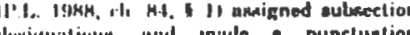

